
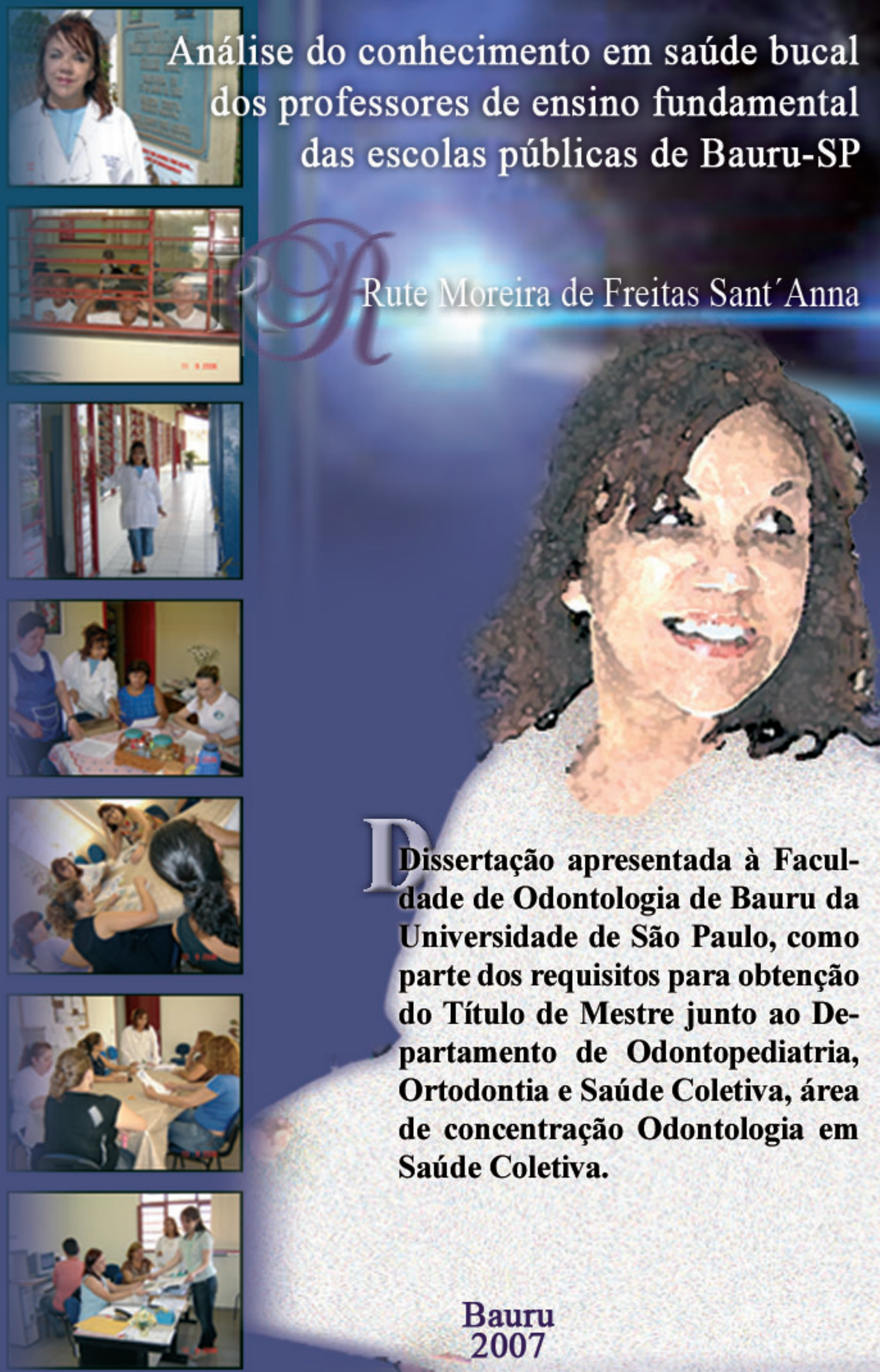


\section{Análise do conhecimento em saúde bucal dos professores de ensino fundamental das escolas públicas de Bauru-SP}

Rute Moreira de Freitas Sant' Anna

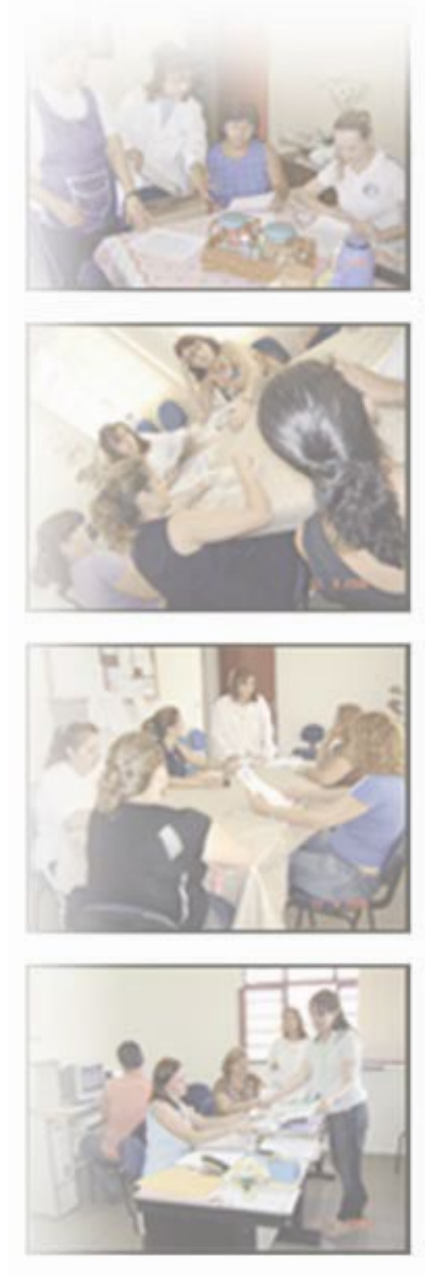

Dissertação apresentada à Faculdade de Odontologia de Bauru da Universidade de São Paulo, como parte dos requisitos para obtenção do Título de Mestre junto ao Departamento de Odontopediatria, Ortodontia e Saúde Coletiva, área de concentração Odontologia em Saúde Coletiva.

Orientador

Prof. Dr. José Roberto Pereira Lauris 
Sant'Anna, Rute Moreira de Freitas

Sa59a Análise do conhecimento em saúde bucal dos professores de ensino fundamental das escolas públicas de Bauru-SP / Rute Moreira de Freitas Sant'Anna - Bauru, 2007. xxvii.;198p.; il.; $30 \mathrm{~cm}$.

Dissertação (Mestrado) -- $\quad$ Faculdade de Odontologia de Bauru.Universidade de São Paulo.

Orientador: Prof. Dr José Roberto Pereira Lauris

Autorizo, exclusivamente pra fins acadêmicos e científicos, a reprodução total ou parcial desta tese, por processos fotocopiadores e/ou eletrônicos.

Rute Moreira de Freitas Sant'Anna

Bauru, 12007.

Comitê de ética da FOB-USP

Protocolo $n^{\circ} 82 / 2005$.

Data: 09/2004 


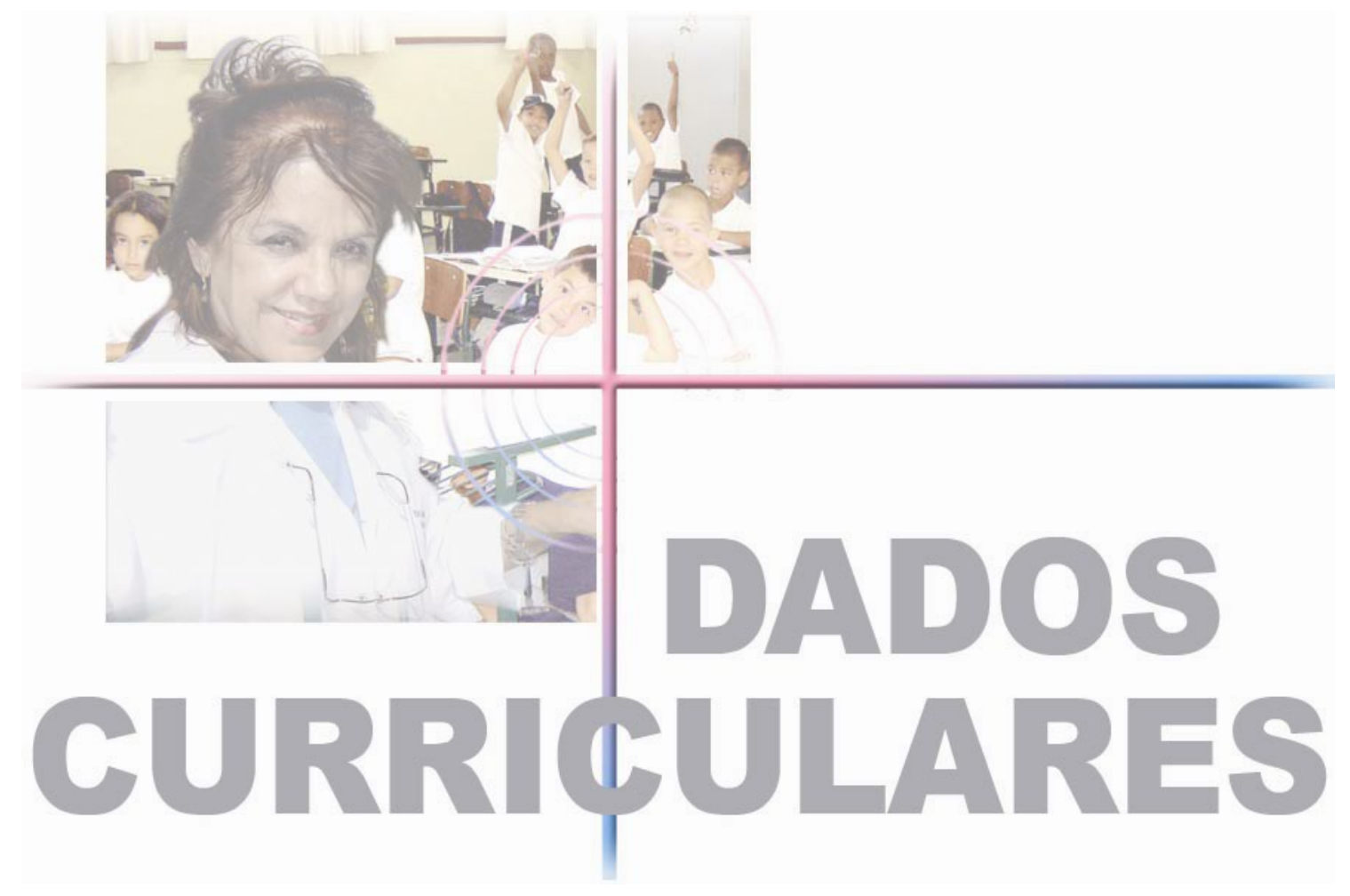

DADOS CURRICULARES 


\section{Nome : Rute Moreira de Freitas Sant Anna \\ Nome em citações bibliográficas: SANT'ANNA, R M F.}

Nascimento: 05/06/1946, Pirajuí/SP-Brasil.

Endereço : Rua Rubens Arruda n. 18-29

Jardim Estoril

CEP: 17016-040, Baur-SP-Brasil

E-mail: rute_santana@hotmail.com

URL da home page: http://

\section{Formação acadêmica e profissional}

\section{Graduação em Odontologia pela Faculdade de Odontologia-USP- Bauru} Ano de 1977.

Especialização em Odontopediatria, no ano de 1980, carga horária 540 hs, pela Sociedade de Promoção Social do Fissurado Lábio Palatal, PROFIS, São Paulo, Brasil.

Especialização em Saúde Pública, no ano de 1985, carga horária 548 hs, pelo Centro São Camilo de Desenvolvimento em Administração da Saúde , CSC, São Paulo, Brasil.

Especializacão em Dentística Operatória, no ano de 1998 -2000, carga horária 728 hs, no Hospital de Reabilitação de Anomalias Craniofaciais, HRAC-USP,São Paulo, Brasil.

Título da monografia: Avaliação bacteriológica do biofilme formado em equipos odontológicos. Ano de finalização :2000.

Orientador: Prof. Dr. Aparício Fiúza de Carvalho Dekon.

Especialização em Radiologia Odontológica, no ano de 2000 -2002, carga horária 728 hs, no Hospital de Reabilitação de Anomalias Craniofaciais, HRAC-USP, São Paulo, Brasil.

Título da monografia: Avaliação radiográfica morfodimensional da área de fissura em imagens ortopantomográficas: Ano de finalização 2002.

Orientador: Izabel Maria Marchi de Carvalho.

Especialização em Odontologia em Saúde Coletiva, no ano de 2003-2004 Associação Paulista de Cirurgiões Dentistas- Regional Bauru.

Título da monografia: Síndrome de Ardência Bucal. Ano de finalização:2004.

Orientador: Prof. Dr. Luis Eduardo M Chinelatto.

Mestrado em Saúde Coletiva, no ano de 2005-2007. Faculdade de Odontologia de Bauru-USP - Bauru.

Título da dissertação: Análise do conhecimento em Saúde Bucal, dos professores de ensino fundamental das escolas públicas de Bauru.

Orientador: Prof. Dr. José Roberto Pereira Lauris.

Funcionária Pública Municipal; ingresso por concurso público em 1984, até o momento, lotada na Equipe de Cirurgiões Dentistas do Pronto Socorro Odontológico do Departamento de Urgência e Emergência da Secretaria Municipal de Saúde Bauru SP. 


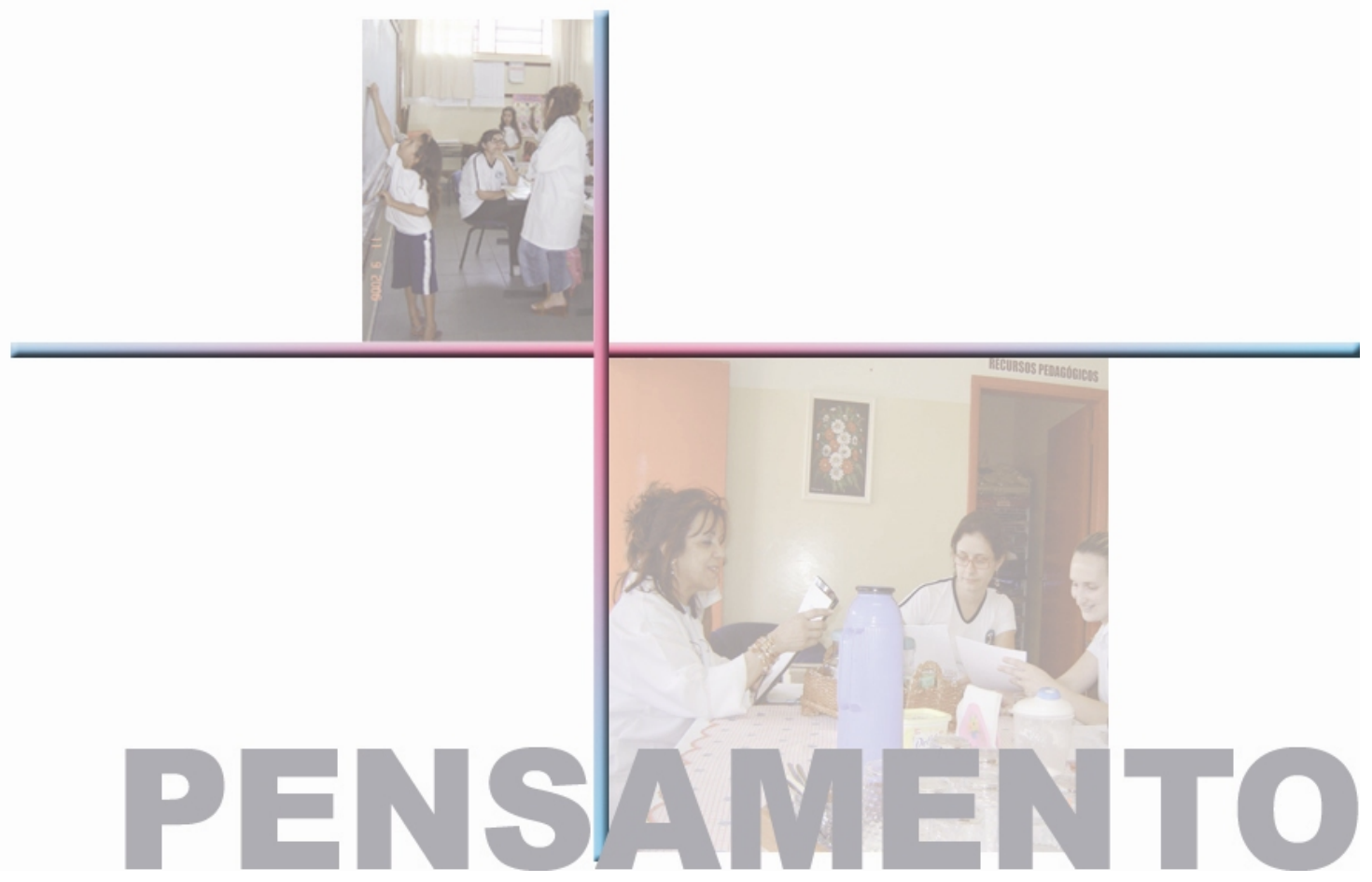

PENSAMENTO 


\section{PENSAMENTO}

Não basta ter belos sonhos para realizá-los. Pois ninguém realiza grandes obras se não for capaz de sonhar grande. Podemos mudar nosso destino se nos dedicarmos à luta pela realização de nossos ideais. É preciso sonhar, mas com a condição de crer em nosso sonho, de encaminhar com atenção a vida real, de confrontar nossa observação com nosso sonho, de realizar escrupulosamente nossa fantasia, sonhos.

Acredite neles.

\section{LENIN}




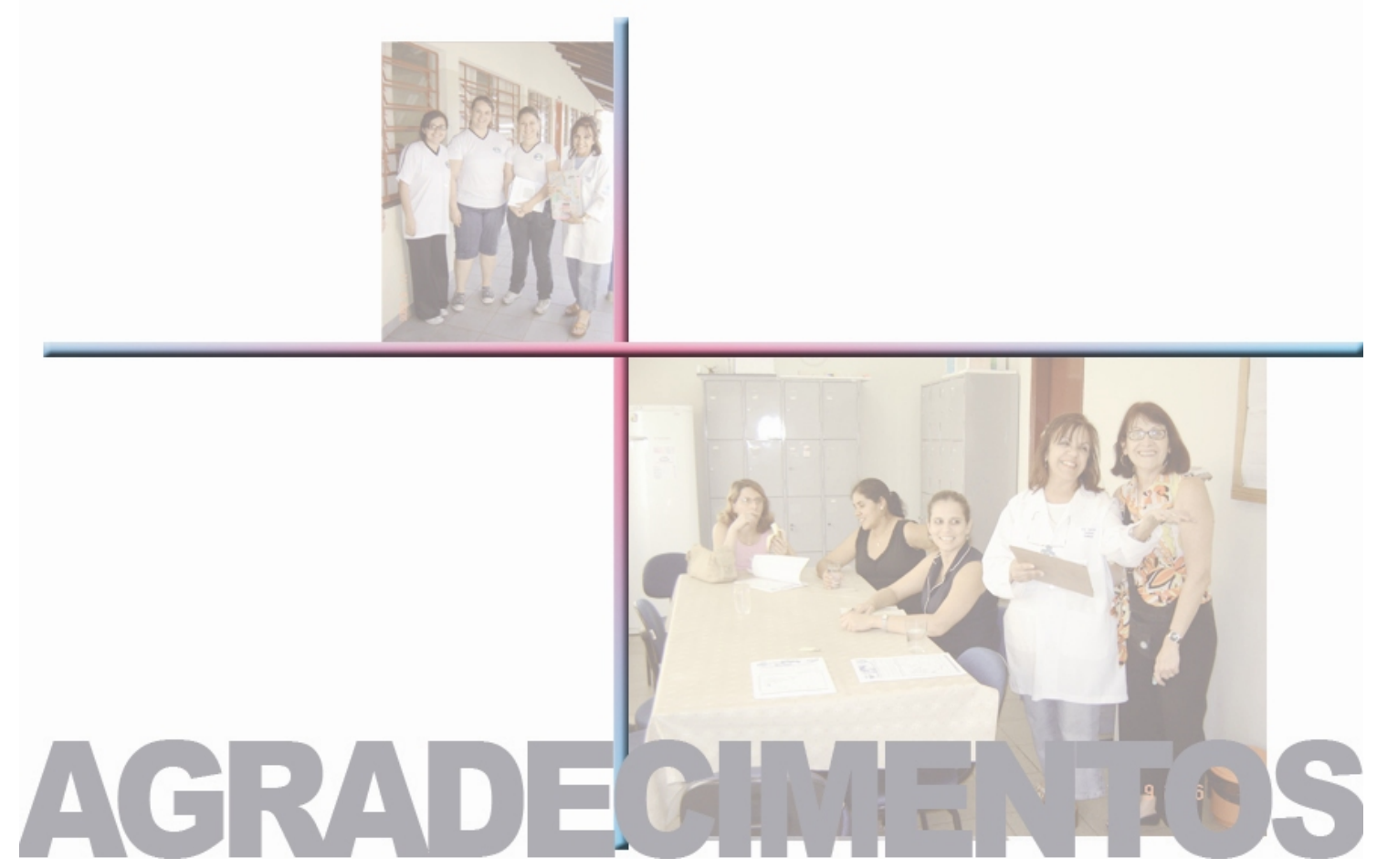

AGRADECIMENTOS 


\section{AGRADECIMENTOS:}

Obrigada ao nosso pai celestial por ter permitido que chegássemos até aqui.

E como diz o salmista:

"Grandes coisas fez o Senhor por nós e por isso estamos alegres".

Salmos 126, versículo 3. 


\section{AGRADECIMENTOS:}

A todos os professores das escolas públicas que participaram e cooperaram nesta pesquisa, para sua concretização. Estendemos esse agradecimento também a todas as diretoras e coordenadoras pedagógicas, por nos ter recebido sempre alegres em suas escolas, e que pela sua permissão e interesse participaram também na realização da pesquisa.

As Instituições Secretaria Municipal de Educação e Delegacia Regional de Ensino, que abriram suas portas aceitando e autorizando a realização do trabalho.

A esta imponente Faculdade de Odontologia da Universidade de São Paulo, na pessoa do Sr. Diretor Prof. Dr. Luis Fernando Pegoraro, e também ao Sr Prefeito do Campus Bauru, Prof. Dr. José Roberto Magalhães Bastos.

A todos os nossos professores desta casa de ensino, desde os tempos da graduação até hoje na pós-graduação. 


\section{AGRADECIMENTOS:}

Ao nosso orientador neste curso de mestrado, Professor Dr. José Roberto Pereira Lauris. Sempre educado, paciente, competente, nunca mau humorado. Um professor exemplo para seus alunos.

Obrigado mestre, por nos ter acompanhado nesta luta. E sem querer desmerecer outros tantos bons professores orientadores que tivemos aqui e em outras Instituições, afirmamos: "Ele é o melhor orientador da Faculdade".

Ao professor Dr. José Roberto Magalhães Bastos, grande mestre na Odontologia brasileira, uma memória fantástica, marcante, admirável. Sempre esteve presente em momentos importantes nesta luta profissional e acadêmica da nossa vida. Foi nosso professor na graduação 1976 na FOB, fez parte da banca examinadora no Concurso para Prefeitura Municipal em 1984 quando ingressamos, nosso professor no Curso de Especialização em Saúde Coletiva 2004 a 2004 na APCD-Bauru, por 2 vezes fez parte da banca examinadora no concurso de Mestrado em 2002 e 2004 na FOB, nosso 
professor no programa de mestrado 2005-2007 na FOB. Obrigada pela oportunidade, obrigada pelos ensinamentos e por apoiar, incentivar e acreditar nos sonhos de seus alunos.

Ao professor Arsenio Sales Peres e à professora Silvia Helena Carvalho Sales Peres, nossos queridos professores, do curso de Especialização em Saúde Coletiva 2003 a 2004, e nossos queridos professores no programa de pós-graduação do curso de mestrado na FOB 2005 a 2007. Grandes companheiros e grandes orientadores, sempre presentes em todos os eventos científico-culturais nacionais, acompanhando os alunos. Obrigada pela amizade e alegria contagiante da nossa convivência no ambiente acadêmico, obrigada pelas oportunidades, pelo incentivo e por acreditar no nosso sonho.

A todos os funcionários do Departamento de Saúde Coletiva: Silvia, Rosa, Helena, Marta, Milton, e também a todos da Biblioteca, em especial Valéria, Rita, Ademir. Aos funcionários da pós-graduação, do Centro Cultural e outros tantos mais, que sempre nos dão a mão, uma retaguarda, uma ajuda incondicional. 


\section{AGRADECIMENTOS:}

Obrigada a todos os queridos colegas do curso de mestrado, pela amizade, pela alegria da convivência esses anos, pelo frescor empolgante de suas juventudes. Agradecimento especial a Suzana Goya. Grande companheira, amiga, muito inteligente, competente, incentivadora, prestativa, cheias de sonhos contagiantes, sempre bem humorada.

Ao Sérgio, sempre solícito, companheiro, amigo, ao Henrique, obrigada por estarmos juntos desde a especialização em Saúde Coletiva.

A Juliana Julianelli, amiga e grande companheira do curso de especialização. A Tatiane, muito dedicada, amiga, inteligente, competente, prestativa, responsável. Lembramos também do Ismar, Ricardo, Gustavo, Fernando, Agnes e Tieme. Gostaria de ter um pouco das qualidades de cada um deles. 


\section{AGRADECIMENTOS:}

Agradecimento muito especial a todos companheiros e à todas as auxiliares do Pronto Socorro Odontológico Central, onde trabalhamos há 22 anos.Obrigada às chefias que tivemos durante esta jornada, Dra.Lucia, Dra Telma, Dra Leia, pela compreensão das necessidades acadêmicas, possibilitado mudanças em horários já escalados.

Aos colegas de trabalho Telma, Clovis, Celso, Lucia, Márcia, Miriam, Leia, Villaça, Alexandre, Silvia, Maria Luisa, Sônia, e outros que às vezes estão conosco. Obrigada pelo companheirismo, compreensão, amizade e gentilezas na disponibilidade de seus horários, nos facilitando os compromissos acadêmicos esses anos todos. 


\section{AGRADECIMENTOS:}

Aos meus familiares, mãe, minha irmã Débora e cunhado Ilton, que sempre oram pedindo a Deus por nós, obrigada pelo apoio e pelo ombro para chorar às vezes.

Aos meus filhos, Arnaldinho e Carol, Gustavo e Juliana, Carlos Augusto e Ashley, Patrícia e Vandrey e também meu marido Arnaldo.

Obrigada pela paciência e pelo incentivo. Obrigada por me aceitarem como sou, e por compreenderem porque não me dediquei totalmente a eles em todos os momentos como devia, durante todos esse anos de dedicação ao trabalho e aos estudos.

A minha filha Patrícia, amiga, sempre disposta a dar um apoio, companheira em muitos momentos do desenvolvimento da nossa pesquisa pelas escolas distantes na cidade. 
A minha nora Juliana Bosco, pela sua grande ajuda e socorro nas muitas dificuldades de informática quando surgiam, tanto da monografia quanto da dissertação. Obrigada por tudo.

Obrigada a todos os amigos, que são tão importantes nas nossas vidas, nos acalentando e encorajando em muitos momentos. 


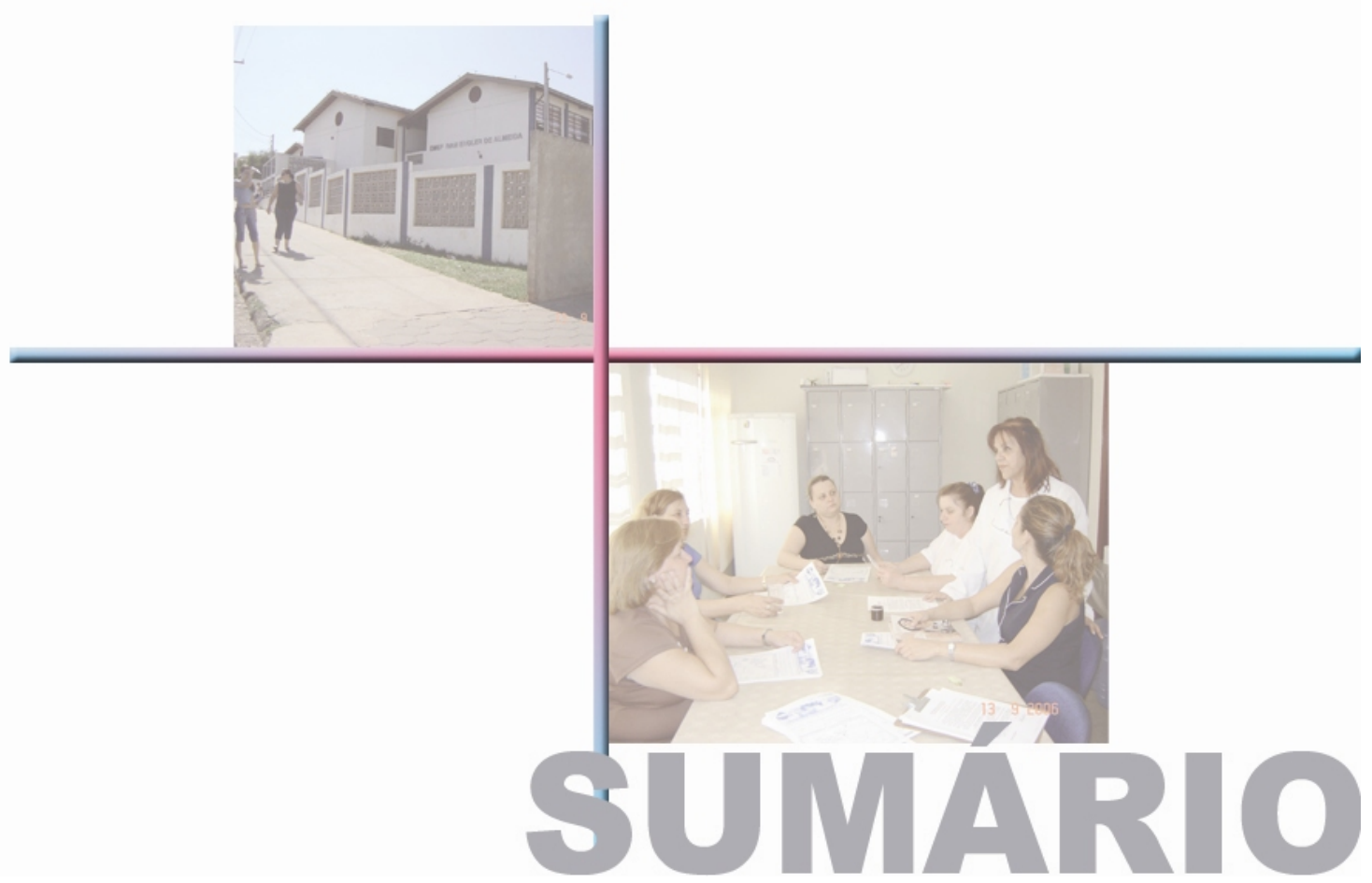

SUMÁRIO 


\section{SUMÁRIO}

LISTA DE TABELAS E FIGURAS Xix

\begin{tabular}{l|l} 
LISTA DE ABREVIATURAS & xxiii
\end{tabular}

RESUMO $\quad$ XXV

\begin{tabular}{l|l}
1 - INTRODUÇÃO & 1
\end{tabular}

$\begin{array}{ll}2 \text { - REVISÃO DA LITERATURA } & 7\end{array}$

2.1- Educação. $\quad 9$

2. 2 - Educação e saúde. 14

\begin{tabular}{l|l}
2.3 - Saúde na escola. & 26
\end{tabular}

2.4 - O professor e o sistema educacional.

2.5 - Saúde bucal. $\quad 48$

3 - PROPOSIÇÃO 63

\begin{tabular}{l|l}
3.1 - Objetivos Gerais. & 65
\end{tabular}

3.2 - Objetivos específicos. $\quad 65$

\begin{tabular}{l|l}
\hline 4 - MATERIAIS E MÉTODOS & 67
\end{tabular}

$\begin{array}{ll}5 \text { - RESULTADOS } & 75\end{array}$

\begin{tabular}{l|l}
5.1 - Caracterização da amostra... & 77
\end{tabular}

5.2 - Comportamento e atitudes em saúde bucal. 81

\begin{tabular}{l|l}
5.3 - Conhecimentos em Saúde Bucal. & 84
\end{tabular}

5.4 - Conceituações etiológicas e preventivas de doenças bucais. $\quad 89$

5.5 - Conhecimento das medidas preventivas em saúde bucal. 92

5.6 - Existência de manual de saúde geral e saúde bucal na escola. 98 
5.7 - Conhecimento sobre traumatismo dental.

6 - DISCUSSÃO.

6.1 - Caracterização da amostra.

6.2 - Comportamentos e Atitudes em saúde bucal.

6.3 - Conhecimentos em Saúde Bucal.

6.4 - Conceituações etiológicas e preventivas das doenças bucais.

6.5 - Conhecimento das medidas preventivas em Saúde Bucal.

6.6 - Conhecimento da existência de Manual de Saúde Geral e Bucal na escola.

7 - CONCLUSÕES 


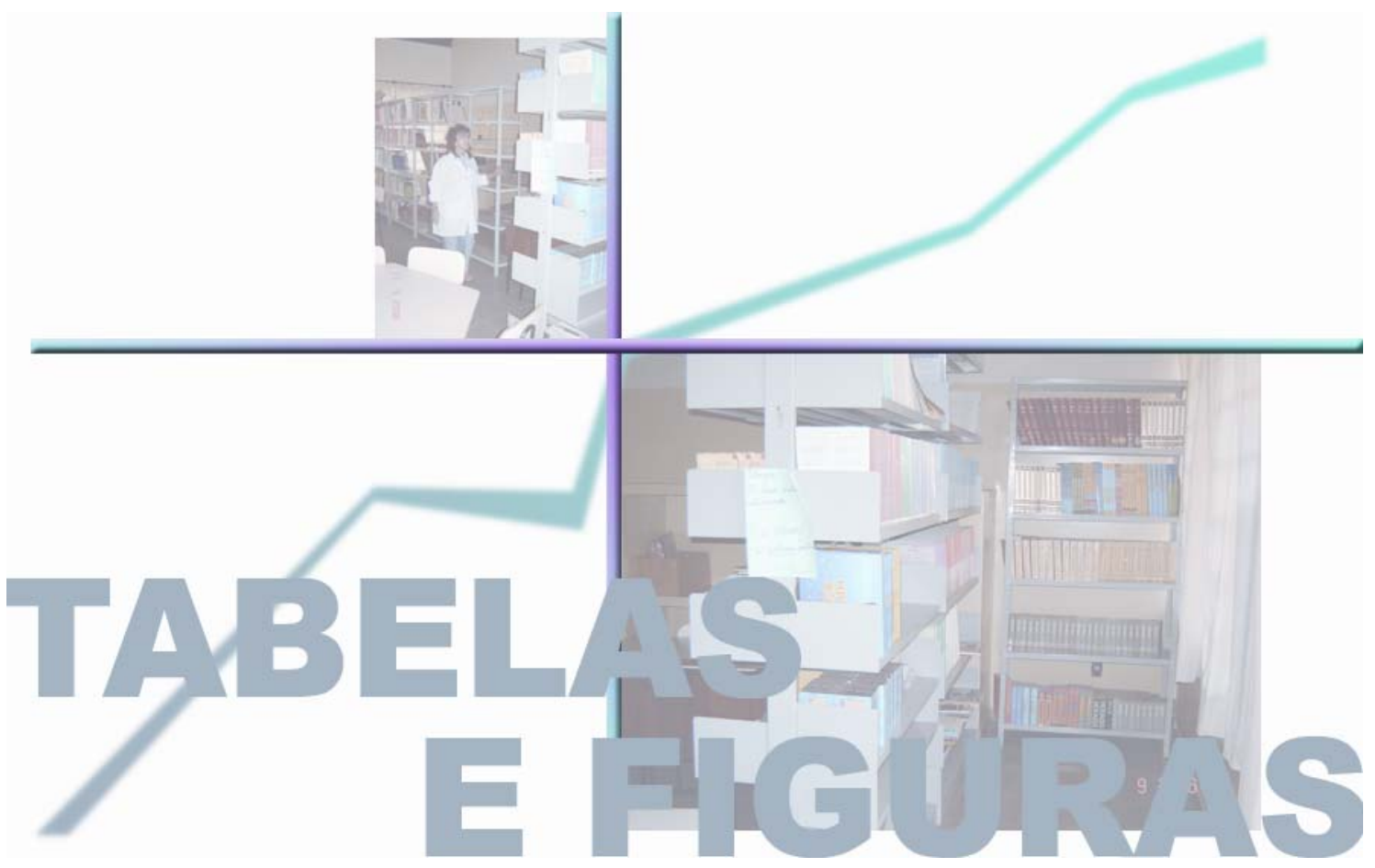

TABELAS E FIGURAS 


\section{LISTA DE TABELAS}

TABELA

PÁG

Tabela 1 - Número de professores pesquisados

Tabela 2 - Número de professores na rede pública do município de Bauru

Tabela 3 - Número de professores por gênero

Tabela 4 - Número de professores por faixa etária

Tabela 5 - Número de professores por tempo de serviço

Tabela 6 - Classificação da renda familiar

Tabela 7 - Número de professores por nível de escolaridade

Tabela 8 - Tempo de troca das escovas de dentes

Tabela 9 - Levar a escova de dentes para o trabalho

Tabela 10 - Características das escovas dentárias

Tabela 11 - Abordagem do tema saúde geral em sala de aula

Tabela 12 - Abordagem do tema saúde bucal em sala de aula

Tabela 13 - Orientações sobre higiene bucal realizadas em sala de aula.

Tabela 14 - Orientações sobre higiene bucal realizadas por outro profissional.

Tabela 15 - Origem do conhecimento em saúde bucal

Tabela 16 - Porcentagem do tipo de treinamento que os professores participaram bucal 
Tabela 19 - Conhecimento do local onde se encontra flúor segundo professores pesquisados

Tabela 20 - Locais onde se encontra o flúor de acordo com os professores pesquisados

Tabela 21 - Funções do fio dental segundo professores pesquisados

Tabela 22 - Tipos de socorro segundo professores pesquisados 


\section{LISTA DE FIGURAS}

Figura 1 - Mapa da cidade de Bauru, com localização das escolas públicas

pesquisadas

Figura 2 - Número de escovação por dia

Figura 3 - Professores que participaram de treinamento sobre saúde bucal

Figura 4 - Porcentagem de professores que conhecem a doença periodontal

Figura 5 - Porcentagem de professores que sabem evitar a doença periodontal

Figura 6 -Formas de evitar a doença periodontal segundo professores pesquisados

Figura 7 - Conhecimento sobre as funções do flúor

Figura 8 - Porcentagem de professores que fazem uso do fio dental

Figura 9 - Porcentagem de professores pesquisados que conheciam selante

Figura 10 - Explicação sobre a finalidade selante segundo professores pesquisados

Figura 11 - Conhecimento sobre a existência de manual de promoção de saúde geral segundo professores pesquisados

Figura 12- Conhecimento sobre a existência de manual de promoção de saúde bucal 100 segundo professores pesquisados

Figura 13 - Socorrer traumatismo dental segundo professores pesquisados.

Figura 14 - Tipos de líquidos para armazenar dentes avulsionados segundo 102 professores pesquisados 


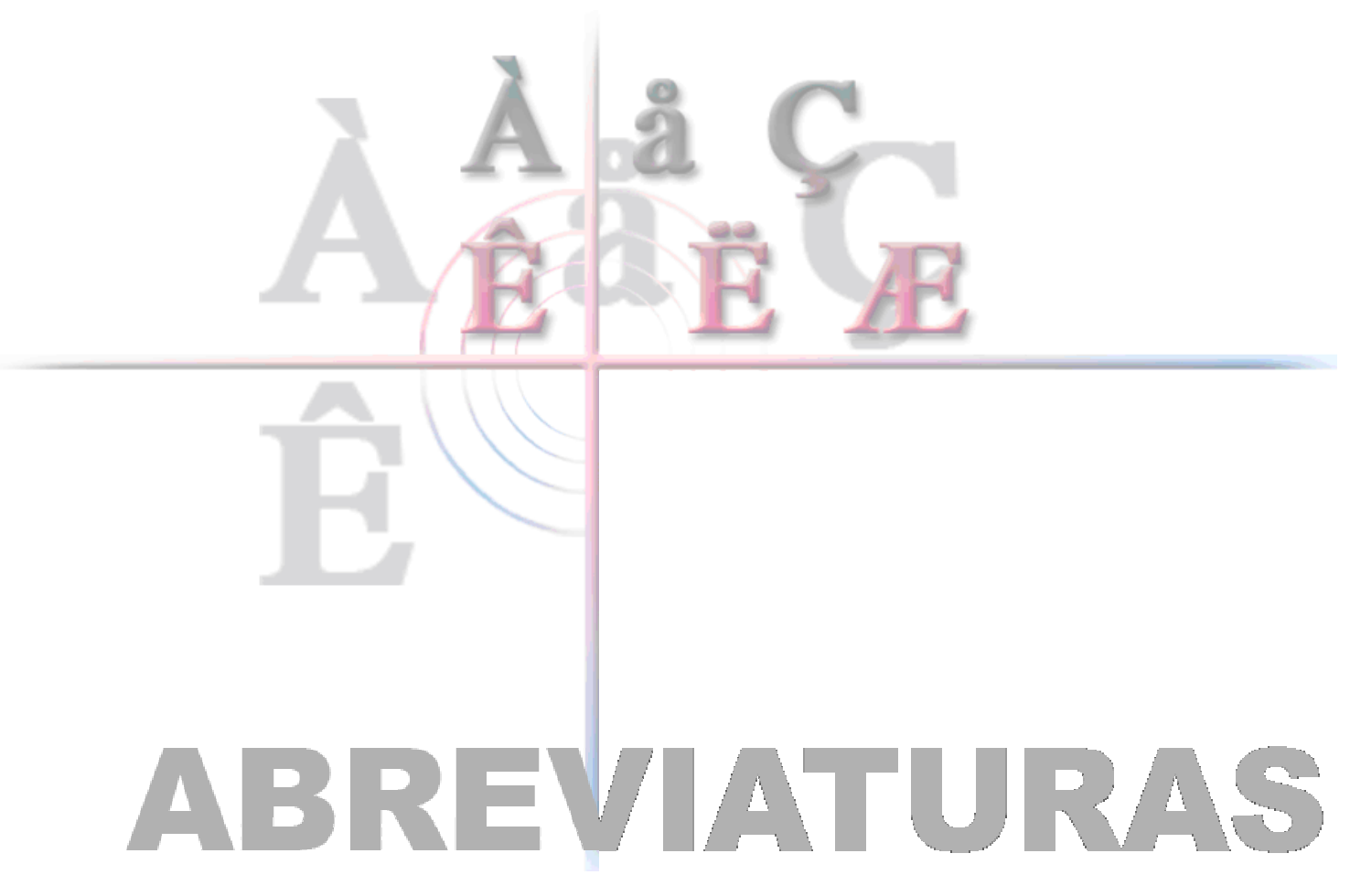

ABREVIATURAS 


\section{LISTA ABREVIATURAS}

\begin{tabular}{|r|l|}
\hline Abreviatura & Significado \\
\hline AIDS & Síndrome de deficiência imunológica adquirida \\
\hline CPOD & Dente cariado, perdido, obturado \\
\hline DAE & Departamento de Água e Esgoto \\
\hline DST & Doença sexualmente transmissível \\
\hline INEP-MEC & $\begin{array}{l}\text { Instituto Nacional de estatística e Pesquisa Educacional do } \\
\text { Ministério da Educação }\end{array}$ \\
\hline LDB & Lei de Diretrizes e Bases da Educação \\
\hline MEC & Ministério da Educação \\
\hline OMS & Organização Mundial de Saúde \\
\hline UNESCO & United Nations Educacional, Cientific Cultural Organization \\
\hline PHP & Perfomance Higienic Pacient \\
\hline PS & Pronto Socorro \\
\hline PSF & Programa de Saúde da Família \\
\hline &
\end{tabular}




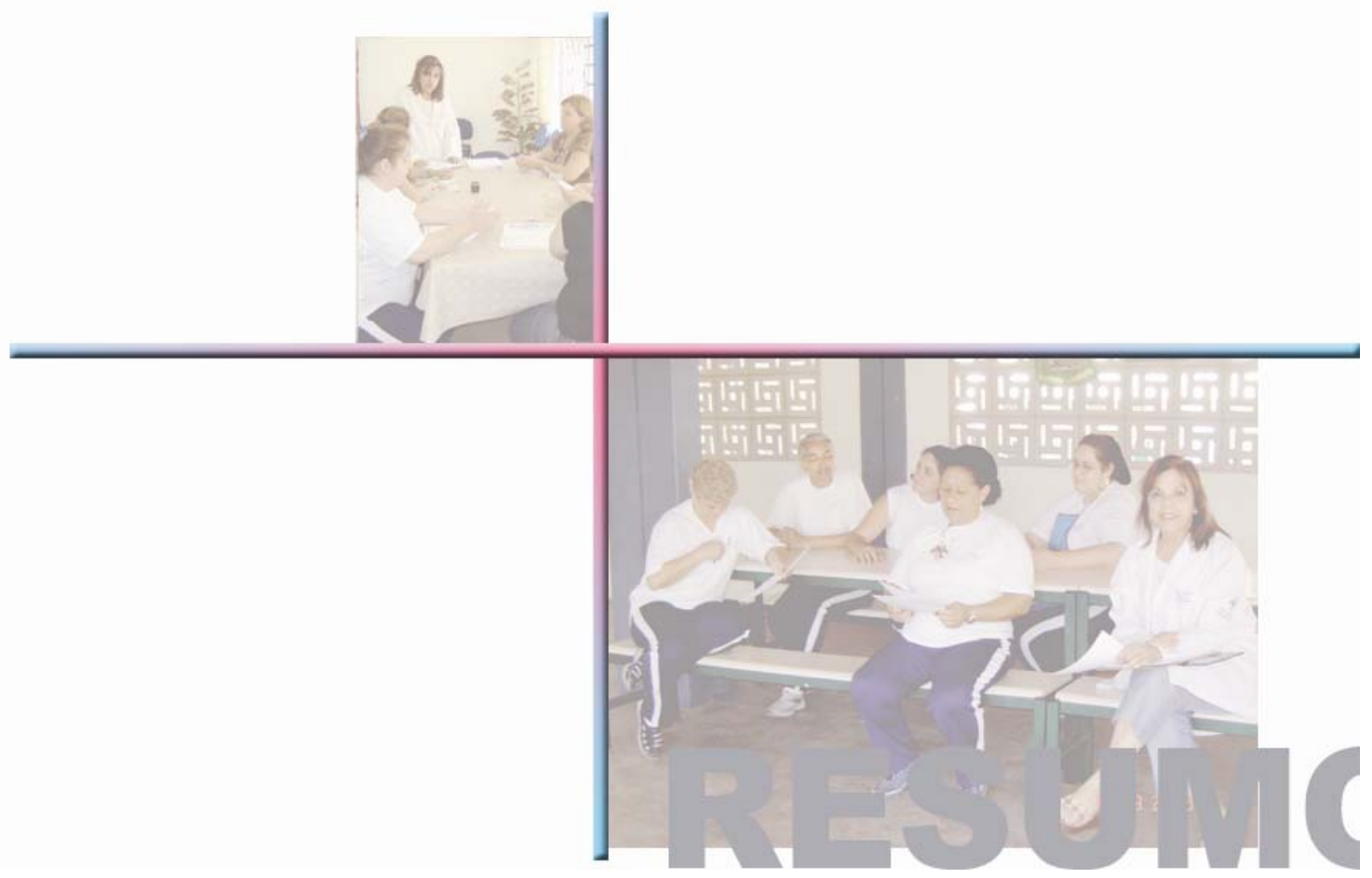

RESUMO 


\section{RESUMO}

Os professores da rede pública são referenciais de informações sobre saúde bucal para seus alunos, seja por trazer a responsabilidade dos ensinamentos em saúde, ou por estabelecer, pela convivência periódica, oportunidades de trabalhar questões dos cuidados na prevenção das doenças bucais através de suas atitudes e ensinamentos, na construção dos conceitos de saúde em geral aos escolares. Este trabalho teve como objetivo geral analisar o conhecimento dos professores de ensino fundamental da $1^{\mathrm{a}}$ à $4^{\mathrm{a}}$ série da rede pública no município de Bauru-SP sobre saúde bucal. Como objetivo específico, investigar qual a atitude desses profissionais, em relação à educação em saúde e promoção de saúde bucal na sala de aula. Foram realizadas entrevistas individuais por meio da aplicação de um questionário semi-estruturado contendo 20 questões abertas e fechadas, com 307 professores, de 24 escolas estaduais e municipais. Verificou-se, neste estudo, resultados em que se destacam: $92,5 \%$ dos entrevistados relataram falar da importância da saúde bucal para os alunos, 36,0 \% receberam treinamento de saúde bucal, 48,0 \% citaram prevenção à cárie como função do flúor. Por outro lado, 10,7\% desconheciam local de acesso ao flúor, $38 \%$ responderam não 
conhecer o que é doença periodontal, e $23 \%$ responderam não saber socorrer traumatismo dentário. Concluiu-se que os professores pesquisados demonstraram ter algum conhecimento em saúde bucal, embora em algumas conceituações importantes afirmassem desconhecimento. O reforço de conhecimentos científicos, com práticas educativas e preventivas direcionadas para saúde bucal nas escolas, torna-se relevante visto que muitas vezes são as únicas fontes portadoras dessas informações diárias para os alunos das escolas públicas.

Palavras chaves: Educação em saúde bucal. Educação em saúde. Saúde escolar. Saúde bucal. Conhecimentos, atitudes e prática em saúde. 


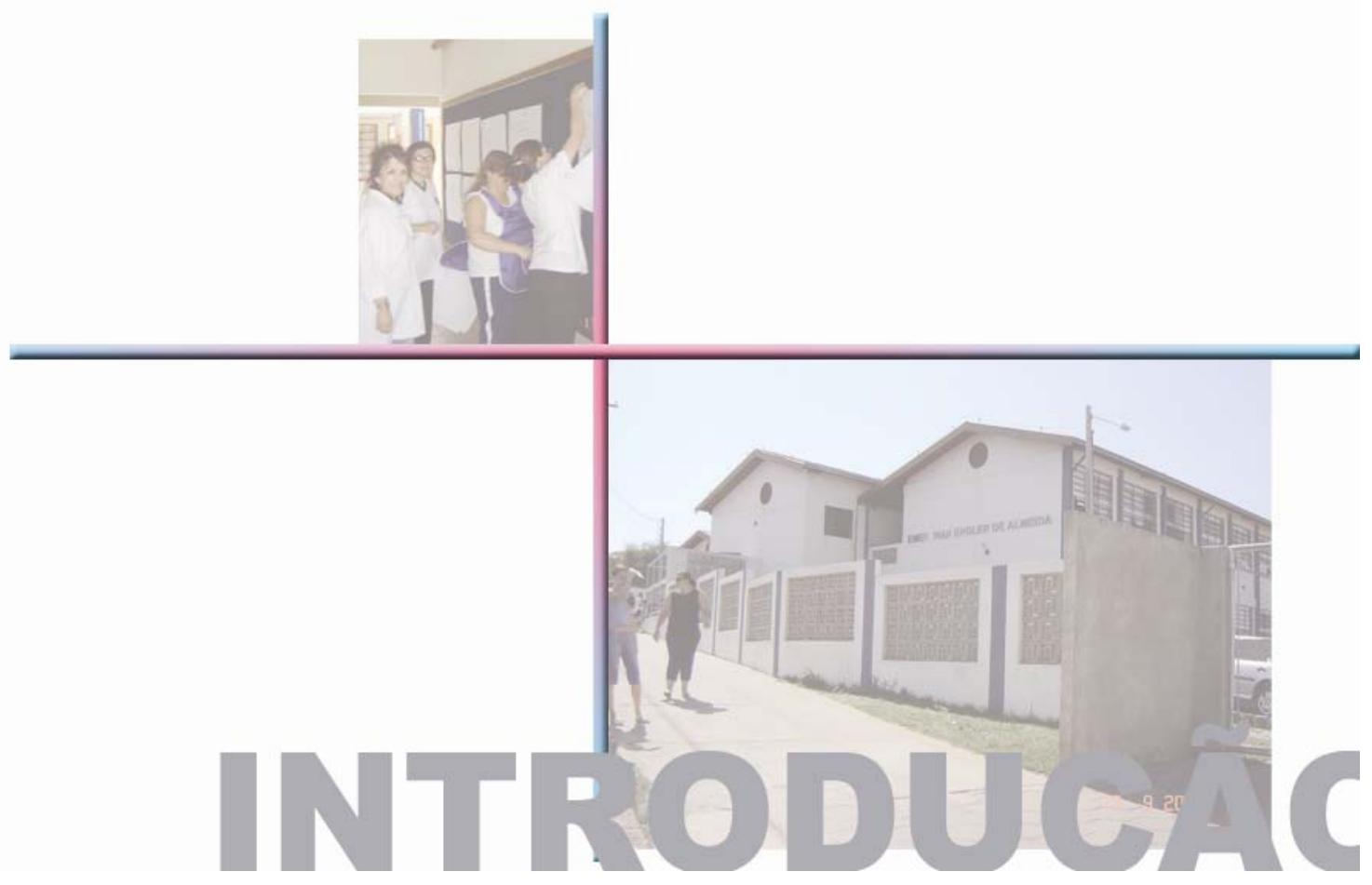

INTRODUÇÃO 


\section{1 - INTRODUÇÃO}

O alicerce para uma vida saudável está na educação tradicional, social, política, educação econômica, ambiental e entre outros tipos de educação em saúde. Para que a população tenha saúde, torna-se necessária e indispensável a aquisição de conhecimentos desde a mais tenra idade. Portanto, prevenção, educação, conhecimento e cultura devem ser incutidos nas comunidades durante a formação do indivíduo.

Desenvolver ações educativas de saúde em escolares pode trazer muitos benefícios para o futuro e para a formação desses estudantes, ensinando-os a terem um comportamento adequado em relação à saúde, valorização da saúde como um bem do indivíduo, ressaltando também sua responsabilidade nesse sentido, através do autocuidado.

A saúde bucal, implícita na saúde integral, está diretamente relacionada com informação, renda, trabalho, moradia, transporte, condições de alimentação, liberdade e acesso a serviços de saúde. Nesse sentido, o caminho para conquistar uma boa saúde bucal está fundamentalmente ligado à luta pela melhoria dos determinantes sociais, políticos, econômicos e educacionais, o que implica em maior preocupação com os menos favorecidos (PAULETO ${ }^{75}, 2004$ ).

Nesse aspecto, o que preocupa ainda é que em muitos municípios do Brasil encontram-se grupos de escolares, principalmente os da rede pública, que apresentam alto índice de cárie e condições precárias de saúde bucal. Essa situação é um desafio para a Odontologia, que necessita encontrar novos caminhos e construir estratégias em 
educação para a saúde com a finalidade de atingir o controle das doenças nessa comunidade. Observa-se que quanto mais desfavorável é a condição econômica, maior o número de dentes afetados e maior a severidade da doença (DRUMOND 29 , 2004). Evidenciam-se, portanto, variações regidas por influências de fatores coadjuvantes capazes de condicionar o aparecimento de doenças na população, como aspectos socioeconômicos, políticos, educacionais e culturais com seus diferenciais e também com as características ambientais (FREIRE ${ }^{37}$, 1999).

Destaca-se que o ambiente escolar é realmente um espaço privilegiado para o desenvolvimento de ações educativas e preventivas, em saúde coletiva, e propício para incentivar os hábitos de higiene bucal (PELLICIONI; TORRES ${ }^{76}$, 1999).

A escola de ensino fundamental torna-se oportuna na apresentação de informações em saúde bucal, pois possui potencial para influenciar o comportamento em saúde das crianças. Outro fator de destaque, na escola, é que o professor, por permanecer por longo tempo com as crianças, pode também influenciá-las nesse estágio da vida em que seus hábitos estão sendo consolidados (Al-TAMINI ${ }^{3}, 1998$ ). Logo, torna-se necessária a presença de profissionais preparados, competentes, dedicados a esse assunto, tanto da área da saúde como da educação, atuando nesse ambiente para acompanhar as crianças nessa fase (FERRIANI ${ }^{32}$, 1990).

Segundo LANG ${ }^{51}$, 1989, quando as informações sobre saúde são dadas pelo próprio professor, a escola tem a vantagem de ter nesse profissional um forte potencial para melhorar a continuidade das instruções do programa em saúde aos escolares, porque ele está sempre presente e também porque torna-se mais barato o custo desse serviço para a escola. Por outro lado, os professores podem não estar atualizados com os conceitos atuais da Odontologia e 
não estar preparados para deterem o conhecimento a fim de ensinar educação em saúde. Por isso torna-se evidente que há necessidade de capacitação, através da educação continuada dos docentes e de toda equipe escolar, nos conceitos atuais de saúde e práticas preventivas.

Acredita-se que através da Educação em Saúde seja possível mudar hábitos e comportamentos dos escolares, porém não basta só educar as crianças se os dirigentes e os responsáveis (pais e professores) carecem de informações adequadas e constantes reforços sobre o assunto. Portanto, é necessário avaliar os futuros educadores na sua formação acadêmica e na sua atuação profissional, para que sejam adequadas as questões pedagógicas curriculares com os conhecimentos científicos e as práticas educativas de prevenção e promoção de saúde bucal, pois esses profissionais levarão todos esses conhecimentos a toda comunidade envolvida com os escolares (FRAGA ${ }^{35}$, 1999). Daí a importância de uma boa formação do educador, não só na sua graduação, mas também propiciando educação continuada para os que já estão na carreira há algum tempo, para que possam identificar não apenas as necessidades de seus alunos, mas também as suas próprias (LEAL $\left.{ }^{52}, 2006\right)$.

Os conhecimentos e as atitudes dos professores de ensino fundamental devem ser avaliados no que diz respeito à etiologia, evolução, e prevenção, da cárie dentária e doença periodontal e também sobre traumatismos dentários (SGANCOHEN ${ }^{95}$, 1999). Para isso é preciso promover nessa população as informações necessárias para manter a saúde, ensinar a desenvolver hábitos saudáveis e conseguir prevenir as doenças bucais, sendo o professor é grande aliado, cooperador e multiplicador das informações dos projetos em saúde desenvolvidos para os escolares (VASCONCELOS ${ }^{110}$, 2001). 
Segundo VASCONCELOS ${ }^{110}$, 2001, a avaliação e a participação dos educadores preparados e comprometidos nesse processo de formação em saúde bucal na escola é muito favorável, e se apresenta como uma esperança e mais um caminho a ser utilizado para que se possa alcançar melhora nos índices de saúde e de higiene bucal na população brasileira.

Por todo conjunto de ações educativas e preventivas que se espera que os professores do ensino fundamental desenvolvam com seus alunos nas escolas, e por serem grandes colaboradores na realização dos projetos de educação em saúde, estes profissionais foram os sujeitos de estudo desta pesquisa. 


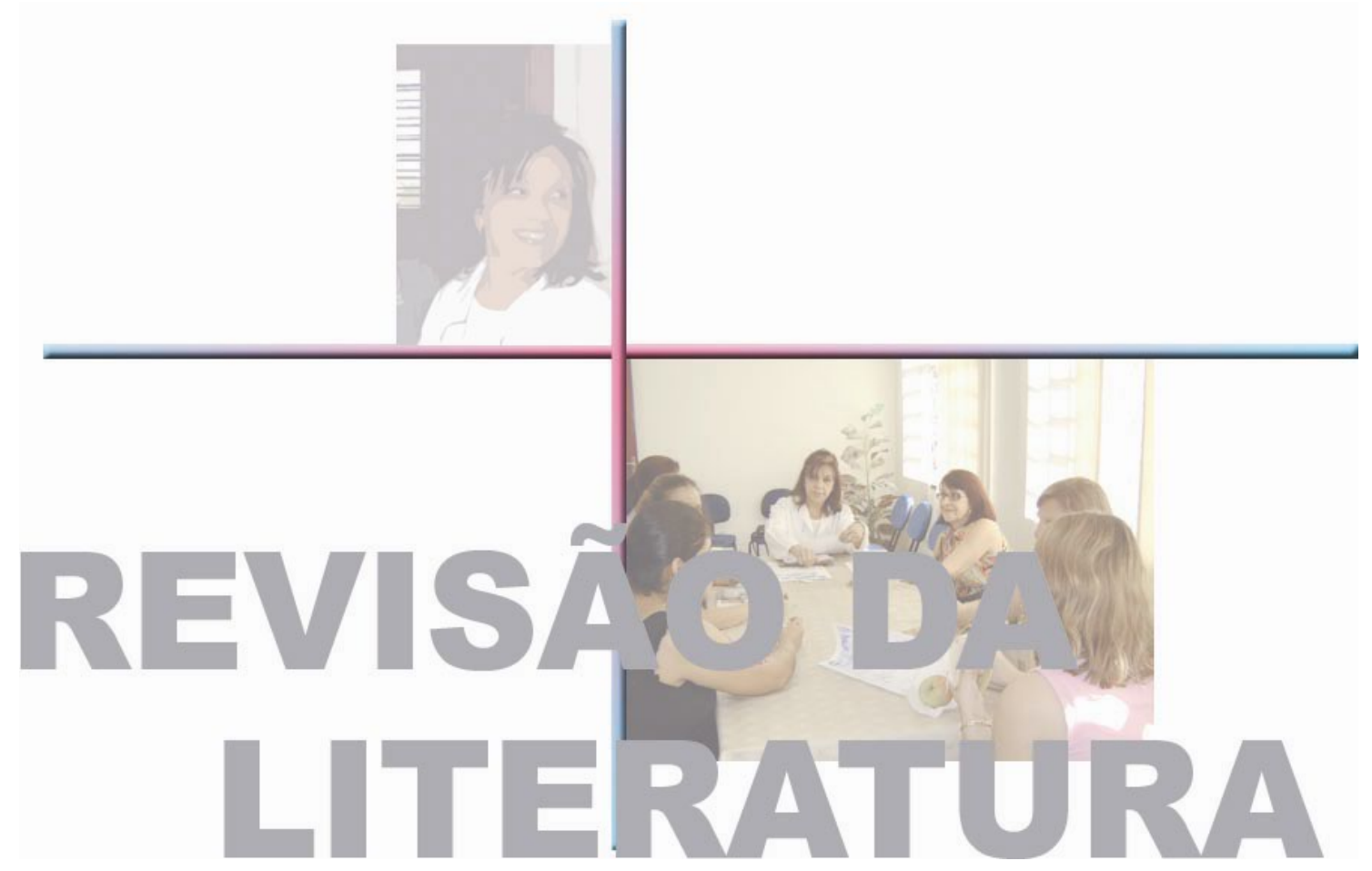

REVISÃO DA LITERATURA 


\section{2 - REVISÃO DA LITERATURA}

\subsection{Educação.}

É inquestionável o papel primordial do professor na qualidade da educação das crianças, jovens e adultos que freqüentam escolas, pois sobre ele reside a responsabilidade de ensinar, e é isso que dele se espera. O Brasil só poderá superar a inaceitável situação de desigualdade na sociedade se romper com a desigualdade de acesso às oportunidades. Portanto, desenvolver a educação de qualidade é fator condicionante para esse acesso. Na área da educação, há muitos estudos nacionais e internacionais que possibilitam o conhecimento sobre o que faz a diferença nesse campo. Referem que para atuar de maneira efetiva na qualidade da educação há que se considerar muito além do conhecimento e do envolvimento do professor. Sabe-se que, no ambiente escolar, alguns pontos como infra-estrutura, recursos educacionais, perfil do diretor, gestão, incidem sobre os resultados e precisam ser pensados, trabalhados $e$ disponibilizados de maneira integrada. A educação é um instrumento fundamental para rompermos a perpetuação das injustiças sociais (LEAL $\left.{ }^{52}, 2006\right)$.

Define-se educação como ação exercida pelas gerações adultas sobre as gerações jovens para adaptá-las à vida social, é um trabalho sistematizado, seletivo, orientador, pelo qual nos ajustamos à vida, de acordo com as necessidades, ideais e propósitos dominantes, é um 
aperfeiçoamento integral de todas as faculdades humanas" (CHAVES $\left.{ }^{22}, 1986\right)$.

Segundo a conceituação de GOOD in CHAVES ${ }^{22}$, 1986, editor do Dictionary of Education, temos duas explicações sobre educação, sendo a primeira um processo através do qual as pessoas são submetidas à influência de um ambiente selecionado e controlado (especialmente na escola), de tal forma que possam atingir competência social e o melhor desenvolvimento possível.

A segunda é o conjunto de todos os processos através dos quais, a pessoa desenvolve capacidades, atitudes e outras formas de comportamento positivo na sociedade onde vive.

A palavra "educar" origina-se do latim educare, que significa conduzir de um estado para outro, é modificar numa certa direção o que é suscetível de educação. O ato pedagógico pode então ser definido como uma atividade sistemática de interação entre seres sociais, tanto em nível intrapessoal como ambiental interação essa que se configura em uma ação exercida sobre o sujeito ou grupos de sujeitos, visando a provocar nelas mudanças tão eficazes que os tornem elementos ativos dessa própria ação exercida (BASTOS, SALES PERES et al. ${ }^{9}$, in PEREIRA ${ }^{78}$, 2003).

No Brasil, a estrutura da educação formal é composta pela educação básica, formada pela educação infantil, ensino fundamental e médio, e educação superior. Segundo HILGERT ${ }^{46}$, 2001, o ensino fundamental ocupa um espaço intermediário na estrutura da educação brasileira. Na LEI DE DIRETRIZES E BASES DA EDUCAÇÃO ${ }^{10}$ (LDB), esse ciclo educativo escolar infantil de ensino tem duração mínima de oito anos, é obrigatório e gratuito na escola pública e tem objetivo de formação básica do cidadão, mediante capítulo I e Il do artigo 21 da Lei no 9394/96. 
I- O desenvolvimento da capacidade de aprender, tendo como meios básicos o pleno domínio da leitura, da escrita e do cálculo.

II- A compreensão do ambiente natural e social do sistema.

Os primeiros ciclos do ensino fundamental são tradicionalmente conhecidos na literatura educacional brasileira como séries iniciais segundo HILGERT ${ }^{46}, 2001$, são compostos no primeiro ciclo pelas quatro primeiras séries, sendo da $1^{\mathrm{a}}$ à $4^{\mathrm{a}}$ série, e nos demais seguimentos do segundo ciclo da $5^{\mathrm{a}}$ à $8^{\mathrm{a}}$ série.

O regime de trabalho no ensino fundamental que envolve o trabalho com séries iniciais, na maioria das escolas públicas, se efetiva pelo regime de unidoscência, ou seja, um professor se responsabiliza pela efetivação do currículo restrito proposto pela escola, o qual compreende a identificação de conteúdos programáticos, a determinação de objetivos educacionais, as seleção de procedimentos e recursos didáticos e pedagógicos e a avaliação geral do processo. De um modo geral, cabe a este professor o papel de educador que, ampliando suas ações, também assume o papel de educador em saúde como um todo e saúde bucal em especial. A necessidade de alcançar novos caminhos para conquistas de melhores índices de saúde bucal dos nossos escolares faz refletir sobre a qualidade do ensino em saúde que as escolas públicas oferecem através dos ensinamentos dos seus docentes (HILGERT ${ }^{46}, 2001$ ).

Desenvolver ações educativas de saúde em escolares pode trazer muitos benefícios para o futuro e formação desses estudantes, conduzindo-os a formarem comportamentos adequados em relação à saúde, valorização da saúde como um bem do indivíduo, ressaltando também suas responsabilidades nesse sentido. 
Para $L E A L^{52}$, 2005, países reconhecidos pela sua competitividade investem pesadamente na educação, para que no futuro seu diferencial competitivo não esteja apoiado em mão-de-obra barata. Promover o desenvolvimento sustentável para o Brasil pressupõe voltar esforços para a melhoria da educação.

A melhoria da educação, segundo o autor citado, eleva a produtividade da economia e amplia, conseqüentemente a competitividade externa de um país, fator fundamental no atual contexto de globalização.

A educação é uma prática que está sujeita à organização de uma dada sociedade e deve criar um espaço de intervenção nessa realidade, com objetivo de mudá-la, transformá-la. Em uma comunidade estudantil organizada, as ações educativas de saúde podem influenciar de uma forma saudável a realidade de cada escolar, melhorando o modo de vida, as crenças, os hábitos, e ajudá-los nas suas necessidades de saúde e conceituar uma boa qualidade de vida. Essas ações devem ter como premissa a educação como um processo de diálogo, indagação, reflexão, questionamento e ação partilhada.

Essa forma de educação propõe tornar as pessoas cada vez mais capazes de pensar, aprender a ter consciência crítica, e de encontrar as alternativas de resolver seus problemas, dentre eles o de saúde-doença, e não apenas de seguir normas recomendadas de como ter mais saúde ou evitar doenças.

Educadores em saúde e educação têm o compromisso de compartilhar seu conhecimento técnico específico, reconhecendo que os escolares e as suas comunidades trazem suas experiências e um saber que deve ser levado em conta. Antes de propor mudanças na maneira de pensar e agir do outro, o educador deve repensar sobre 
suas próprias práticas, pois só assim provocará mudanças no outro (AÇÕES EDUCATIVAS NO SUS ${ }^{61}$, 1997).

Os profissionais da educação e da saúde têm dever ético de apresentar a adoção de um novo comportamento voltado para prevenção. A educação em saúde bucal, segundo SHEIHAN ${ }^{96}, 2001$, necessita de mudanças. A compreensão e adoção dos princípios da saúde bucal pública direcionados à prevenção, devem ser considerados tão essenciais quanto o conhecimento dos princípios clínicos básicos. O uso de medidas preventivas no sentido de melhorar a saúde bucal das comunidades tem alcançado resultados eficientes, quando a motivação dos indivíduos é usada como método educativo. Essa ação educativa deve ser contínua e efetiva, devendo ser evitada a interrupção desses métodos, principalmente quando o ensino é projetado para crianças e adolescentes de comunidade estudantil (GARCIA ${ }^{40}, 1998$ ).

Um grande desafio da Odontologia atual é atuar junto à população infantil, provendo-a de informações necessárias ao desenvolvimento de hábitos para manter a saúde e prevenir as doenças bucais, numa mudança de atitude em relação a essas doenças que freqüentemente são tidas como inevitáveis pela população. A participação dos educadores no processo de formação de bons hábitos em saúde bucal é favorável, sendo mais um meio a ser utilizado para se alcançar melhores índices de saúde e higiene na população brasileira (VASCONCELOS $\left.{ }^{110}, 2001\right)$.

A importância dos padrões de autocuidado para a prevenção de doenças da boca foram estudados por TOMITA ${ }^{102}$, 2001, citando a relevância de programas e investimentos que busquem melhorias à atenção à saúde bucal para os jovens e adolescentes, sendo estes considerável parcela da população brasileira. Quando métodos educacionais são aplicados na forma de motivação, devem possibilitar aos escolares uma educação e 
entendimento sobre a saúde da boca, e se traduzir em mudanças efetivas quanto ao autocuidado, e provocar conseqüentes resultados satisfatórios sobre os níveis de saúde bucal.

Para promover impacto nas ações educativas em saúde, GARCIA ${ }^{40}$, 1998, cita que há necessidade de profissionais das áreas da saúde e da psicopedagogia para melhorar a compreensão do uso da educação como instrumento de mudanças. Para que isso ocorra, o trabalho de motivação e educação de escolares deve pautar-se também pelo entusiasmo, pois o que se faz com crença, entusiasmo e prazer tem o poder de contagiar indivíduos (PETRY; PRETTO ${ }^{80}, 1997$ ).

A educação e motivação quando bem direcionados aos escolares, são capazes de despertar interesse pela manutenção da saúde, podendo despertar os alunos para o desenvolvimento de uma consciência crítica das reais causas de seus problemas de saúde. Os professores de ensino fundamental, quando preparados, agem também na veiculação de informações sobre saúde bucal para crianças. Esses profissionais muito podem colaborar com a educação em saúde na sala de aula, e esse constante convívio com escolares favorece o desenvolvimento de orientação quanto aos cuidados com a saúde bucal agindo, assim, como parceiros dos programas preventivo-educativos (FERREIRA ${ }^{31}$, 2005).

\section{2. Educação e saúde.}

A saúde tem uma relação muito forte com o processo educativo. A maneira como vivemos, a nossa saúde, nossa personalidade, estão relacionadas entre si e, ao mesmo 
tempo, intimamente vinculadas a nossa educação (MARTINEZ $\left.{ }^{63}, 1996\right)$.

HILGERT ${ }^{46}$, 2001, diz que a saúde freqüentemente tem sido inserida como um dos objetivos gerais da educação, por isso os ensinamentos de saúde são enfatizados desde o nível primário de ensino, fundamentando-se na realidade vivenciada.

O saber educar em saúde, segundo VOLSCHAN ${ }^{112}$, 2002, necessita de conhecimentos das práticas preventivas em saúde. Tal conhecimento não é inerente à maioria das pessoas e tampouco é evidenciado nas formações de profissionais que estão envolvidos com a criança na escola. No entanto essa prática de prevenção em saúde deve utilizada por todos da área (professores, nutricionistas, equipe de saúde bucal, inspetores sanitários, pessoal do serviço de saúde). Tanto os profissionais da área de educação bem como da saúde têm sobre seus ombros a responsabilidade desses conhecimentos.

Quando a criança inicia sua vida escolar, traz consigo a valoração dos comportamentos favoráveis e desfavoráveis à saúde, que são oriundos da família e outros grupos de relação mais direta. Durante a infância e a adolescência, épocas decisivas na construção de condutas, a escola passa a assumir um papel destacado devido à sua função social e sua potencialidade para o desenvolvimento de um trabalho sistematizado e contínuo. Por isso deve a escola assumir explicitamente a responsabilidade pela educação em saúde, já que a conformação de atitudes estará fortemente associada a valores que o professor e toda comunidade escolar transmitirão inevitavelmente aos alunos durante o convívio escolar (HILGERT $\left.{ }^{46}, 2001\right)$.

Cita HILGERT ${ }^{46}$, 2001, que os valores que se expressam na escola por meio de aspectos concretos como a qualidade da merenda escolar, a existência de instalações e 
equipamentos para a higiene corporal e bucal, a limpeza das dependências, as atividades propostas, a relação professoraluno, são apreendidos pelas crianças na sua vivência diária. O ensino de saúde tem sido um desafio para educação no que se refere à possibilidade de garantir uma aprendizagem efetiva e transformadora de atitudes e hábitos de vida.

Estudos de SILVEIRA ${ }^{100}$, 2000, mostraram que, na última década, foram implementadas pelo Ministério da Educação mudanças no cenário da educação em saúde, em decorrência da LEI DE DIRETRIZES E BASES ${ }^{10}$, LDB, 1996, originando grande impacto no sistema educacional infantil do país, introduzindo os "temas transversais", uma novidade na época em termos de currículo brasileiro, entre os quais o tema "saúde".

Essas propostas que se sucederam na educação brasileira, segundo SILVEIRA ${ }^{100}$, 2000, foram influenciadas pelas correntes de pensamentos pedagógicos, discutidos sempre com o propósito de provocar mudanças necessárias à melhoria da qualidade de vida e saúde da população. Algumas dessas discussões, vindas das Conferências Internacionais de Saúde, refletiram na necessidade de intensificar os estudos de educação em saúde nas escolas de educação fundamental, tendo como paradigma a saúde dentro e fora da escola.

Tal estratégia, de acordo com o MINISTÉRIO DA EDUCAÇÃO ${ }^{68}$, 1997, objetivava a que esses temas chamados transversais (Ética, Saúde, Meio ambiente, Trabalho e Consumo, Orientação Sexual e Pluralidade Cultural), se caracterizassem por tratar questões relacionadas com 0 exercício da cidadania, sugerindo um estudo integral da saúde. Fazer ensinamentos críticos sobre levar em conta a qualidade da água que se consome e do ar que se respira, as condições de fabricação e uso de equipamentos bélicos, o consumismo desenfreado e a miséria, a degradação social ou a desnutrição, os estilos de vida pessoais e as formas de 
inserção das diferentes parcelas da população no mundo do trabalho. Ainda se considerou, nessa estratégia, a importância de que fossem estudados os processos éticos relacionados ao direito à vida e à saúde, aos direitos e deveres, às ações e omissões de indivíduos e grupos sociais, e ainda dos serviços privados e do poder público (MINISTÉRIO DA EDUCAÇÃO ${ }^{68}$, 1997e).

Ainda nesse contexto, segundo o MINISTÉRIO DA EDUCAÇÃO ${ }^{68}$, 1997, as experiências mostraram que apenas transmitir informações sobre o funcionamento do corpo humano, descrições das características das doenças e também o conjunto de hábitos de higiene, não foram suficientes para que os alunos desenvolvessem atitudes de vida saudável. A criança traz consigo, quando vem para a escola, comportamentos oriundos da família ou de outros grupos que freqüenta. Portanto, a educação para a saúde na escola, durante a infância e adolescência, deve levar em conta os aspectos envolvidos no dia-a-dia, para que o aprendizado seja facilitado e os conceitos adquiridos. Para tanto, devem ser apresentados de maneira crescente em suas relações sociais diárias e com o meio ambiente, tanto no enfrentamento de situações adversas, bem como de opiniões grupais negativas para a saúde ou diante da necessidade de transformar hábitos e reavaliar crenças e tabus, inclusive na dimensão afetiva que necessariamente trazem consigo.

De acordo com o parecer do MINISTÉRIO DA EDUCACAO ${ }^{68}$, 1997, a escola pode assumir um papel destacado de educação em saúde, na construção de condutas e hábitos saudáveis, e os valores que o professor e toda comunidade escolar transmitirão inevitavelmente aos alunos durante o convívio escolar estão associados fortemente a essa conformação de atitudes na relação professor-aluno e são apreendidos pelas crianças na sua vivência diária. 
Com essa preocupação, a Secretaria de Educação Fundamental, do MINISTÉRIO DA EDUCAÇÃO ${ }^{68}$, 1997 , selecionou conteúdos de educação em saúde, para orientar os professores em trabalhos pedagógicos nos primeiro e segundo ciclos do ensino fundamental. Segundo esses critérios, foram selecionados os de relevância com atualidades, e organizados de tal maneira a dar sentido às dimensões conceituais e atitudinais interconectadas, para que pudessem orientar práticas de uma vida saudável. O trabalho educativo necessita promover transformações próprias do crescimento e desenvolvimento humano, capacitando o indivíduo para que se aproprie dos meios para tomar medidas práticas de autocuidado em geral, e especificamente diante de situações de risco $\left(\operatorname{MEC}^{68}, 1997\right)$.

Através dos conteúdos pedagógicos para educação em saúde, oferecidos pelo $\mathrm{MEC}^{68}, 1997$, o professor pode proporcionar a introdução de conhecimentos muito interessantes direcionados para o primeiro ciclo do ensino fundamental, sobre o funcionamento do corpo humano, visando à formação de sujeitos do processo saúde-doença, para que os escolares possam conhecer-se e cuidar-se, valorizando sua identidade e características pessoais. Há destaque para o valorização do aprendizado na identificação das semelhanças e diferenças entre as pessoas, sejam hereditárias ou adquiridas, inclusive em traços de temperamento, permitindo reconhecer a diversidade e a pluralidade, que não se confundem com discriminação preconceituosa ou com a aceitação da desigualdade. Incluise, nesse ponto, o desenvolvimento de postura respeitosa e colaborativa com relação a pessoas portadoras de deficiências.

A importância da higiene corporal é também tratada nos conteúdos propostos pelo $\mathrm{MEC}^{68}$, 1997, como condição para uma vida saudável. Enfatizam que a aquisição de hábitos 
de higiene corporal tem início na infância, destacando-se a importância de sua prática sistemática. As experiências de fazer junto com a criança os procedimentos passíveis de execução no ambiente escolar, como lavagem das mãos ou escovação dos dentes podem, por exemplo, ter significado importante na aprendizagem. O grande desafio na abordagem da higiene corporal é aproveitar a realidade do aluno. O conhecimento dessa realidade é fundamental para recolher e elaborar informações sobre os usos e costumes da comunidade e um caminho para articular conhecimentos, atitudes e possibilidades de ação.

As propostas do MINISTÉRIO DA EDUCAÇÃO ${ }^{68}, 1997$, nos conteúdos pedagógicos de educação em saúde também destacam a recomendação para que a alimentação seja adequada, pois esse é um fator essencial no crescimento e desenvolvimento, no desempenho de atividades cotidianas, na promoção e na recuperação da saúde. Deve ser abordado que a desnutrição e as anemias são ainda importantes problemas de saúde pública no Brasil e fatores primordiais para a baixa capacidade de reação às doenças. Citam as propostas que a alimentação inadequada apresenta-se como principal problema a ser enfrentado e, portanto, a pesquisa de alimentos ricos em nutrientes e a necessidade de se adotar um cardápio equilibrado e compatível com as possibilidades oferecidas pelas particularidades de cada realidade são formas acessíveis ao trabalho da escola no sentido de prevenir a desnutrição e as anemias.

Por outro lado, destaca-se também a preocupação com a obesidade, que é um problema de saúde de grandes proporções, com elevada prevalência entre jovens de diferentes grupos sociais. Nesse contexto o consumo excessivo de açúcar, especialmente entre as crianças, é destacado como um hábito alimentar a ser transformado, não se justificando o grau de consumo (em todo o país) por 
necessidades calóricas e sim por fatores culturais, o que causa prejuízos amplamente comprovados, particularmente à saúde bucal, contribuindo também para a obesidade precoce.

Houve uma preocupação no preparo do aluno para aprender sobre uma alimentação saudável, devendo-se enfatizar a associação entre higiene e alimentação. É importante também apontar sobre a possibilidade de contaminação da água e de alimentos por fezes, ou por produtos químicos e agrotóxicos, assim como identificação de água, alimentos e objetos contaminados como fontes de doença, os quais devem ser reconhecidas e evitadas (MEC ${ }^{68}$, 1997) . Observa-se que esse conteúdo pedagógico proposto, é bastante detalhado com relação aos ensinamentos de medidas práticas de autocuidado, o que propicia boas informações em saúde para que o professor possa utilizá-las na vivência dos escolares.

Nesse aspecto de práticas educativas para escolares, VALADÃO ${ }^{108}$, 2004, citando SILVA ${ }^{98}$, 2002, concluiu que os projetos voltados para a saúde na escola na atualidade são formulados de forma independente dos projetos pedagógicos, e com tendência a realizar-se de modo descontínuo e pouco abrangente em relação às redes de ensino. A multiplicidade de temas, as ações e projetos buscam refletir uma clara intenção de ampliar a visão e a abordagem da saúde em suas relações com o ambiente e a qualidade de vida. Refere VALADÃO ${ }^{108}$, 2004, que temas tradicionais da saúde escolar, como educação sanitária, aparece de relevância menor que os outros ambientais, e são apenas citados como parte do trabalho realizado.

A concepção de saúde que se pretende estudar nas escolas surge embasada no que esses movimentos renovadores enfatizam: a necessidade de se formar cidadãos que busquem acesso aos recursos para viver e criem as oportunidades para ter maior poder de decisão. Esse 
sentimento de cidadania deve ter um caráter múltiplo e histórico de sua determinação: a saúde tendo determinantes sociais, econômicos e ambientais. Esses fatores conjugados podem agregar potencial de transformação de uma situação de saúde, muito mais do que qualquer um deles isoladamente (SILVEIRA $\left.{ }^{100}, 2000\right)$.

Há necessidade de se instaurar movimentos integrais pela formação da cidadania, a fim de que os cidadãos se fortaleçam e se mobilizem para obter melhores condições de vida. Este é um autêntico processo educacional de mudanças, que resulte em níveis crescentes de organização popular, em políticas saudáveis e legislação que se regulamente. Nesse modo de pensar, a escola se destaca como um local onde se recebe um processo gradativo da formação da cidadania, para a conquista definitiva de melhores níveis de saúde e de qualidade de vida. Porém essa é uma tarefa que se restringe além dos bancos escolares, não se pode esperar apenas da esfera da atuação escolar na vida do indivíduo. É preciso mais do que se pode aprender no espaço da escola. Não há como avançar na direção da organização popular sem que se estabeleça sinergismo entre escola e movimentos populares (LEFEVRE ${ }^{53}, 1998$ ).

Esse posicionamento de sinergismo com movimentos populares, explica SILVEIRA ${ }^{100}$, 2000, não desvaloriza os programas educativos existentes, nem os programas já desenvolvidos pelos sistemas de saúde até agora. O desafio é articular esses dois níveis em promoção da saúde, possibilitando abordar questões que ultrapassem os limites individuais, devendo incorporar também visão ecológica da saúde. A saúde da infância e da adolescência tem um valor fundamental e deve ser promovida em todas as sociedades e países. A promoção da saúde ensinada nas escolas deve ser abrangente, com um envolvimento que englobe a colaboração dos jovens, das famílias, escolas, serviços de saúde, 
organizações não governamentais e, principalmente, do Estado. Para que essa ação geral aconteça é indispensável este enfoque integral à Educação para Saúde, seja fora ou dentro da escola. O estudo da saúde no ambiente escolar deve estar de acordo com as representações sociais que os diversos protagonistas que atuam na escola têm a respeito do que seja saúde, educação e, principalmente, das interseções a serem estabelecidas entre saúde e educação e entre a família, a comunidade e a escola.

A educação e a saúde possuem campos comuns de conhecimentos que poderão fazer com que a sociedade possa compreender melhor as relações entre as condições de vida e trabalho, de saúde e de doença. Os profissionais de educação e da saúde devem-se colocar a serviço da sociedade como um todo, construindo o exercício da cidadania, e os deveres e direitos do cidadão, para que ele possa lutar por melhores condições de vida e saúde. O conhecimento técnico científico de ambas as áreas (saúde e educação) se integram, interrelacionam e se articulam, com o propósito de promover transformações na vida dos indivíduos e conseqüentemente modificarem a realidade de uma sociedade se esses conhecimentos forem absorvidos (COSTA e FUSCELLA ${ }^{23}$, 1999). Educar para a Saúde é uma maneira de provocar nas pessoas, mudanças nos hábitos prejudiciais à saúde, por isso necessita do envolvimento da comunidade.

Nesse pensamento, destacamos o papel que a escola, que é uma das instituições básicas da sociedade, tem na realização do processo de educação em saúde dos alunos.

Estudos de BOURGET ${ }^{16}, 2005$, citam que o conceito e a maneira como entendemos a saúde varia segundo a época em que vivemos numa dada sociedade e a maneira como a mesma está organizada.

Refere o mesmo autor que, a partir da segunda guerra mundial, surgiu a Organização Mundial de Saúde 
(OMS) criada pela Organização das Nações Unidas (ONU), composta por vários técnicos de diversos países, com objetivos de estudar e sugerir para as nações alternativas para melhorar a saúde mundial. Posteriormente, nas várias conferências de saúde que aconteceram, estudando melhorias para saúde, novos pareceres de saúde foram definidos, no qual os países passaram a reconhecer a saúde como um direito fundamental de todo cidadão. Mas o que se percebe é que só alguns detêm essa oportunidade.

A saúde no seu sentido mais abrangente é a resultante das condições de alimentação, habitação, educação, renda, meio ambiente, trabalho, lazer, liberdade, acesso e posse da terra e acesso a serviços de saúde (BOURGET ${ }^{16}$, 2005). Faz-se necessário desenvolver nos estudantes em idade escolar e na comunidade consciência crítica a respeito das causas dos problemas e, ao mesmo tempo, ensinar a criar condições para atuar no sentido de mudanças. A promoção de saúde na escola implica na participação dos profissionais da educação e da saúde e também da população como transformadores destas realidades (BOURGET ${ }^{16}, 2005$ ).

O processo educativo em saúde é responsabilidade primeira da família. Porém, como a família muitas vezes não dispõe de informações nem condições básicas, cabe à Saúde Escolar, através dos profissionais de saúde e de educação, assessorá-la nesse compromisso junto à criança em idade escolar.

Nesse aspecto, a rede básica de saúde pode priorizar a atuação junto às crianças vinculadas à instituição escolar, pois todos os ambientes escolares têm acesso facilitado para ações da equipe de saúde. As crianças que se encontram fora da escola também necessitam de atenção e devem ser envolvidas, de alguma maneira, nos Programas de Saúde Escolar. 
Os autores que seguem desenvolveram trabalhos sobre educação em saúde nas escolas.

MACEDO; LACAZ NETTO ${ }^{58}$, 1986, produziram um manual de higienizacão bucal para servir como motivação dos pacientes nos programas de educação em saúde bucal. Muito útil para motivar a população e ensinamento nas escolas, portanto, útil para o professor também. É constituído de textos explicativos e ilustrações sobre a causa das doenças bucais e como progridem e também como proceder para evitar a instalação das doenças e alcançar a prevenção.

FREIRE et al. ${ }^{37}$, 1999, estudaram escolares da rede pública, de 6 a 12 anos. Pesquisaram a prevalência de cárie e a necessidade de tratamento. Concluíram que a alta prevalência de cárie em escolares do interior de Goiás sugere a necessidade de se implantarem medidas educativas e preventivas em saúde bucal que intervenham nos reais determinantes da doença na população.

O processo educativo no contexto Educação em Saúde foi estudado por FLORES ${ }^{33}$, 1999, que emitiu reflexões sobre práticas profissionais em saúde dos setores médico, odontológico, enfermagem, fonoaudiologia, nutrição, sala de visitas, visitas domiciliares, etc. As práticas de atenção à saúde são um caminho que estará sempre por ser construído e de responsabilidade de todos os membros das equipes de trabalho das redes de serviços.

UNFER E SALIBA ${ }^{107}$, 2000, realizaram um estudo sobre o conhecimento popular e as práticas cotidianas em saúde bucal. Foram entrevistadas 389 pessoas com idades entre 15 a 79 anos, usuários de serviços públicos municipais de Santa Maria, RS. Utilizaram entrevista semi-estruturada e organizados em conjuntos de categorias descritivas, permitindo sua distribuição em tabela de freqüência. Concluíram que os programas de saúde devem considerar os aspectos relativos ao conhecimento e as práticas em saúde 
bucal, para viabilizar o processo de capacitação da população e promover a responsabilização coletiva da promoção da saúde em todos os níveis da população.

HAWKINS et al. ${ }^{4}, 2000$, estudaram a efetividade de 2 métodos de educação em saúde em crianças avaliadas para melhorar o conhecimento em higiene bucal entre crianças de alto risco de cárie. Foram examinadas 50 escolas de ensino fundamental do Canadá, e separados em dois grupos de escolas para receber treinamentos. Um grupo recebeu reforço por duas sessões de pequenos grupos, e o outro recebeu apenas uma única sessão básica. Concluíram que entre os dois métodos, o de duas sessões de pequenos grupos foi mais efetivo para crianças de alto risco de cárie.

MALTZ; SILVA ${ }^{60}$, 2001, estudaram escolares brasileiros, de 12 anos de idade, de redes particulares e públicas, para determinar a relação entre cárie, gengivite, e fluorose e nível sócio econômico. Observaram que os alunos da rede escolar pública apresentavam uma maior prevalência de doença cárie, sangramento gengival e uma menor freqüência de fluorose dentária.

Quanto à prevenção das doenças bucais, existe uma grande importância trabalhar na educação em saúde bucal nas escolas, sobre o uso correto das escovas dentais, tanto conhecer sobre a durabilidade útil, quanto saber sobre a maciez e também, freqüências de escovações. Esses aspectos foram estudados pelos autores PANZERI et al. ${ }^{74}$, 1993, PINTO ${ }^{82}$, 1997; TUMENAS ${ }^{105}$; 1999, BARROS et al. ${ }^{12}$, 2001, em seus respectivos trabalhos. Realizaram avaliações onde destacaram as características das escovas dentais, uma revisão no histórico da trajetória e cuidados com a higiene bucal, e também orientações para a população sobre as quantidades de escovações, qual a melhor escova e os cuidados na transmissão de microorganismos pela escova dental. 
Estudaram o tema educação em saúde na escola, visto por graduandos em pedagogia, abordando o assunto no currículo acadêmico, LEONELLO; L' ABBATE54, 2006. O objetivo foi pesquisar qual a compreensão desses alunos, futuros educadores e orientadores, na identificação da abordagem Educação em Saúde na Graduação em Pedagogia de uma Universidade Paulista. Os alunos na pesquisa responderam não ter especificamente abordagem Educação em Saúde, em seus currículos acadêmicos, somente matérias próximas a questões de saúde. Também 72,5\% consideraram que o currículo acadêmico não possibilitava abordagem ao tema saúde na escola, e $27,5 \%$ consideravam que o curso abordava parcialmente. Concluíram que havia necessidade urgente de uma maior articulação entre os responsáveis pelos setores da educação, da saúde e comunidade, no sentido de refletir e debater temáticas de Educação e da Saúde, e a relação entre os dois campos. Desse modo fazer surgir ações coletivas e planejadas de saúde e educação para que fossem mais condizentes com a realidade social, e promovessem uma fixação melhor do tema entre os estudantes.

\subsection{Saúde na escola.}

A saúde nas cidades brasileiras, assim como no município de Bauru, tem apresentado uma série de problemas, sendo motivo de destaque pela mídia diariamente nesses últimos anos. Esses acontecimentos vêm gerando descontentamento tanto das pessoas que utilizam os serviços públicos de saúde, como também dos seus gestores e dos profissionais da área. 
Mesmo havendo no Brasil propostas atualizadas de ensinamentos sobre temas de saúde nos Parâmetros Curriculares Nacionais, direcionadas aos professores para suas praticas diárias, eles não evidenciam essas ações de saúde de maneira eficaz, deixando aquém das expectativas as propostas do ensino do programa de saúde do escolar (GUIMARÃES $\left.{ }^{43}, 2005\right)$.

$\mathrm{Na}$ realidade, o que se encontra no contexto de educação em saúde na escola é bem diferente de uma situação ideal, determinada por lei. O estudo dessa legislação revelou que a tentativa de Educação em Saúde foi inferida há décadas por leis criadas no passado, implantando esse estudo no ensino primário, sem contudo se realizar. É preciso destacar que há falhas na formação desses profissionais e na estrutura e funcionamento do sistema escolar (BÓGUS ${ }^{15}$, 1990)

Por outro lado, os projetos de educação em saúde que são levados para os escolares apresentam dificuldades na sua continuidade, apesar das tentativas do seu desenvolvimento. Quando por necessidade política há uma contenção de despesas, muitos projetos desenvolvidos em escolas perdem sua atuação.

Nas escolas, os problemas de se desenvolver uma educação integral a todas as crianças é uma luta constante. Observa-se a dificuldade de acesso e permanência nas escolas das crianças pertencentes a famílias de classe menos favorecida, demonstrando assim que o texto legal da constituição em assegurar Educação e Saúde da população não tem viabilizado conquistas adequadas em saúde e educação, e tampouco a qualidade de vida para muitos (CARVALHO²1, 1995).

$\mathrm{Na}$ prática, a escola continua sendo palco de disputa entre os diversos programas, porém de forma desarticulada, e 
muitas vezes com superposições das ações e com diretrizes e intencionalidade díspares.

A saúde escolar brasileira acompanhou de perto as tendências internacionais. No início, foi marcada por movimentos higienistas do princípio do século. Era denominado "higiene escolar", e esses movimentos propunham medidas de asseio e higiene dos escolares com o propósito de evitar que doenças contagiosas invadissem a escola. Utilizavam medidas inspecionistas voltadas para as camadas populares entendidas como marginalizadas e atrasadas.

Depois na década de 70, a saúde entrou na escola com designação de programas de saúde, com objetivos de levar para as crianças e adolescentes hábitos saudáveis de higiene pessoal, alimentação, prática desportiva ao trabalho e ao lazer (MINISTÉRIO DA EDUCAÇÃO ${ }^{66}, 1998$ ).

Nas décadas seguintes, 80 e 90, acontecimentos influenciaram uma revisão ampla da concepção de educação em saúde na escola. Um conjunto de mudanças no cenário epidemiológico e político-institucional no Brasil e no mundo impulsionou projetos educativos nas escolas, relacionados à saúde e sexualidade, devido a doenças emergentes como a Síndrome de Imunodeficiência Adquirida e Doenças Sexualmente Transmissíveis (AIDS/DST). Esses projetos educativos em saúde passaram a dar informações aos escolares dos riscos associados à morbidade para a prevenção da mortalidade. Os modelos antigos de atenção à saúde (médico e odontológico) sediados na escola, nesse período, sofreram rupturas importantes, e por decorrência de vários fatores ocorreu a falência de tais modelos de educação em saúde. Surgiram então os princípios do Sistema único de Saúde (SUS) que implicavam em rever a atenção à saúde da criança em idade escolar, que era marginalizada no atendimento realizado pelo setor de saúde da época. A literatura da época citava que este modelo proposto pelo SUS 
poderia ser um marco na história do desenvolvimento da saúde na escola brasileira, considerando-se que, se fossem aplicados os princípios de articulação intersetorial, universalização, participação e descentralização (CYRINO ${ }^{26}$, 1999).

De fato houve uma implantação progressiva na gestão dos sistemas de saúde e educação. Os projetos de integração docente-assistencial estabeleceram vínculos entre universidades e serviços. Foram gerados inúmeros projetos no campo da saúde na escola, e trouxeram algumas capacitações de professores e projetos de temas específicos. Com a elaboração da LEI DE DIRETRIZES E BASES ${ }^{10}$, LDB em 1996, surgiram vários conjuntos de documentos curriculares de caráter orientador para as escolas e sistemas estaduais e municipais de educação. Em 2002, segundo VALADÃO ${ }^{108}$, 2004, um levantamento junto aos Secretários Estaduais de Educação de todo o Brasil mostrou que muitos projetos vinham sendo implantados em todos os sistemas estaduais de ensino, incluindo temas sociais no currículo escolar, sem serem formalizados com a concepção de Escola Promotora de Saúde. Esse mesmo autor, observou que tais projetos ainda se realizam de forma descontínua e pouco abrangentes, em relação às redes de ensino, não sendo eficientes para gerar efeitos de mudanças comportamentais.

No Ministério da Educação, o programa Saúde do escolar continua existindo. Esse programa pode ser acessado pela internet, no site oficial do governo: http://www.mec.gov.br. Ele se encarrega basicamente da realização periódica de procedimentos de detecção de problemas de visão. Já no Ministério da Saúde, desde a definição do SUS, a saúde na escola não chegou a constituirse em política, com programa ou área claramente definida. Muitos projetos e diversos programas disputam esse palco, 
porém se mostram descontínuos, e desarticulados, portanto não efetivos. (VALADÃO ${ }^{108}, 2004$ )

Em nível nacional, mesmo com acontecimentos de debates acadêmicos e com participações da sociedade civil, e ao lado de inúmeras experiências tanto nas instituições de educação bem como da prestação dos serviços de saúde, ainda não foi possível levar à conformação de novas políticas estratégicas para inserção da questão saúde nos sistemas de ensino. A saúde na escola brasileira contempla hoje, segundo VALADÃO ${ }^{108}$, 2004, uma mescla de antigas e novas idéias e práticas. O cenário do estudo, portanto, é um cenário no qual os princípios, leis, conceitos e práticas têm relação direta com a promoção da saúde. Mas, no âmbito da escola se perpassam, conflitam, superpõem, raramente se comunicam ou se articulam. A saúde escolar se mostra tal qual uma metáfora de PILON ${ }^{81}$, 1995, onde a saúde na escola é um cenário no qual muitos fios vão sendo trançados sem que se forme um novo tecido, em que os fios se entrelacem numa nova configuração. (VALADÃO $\left.{ }^{108}, 2004\right)$.

Segundo estudos de FOCESI ${ }^{34}, 1992$, a saúde na escola é parte da saúde em geral, envolve a criança em idade escolar, dentro e fora da escola em razão do que passa a ser responsabilidade de todos, tanto dos órgãos governamentais quanto dos comunitários. A sua importância está na colaboração efetiva para a formação do homem e do cidadão.

A escola, afirma DIAS ${ }^{28}, 2004$, é uma importante instituição de educação dos indivíduos e colabora na formação de cidadãos ativos e críticos, promovendo melhoria na qualidade de vida da sociedade. O ambiente escolar favorece o aprendizado, permite o reforço dos conteúdos a longo tempo e a utilização de diferentes estratégias. A educação em saúde na escola deve ser ensinada sem visar à manipulação das crianças, desvinculada dos conhecimentos 
de saúde, mas ensinar de forma que ajude a cada aluno compreender a si próprio como um ser físico, mental, e social.

Para FOCESI ${ }^{34}$, 1992, a saúde na escola está ligada a um compromisso de vida melhor e mais saudável para todos. Para que haja saúde na escola é muito importante que existam fatores imprescindíveis como: a vontade política, a infra-estrutura social e a educação em saúde, objetivando a melhor qualidade de vida para o escolar.

A promoção de saúde na escola, cita a autora, é um processo que vai possibilitar a cada população avaliar a qualidade de vida que lhe é oferecida, atuar sobre ela para conseguir cada vez mais saúde. A Educação em Saúde com vistas à Promoção deve colaborar na capacitação do futuro cidadão para ser um agente de transformação, para que ele participe de movimentos que lutem pela preservação do ambiente e melhoria das condições de vida.

A Prevenção de Doenças necessita da Educação, segundo FOCESI ${ }^{34}$, 1992, para preparar o escolar para conhecer o próprio corpo e seu funcionamento, conhecer a etiologia das doenças, sua relação com o meio e medidas para evitá-las. Deve- se analisar com o educando o processo do crescimento e desenvolvimento, de acordo com a sua idade, devendo ele aprender as modificações que ocorrem em seu corpo e sua personalidade, aprender sobre a adolescência e suas dificuldades, ter a compreensão de sua sexualidade e a formação da mentalidade prevencionista em relação às doenças sexualmente transmissíveis, à gestação precoce, aos acidentes, enfim a tudo que possa impedi-lo de ter uma vida feliz na escola ou na comunidade.

No controle da Saúde, a educação deve possibilitar ao escolar o conhecimento e a utilização dos recursos de saúde a que tem direito, refere FOCESI ${ }^{34}, 1992$, portanto é necessário despertar-lhe a responsabilidade de seguir as recomendações médicas, alertá-lo para o perigo da auto- 
medicação, mostrar-lhe os caminhos da medicina alternativa, dar-lhe subsídios para que possa colaborar no seu próprio tratamento como sujeito do processo. Ainda FOCESI ${ }^{34}, 1992$, citou que, para trabalhar com os escolares, os profissionais da saúde e educação precisam ser avaliados e reciclados em seus conhecimentos e técnicas. A própria escola e suas redondezas devem servir como exemplo de ambiente físico e emocionais saudáveis para que possa haver a promoção de saúde.

GUIMARÃES ${ }^{43}$, 2005, refere que o professor é um elemento fundamental nesse contexto, e que ele e um multiplicador de idéias, por isso deve estar capacitado ao abordar esses conceitos de saúde, e a escola tem essa atribuição de promoção de saúde, formando crianças nesse processo de construção do conhecimento.

De acordo com FOCESI ${ }^{34}, 1992$, a saúde na escola só será implantada com propriedade se todos nós, profissionais de Educação e Saúde, refletirmos profundamente nossa responsabilidade em formarmos o escolar como ser humano e cidadão, e nos dermos as mãos para efetivação desse objetivo, único caminho para prepará-lo como sujeito da transformação da vida atual, em outra cada vez mais saudável e feliz.

Os professores, segundo BÓGUS ${ }^{15}$, 1990, precisam estar bem formados, informados e orientados sobre esse tema, para reconhecer a importância da sua atuação na área da saúde na escola. Para isso, é preciso que sejam modificados os currículos e sejam oferecidas oportunidades de treinamentos, atualização e aperfeiçoamento sobre as mais variadas questões relativas à saúde e suas implicações no cotidiano dos alunos e familiares.

Um estudo sobre a problemática da saúde da criança, no Brasil, foi publicado por LOUREIRO ${ }^{56}$, 1996. O autor citado, fez reflexões onde demonstrou, segundo ele, o quadro 
caótico relativo às condições da população no Brasil. Referiu a educação como instrumento estratégico para superar as dificuldades e o papel do educador no processo aprendizagem. Concluiu que a educação é o caminho para superação da realidade de vida da população e, em particular, da criança brasileira.

Outro estudo a respeito de reflexões críticas de programações educativas para escolares foi realizado por PAULETO et al. ${ }^{75}$, 2004, o qual se baseou em revisão bibliográfica sobre os programas de saúde bucal desenvolvidos em âmbito nacional, em especial no estado de São Paulo durante os anos de 1991 a 2001. Concluíram que é preciso substituir modelos ancorados em práticas de comunicação unidirecional, dogmática e autoritária com foco na transmissão de informação, pela discussão e reflexão, desencadeadas pela problematizarão de temas de saúde bucal.

Estudos de AQUILANTE et al. ${ }^{6}$, 2003, avaliaram um Programa de Educação em Saúde Bucal, pautado na verificação da performance de higiene do paciente através do índice PHP. Uma entrevista também foi realizada, baseada em um questionário elaborado pesquisando os conhecimentos em saúde bucal de crianças de 6 anos de uma pré-escola, em Bauru, no ano de 2001. Concluíram que os programas educativos promovem conhecimento em saúde bucal e redução do índice da placa nas crianças avaliadas.

Sabe-se que a informação e educação são fundamentais para uma vida saudável. Nesses termos, CORREIA et al. ${ }^{25}$, 2005, produziram uma literatura "Saúde Bucal do bebê ao adolescente: um guia prático". Muitos assuntos são ensinados nesse livro, inclusive procedimentos corretos quando acontece um trauma, resultando em avulsão dental. Citam que é através da boca que adentram uma parcela significativa de germes e patógenos. A participação 
dos pais, em casa, e dos professores ensinando saúde na escola, favorece o aprendizado de uma higiene bucal eficiente.

\section{4. O professor e o sistema educacional.}

O ambiente escolar faz parte das boas lembranças da infância, para aqueles que puderam freqüentar a escola durante algum período de sua vida, refere CARLOTTO ${ }^{17}$, 2003. Sejam elas recordações daqueles momentos alegres do recreio, ou pelas brincadeiras e corre-corre com os colegas, até mesmo nas recordações das primeiras letras que pareciam tão difíceis naquela época, ou na descoberta do universo das palavras e números foram elementos importantes que ficaram retidos na memória.

A autora referida acima citou que dentre as várias lembranças do período das primeiras letras não há dúvidas de que a relação afetiva com a primeira professora ou professor é um dos fatos mais marcantes da vida infantil. Talvez seja esta, possivelmente, uma das figuras externas ao ambiente familiar a que mais carinho se dedica e se enternece ao evocar da sua memória.

Os tempos mudaram, o ensino mudou, a escola mudou e, como conseqüência, o professor se viu impulsionado a essas mudanças, tendo que responder a um profundo e exigente desafio pessoal diante das novas expectativas projetadas sobre ele.

Observa ainda CARLOTTO ${ }^{17}, 2003$, que, à medida que a escola perdeu seu caráter elitista, houve a expansão da escolarização e a escola pública não conseguiu dar conta desse processo, pois também não recebeu investimentos nem apoio político-educacional nesse sentido. E para o desencanto das escolas públicas, o ensino privado passou a desempenhar importante papel no cenário educacional. 
A formação dos professores do ensino fundamental no Brasil, segundo CAMPOS ${ }^{18}$, 1999, sofreu influências das reformas da nova legislação educacional que são introduzidas nos sistemas educacionais estaduais e municipais. Observou o autor que existem no ensino escolar infantil "ordens hierárquicas" na formação dos professores. Uma ordem hierárquica que é constituída por: professora ou professor de $1^{\text {a }}$ à $4^{\text {a }}$ série, formados no curso Normal secundário e, em anos mais recentes, no curso de Pedagogia, com a mesma formação, a professora e o professor de pré-escola, sendo que muitas vezes a trajetória deles se inicia na pré-escola, ou em substituição a outros professores, para depois "progredir" nas primeiras séries do Ensino Fundamental, o antigo primário. São professoras generalistas, a maioria mulheres, que participam às vezes de sindicatos com orientação mais moderada e assistencialista.

Continuando, o autor relata também que existem os professores especialistas, pertencentes a uma segunda ordem, formados em curso superior, que lecionam disciplina específica a partir da $5^{\mathrm{a}}$ série, antiga $1^{\mathrm{a}}$ série do ginásio, com uma formação prévia que privilegia o conteúdo, participando geralmente de sindicatos mais combativos e politizados. Seu papel tradicional foi definido no curso secundário público de elite, de cunho acadêmico, que garantia o acesso ao curso superior. Hoje se nota que tenham perdido essa possibilidade, e buscam resgatá-las nas representações e nos debates sobre as reformas educacionais.

Ainda há uma terceira ordem hierárquica referida por CAMPOS $^{19}$, 1999, e que merece ser considerada com respeito, a dos educadores leigos, que são mal pagos e, muitas vezes, sem vínculo formal de emprego. Estão presentes na maioria das creches, tanto públicas como conveniadas, nas escolas rurais unidocentes das regiões mais pobres, nas escolas comunitárias das favelas de cidades do 
Nordeste e do Norte, nos programas pré-escolares de baixocusto, ou como monitores de educação de adultos. Essas educadoras, na sua maioria mulheres, grande parte delas negras, muitas vezes estão vinculadas a programas educacionais fora da área de educação, ligados a órgãos de assistência social, a entidades filantrópicas ou comunitárias. Atendem os filhos da pobreza, aquelas crianças e adolescentes que costumam ser rejeitados pelos sistemas formais de ensino.

Esse conjunto "ordens hierárquicas" segundo CAMPOS $^{19}$, 1999, persiste e sobreviveu a sucessivas reformas legais e organizacionais que sucederam e em nada sofreram de modificações na constituição de suas carreiras. Em muitas situações observou-se que até houve incentivo no recrutamento de professoras leigas, mostrando assim que são necessárias, mesmo sendo consideradas educadoras leigas. Com o aumento de professores primários formados em cursos de Pedagogia, notou-se que não ocorreu alteração do perfil desses professores. Até incorporaram a transformação da queda social da carreira, absorvendo a perda de prestígio, origem social diversa, condições de trabalho mais difíceis, porém sem perder seus lugares na estratificação interna da profissão. Todas essas professoras na atualidade são responsáveis de igual modo por levar informações de temas transversais aos seus alunos no ensino fundamental.

O papel do professor de escola primária foi observado em relatos dos próprios professores de ensino fundamental, que manifestaram suas opiniões quanto às características de ser um bom professor: a responsabilidade, dedicação e envolvimento no trabalho, afetividade permeando a prática, a paciência, compreensão e motivação e estimulação no contexto escolar. Estes aspectos foram registrados no trabalho de OLIVEIRA E ALVES ${ }^{72}, 2005$. 
Conforme esses relatos, as aulas na escola primária precisam ser estrategicamente dadas de forma que haja estímulo do professor voltado a provocar interesse da criança. Ele deve promover esse envolvimento, aguçando a curiosidade dos alunos com temas e materiais que sejam atraentes e chamem atenção, mas deve sempre respeitar a individualidade de cada um, porque ele conhece o aluno de forma mais próxima. O despertar da criança pode se dar vindo da valorização que o professor dá aos outros trabalhos que são realizados na escola. Tais medidas são entendidas como formas de estimular as crianças e favorecer suas atitudes de interesse pela aula.

Ainda citam os autores que o professor que trabalha com crianças deve vir dar aula com vontade, fazer aulas interessantes, bem preparadas, deve incentivar os alunos a participar, precisa valorizar tudo que tem na escola, estimular a participação dos mais desinteressados, destacando o trabalho de um e de outro aluno na sala de aula. É preciso desenvolver uma boa relação entre o professor e o aluno. Se o aluno não gostar do professor, e vice-versa, vai ser difícil o aprendizado porque o professor vai viver muito tempo da vida do aluno junto com ele, às vezes mais tempo até do que o pai ou a mãe da criança. Por isso é preciso não só criar um bom relacionamento como também desenvolver o afeto. O profissional deve procurar, sim, ser um bom professor, saber passar o conteúdo da aula preparada, explicar bem a matéria, mas, se os alunos não gostarem dele, se não existir afeto, eles não irão aprender e não vão se interessar pela aula (OLIVEIRA; ALVES ${ }^{72}, 2005$ ).

Em 2004, SANTOS; ULIANI ${ }^{94}$, 2004, referiram sobre a tarefa de que ser professor hoje em dia é muito difícil, porém prazerosa. Mesmo sendo pouco valorizada, há necessidade de se dedicar, e muito, às pesquisas, ao seu desenvolvimento profissional e aos seus alunos. Esse 
profissional do saber age como um mediador da aprendizagem, participa ativamente do processo de aprender, incentivando a novos saberes, sendo detentor de senso crítico, conhecendo profundamente o campo do saber quando vai ensinar, além de ser capaz de produzir novos conhecimentos através da realidade que o cerca. E isso ainda não é tudo, pois existem mais inúmeras virtudes necessárias a desenvolver para ser professor tais como: paciência, criatividade, humildade, carisma, domínio próprio e de público.

Para ANTUNES ${ }^{5}, 2004$, o professor de verdade deve ser visto como a única fonte do saber, ele sabe provocar curiosidade, ensina a pesquisar e usar o que se aprende em situações novas, transformando o aprender em compreender. Portanto a profissão de docente é uma das mais difíceis, pois existem desafios todos os dias, deve ensinar o aluno a pensar, a pesquisar, etc. Até mesmo o professor nessa vivência aprende todos os dias, é uma forma de educação continuada, e isso deve ser uma constante na vida dele e de todos os profissionais. O problema é a velocidade como o mundo anda, pois sendo cada vez mais rápido, é preciso acompanhar.

GADOTTI ${ }^{39}$, 2000, expressou conceitos importantes sobre o professor, afirmando que esse profissional precisa aprender a conhecer, ter prazer em compreender, descobrir, construir e reconstruir o conhecimento, ter curiosidade, autonomia, atenção. Inútil conhecer tudo. Isso supõe uma cultura geral, o que não prejudica o domínio de certos assuntos especializados. Aprender a conhecer é mais do que aprender a aprender. Aprender mais linguagens e metodologias do que conteúdos, pois estes envelhecem rapidamente. Não basta aprender a conhecer. É preciso aprender a pensar, a pensar a realidade e não apenas "pensar pensamentos", pensar o que já foi dito, o já feito, reproduzir o 
pensamento. É preciso pensar também o novo, reinventar o pensar, pensar e reinventar o futuro.

Ainda GADOTTI ${ }^{39}, 2000$, refere que ser professor hoje é viver intensamente o seu tempo, é conviver, é ter consciência e sensibilidade. O futuro da humanidade não pode ser imaginado sem a presença dos educadores, assim como não se pode pensar num futuro sem poetas e sem filósofos. Os educadores, numa visão emancipadora, não só transformam a informação em conhecimento e em consciência crítica, mas também formam pessoas e as novas gerações. Diante dos falsos pregadores da palavra, dos "marketeiros", eles são os verdadeiros "amantes da sabedoria", os filósofos de que nos falava Sócrates. Eles fazem fluir o saber (não o dado, a informação e o puro conhecimento), porque constroem sentido para a vida das pessoas e para a humanidade e buscam, juntos, um mundo mais justo, mais produtivo, mais saudável para todos. Por tudo isso eles são imprescindíveis (GADOTTI $\left.{ }^{39}, 2000\right)$.

Os professores são a chave para qualquer reforma educacional. Mesmo assim a escassez de professores é imensa, e as situações estão cada vez mais problemáticas, alcançando níveis alarmantes, tanto no hemisfério Norte como no Sul. Mesmo diante desse quadro, os professores detêm o papel essencial para o desenvolvimento cultural, econômico e social das populações, o qual confere a eles uma enorme responsabilidade: promover uma educação de qualidade, além de sua importância em ajudar a população a se preparar para a vida profissional. (UNESCO $\left.{ }^{106}, 2006\right)$.

O professor é um profissional que tem um compromisso político e uma função de ensinar de tudo um pouco, e tem como uma de suas tarefas a responsabilidade de promover a educação em saúde das novas gerações, conforme refere CARVALHO ${ }^{21}$, 1995. Complementa o autor sobre o professor que, muitas vezes, esse profissional não é nem 
lembrado pelos milhões de alfabetizados que aprenderam com ele, e de ingressantes em universidades e por todos os demais profissionais que devem uma parcela de sua vitória a esse educador. Esse profissional em certas ocasiões é questionado em sua competência técnica e compromissos, por não atender a certos interesses dominantes, e então fica obscurecido e relegado, e nem sequer é considerado um profissional assalariado.

Cita o mesmo autor que os aspectos de formação do professor na escola pública trazem a figura do Estado como mantenedor desse profissional, de prepará-lo para o desempenho do seu trabalho específico, e posteriormente, enquanto empregador desse profissional, promover seu aperfeiçoamento e atualização. Refere CARVALHO ${ }^{21}, 1995$, que nas últimas décadas depara-se com um quadro em que se observa que a educação dos educadores tem sido uma tarefa descuidada, não só pela política educacional do Estado bem como pelos seus críticos. Acrescenta-se isso ao fato de que a formação profissional do professor está sendo deficiente e, tecnicamente, desprovida de compromisso político. Vários estudos têm chamado atenção para o fato de a formação profissional ser incompleta e permeada de ideologia das classes dominantes, que se reflete em sua representação no geral, e em específico nos estudos referentes à saúde, o que estaria prejudicando o exercício de sua função educativa em saúde, no sentido de formação do cidadão.

Para esse autor é importante haver integração de ações nos novos paradigmas de estudos de saúde para a comunidade, para que haja a melhoria da condição de vida da população. Quando se deseja uma completa formação do cidadão, e para que educação em saúde não seja só responsabilidade única e exclusiva do professor no ambiente escolar, percebe-se que é preciso formar equipes responsáveis por esta integração, e para que haja cobrança. 
Para isso, é importante que sejam formadas equipes constituídas por representantes da Escola, representantes da Unidade de Saúde (ou Programa de Saúde da Família, PSF) e representantes da Comunidade. E desse modo serem capazes de colaborarem no desenvolvimento e formação do pensamento crítico dos escolares e sua comunidade em relação à qualidade de vida que é oferecida ao cidadão, e na medida em que saúde e educação sejam consideradas entre os pressupostos do Sistema de Saúde, percebam seus direitos inerentes, para não se tornarem simplesmente mercadorias, como objetos a serem consumidos por um consumidor. Com essa visão, na escola existem membros dessa equipe de integração com essa competência e, portanto o professor é um dos mais importantes elementos para a conquista da saúde do estudante. É ele que está mais tempo em contato com a criança e terá condições de apresentar à equipe o resultado de suas observações, e ensiná-la a partir de suas experiências vividas no dia-a-dia.

O professor é também quem, através do processo educativo formal elou informal, estará colaborando na formação de hábitos e atitudes e capacitando os alunos para lidar com as próprias condições de vida e saúde bem como as de sua comunidade. Assim, a escola deixa de ser o lugar de dar somente assistência à saúde, para ser um espaço social que viabiliza ações coletivas de promoção de saúde, tendo como objetivo principal a possibilidade de interferir e colaborar no processo de realização do indivíduo, enquanto cidadão (RAMOS $\left.{ }^{86}, 1990\right)$.

Para CARVALHO ${ }^{21}, 1995$, torna-se necessário, sim, o professor ser participante dos Programas de Saúde que forem propostos no âmbito da Educação em Saúde Escolar. Todos os participantes da rede escolar devem estar comprometidos, e portanto, essa atenção em termos promocionais deveria ser direcionada a todos os professores, alunos e demais 
funcionários que atuam na rede escolar. No entanto, o que se tem observado, cita o autor, é que Programas de Saúde, na realidade quando ensinam Saúde, envolvem apenas os docentes de Ciências e Biologia. Muitos professores, ainda pensam que estes seriam os únicos responsáveis pela saúde escolar ou pelo ensino de saúde na escola, quando na verdade todos os professores são responsáveis. Quando concepções de educação em saúde são ensinadas na escola, deve haver o envolvimento da mesma com questões sociais. Só assim poderia ser considerada válida uma concepção de educação em saúde, desde que se voltasse para a formação do cidadão. Esta é uma visão holística e dinâmica que se preocupa em que o escolar seja orientado para compreender a sua comunidade, relacionando fatos, problemas diários, saúde, recursos existentes e sendo capacitado para, através de uma análise crítica, saber reivindicar ou propor soluções para sanar ou minimizar os problemas existentes. Só os professores comprometidos com esse mesmo embasamento filosófico e que vivenciem a mesma condição de cidadão é que poderão desenvolver uma prática adequada conducente a esses objetivos.

Apesar de todos os problemas, carências e desacertos da educação brasileira, é somente pela aprendizagem formal, obtida na escola, que a maioria das crianças tem acesso a algum tipo de conteúdo cientifico. MELO; FREIRE; BASTOS ${ }^{65}, 2005$, referem que é fundamental que os educadores tenham acesso aos conteúdos científicos. Porém os professores têm dificuldades em internalizar esses conceitos, possivelmente pelo fato de muitos desses conceitos serem discutidos apenas de forma teórica e não prática. Os autores realizaram uma pesquisa com duas professoras de ensino fundamental, analisando um processo de capacitação durante um ano, e discutiram a construção de conceitos em saúde bucal nesse processo. Apesar de que, 
nesta situação, as professoras articulavam a idéia partindo do aluno para chegar até ao conceito cientifico, observaram em várias ocasiões que certos conceitos não eram compreendidos completamente pelas professoras. Em apresentações de peças teatrais com os alunos, as professoras só representavam como motivo de consultas odontológicas as extrações dentárias, dando apenas a idéia mutiladora do elemento dentário, e não referindo outros procedimentos preventivos. Perceberam, no estudo, que as professoras ainda permaneciam com uma visão do dentista como reparador de efeitos, e não como alguém que possa intervir nas causas, promovendo saúde. Concluíram que, durante a capacitação, as professoras se detiveram mais na abordagem dos conceitos da cárie dentária, e prevenção através da alimentação, escovação e do uso do fio dental. Nesse aprendizado falhas relativas a esses conteúdos foram apresentadas durante o trabalho com os alunos na sala de aula, indicando a necessidade de transformar o processo capacitação numa forma continuada.

Estudos de VALADÃO ${ }^{108}$, 2004, mostram que essa dificuldade da educação em saúde nas escolas faz lembrar que os profissionais da saúde que prestam atendimento em Unidades Básicas de Saúde, próximas de escolas públicas, têm também responsabilidades frente às crianças dessa comunidade. A unidade de saúde, através de seus profissionais, para concretizar a proposta do SUS, assim como na escola, têm necessidade de conhecer a população que atende, saber quais são as suas características, os anseios, como vive, trabalha, adoece, morre, etc, a fim de melhor poder atendê-la. As instituições públicas de saúde devem ir ao encontro de sua população próxima, e não apenas cruzar os braços e aguardar passivamente a sua demanda. Este é um grande desafio. No caso da saúde, não apenas atender os que diariamente brigam por uma consulta, mas 
conhecendo sua população, formular programas de atendimento mais amplos que abranjam o processo saúde/doença como resultante das condições de vida e trabalho revelados pela comunidade, fazendo com que esses programas sejam dirigidos para o desenvolvimento de promoção de saúde e até atendimento de necessidades, o que significa um respeito aos direitos do cidadão.

Professores de ensino do primeiro grau, de acordo com VALADÃO ${ }^{108}$, 2004, exercem grande influência sobre o comportamento dos alunos, pois como sabemos o contato diário com seus alunos é longo. Eles podem despertar sua atenção para criar a vontade de aprender, desenvolver condições internas favoráveis à aprendizagem, estimulando o seu desejo de conquistar resultados almejados. Se conseguirem, farão com que o aprendizado se torne um prazer, e eles até dediquem o melhor do seu tempo e de seu esforço nesta tarefa. Escolas de educação infantil e de ensino fundamental possuem qualidades inerentes, como serem fontes de apresentação de informações diárias sobre saúde bucal para seus alunos, realizadas por seus professores. As crianças, nesse tempo escolar, podem ser alcançadas, pois seus hábitos de saúde estão também se formando nessa época.

As expectativas hoje em dia em relação aos professores são surpreendentes. Existem muitas propostas para treinar professores para resolverem problemas de saúde a partir dessa delegação de tarefas. O professor termina quase sempre sendo alvo de críticas quando gera demanda para o sistema de saúde. A participação dos profissionais de saúde na escola, realizando palestras e capacitando os professores em promoção de saúde, e realizando levantamento epidemiológico para se conhecer as necessidades, e podendo fazer planejamentos de atenção, seria um novo caminho no campo da atenção à saúde na 
escola dessa população em idade escolar (VALADÃO ${ }^{108}$, 2004).

Com referência à idade escolar, o conhecimento sobre desenvolvimento saudável da criança na infância média e na puberdade falta ser validado ainda. A odontohebiatria (o cuidar da saúde bucal do adolescente) surge para suprir essa lacuna com relação a esses jovens. Essa faixa de idade muitas vezes não é alcançada por projetos em saúde ou saúde bucal na escola. É um horizonte desejável e necessário nas práticas futuras de saúde, com vistas a construir novas modalidades de atenção ao escolar quando ele não está tendo prioridades no seu atendimento básico. Os professores até a $8^{a}$ série do ensino fundamental, por terem a convivência íntima com seus alunos, devem participar também dessas práticas de educação em saúde adequadas para escolares adolescentes, com princípios fundamentados em pedagogia participativa, e através de suas competências, criatividades, solidariedades, possam redefinir esse papel de educador em saúde direcionado a esses jovens. MEDEIROS ${ }^{64}$, 2004, refere a importância do desenvolvimento de uma relação horizontal facilitando as manifestações espontâneas, aproveitando as experiências das problematizações dos jovens educandos, considerando seus saberes, atitudes, condutas e percepções, com valorização da aprendizagem adquirida, não memorizadas mas mudando comportamento e o estilo de vida para melhor.

Um trabalho de SANT'ANNA et al. ${ }^{91}, 2005$, apresentou que em levantamentos epidemiológicos em adolescentes de 15 anos, em 2004, revelaram um reaparecimento do aumento dos índices de cáries dentárias nos jovens pesquisados, e destacaram a necessidade de intensificar práticas educativas direcionadas especificamente para esses jovens escolares, residentes em de Bauru-SP. O que concretizou os conceitos de que a cárie ainda preocupa 
nessa idade, mesmo com as informações de redução da doença, conforme relatou a Agenda de Notícias ${ }^{2}$, da USP, em 2002 .

Muitos projetos desenvolvidos aos escolares não chegam a atingir esses jovens, porque sofrem descontinuidade antes. Os professores precisam também receber capacitação e educação continuada direcionada para os adolescentes, de preferência, vinda dos profissionais das unidades básicas de saúde próximas da escola, ou das equipes de PSF da região que são bem treinados nesses ensinamentos de práticas de saúde, e assim trabalharem juntos, interagindo em prol da construção da cidadania desses jovens.

Um conhecimento importante também, para o professor, é saber como socorrer traumatismos dentais quando acontecem nas escolas. Esse assunto foi pesquisado por autores citados a seguir, onde referiram que a incidência desses acidentes em escolas estão aumentando. A equipe escolar e professores devem estar bem informados e atualizados, sobre a prevenção e saber como dominar atitudes emergenciais caso ocorra na escola.

TROPE ${ }^{104}$, 2002, estudou sobre os cuidados a serem tomados quando são necessários atendimento de emergências em caso de avulsão dentária. Referiu no seu trabalho sobre o manejo clínico do dente avulsionado, e discutiu estratégias para o tratamento emergencial e os aspectos das estratégias atuais e futuras para tratar esses dentes que sofreram acidentes.

Outro estudo de PACHECO et al. ${ }^{73}$, 2003, sobre esse assunto, pesquisou um grupo de professores do ensino fundamental do Rio de Janeiro, de 5 escolas diferentes. Foi questionado o conhecimento em casos de avulsão dentária, e os tipos de procedimentos que eles realizariam se acontecesse com eles. Observaram que os acidentes mais 
comuns eram avulsão do incisivo superior em crianças de 7 a 11 anos, referiram que isso acontece devido a raiz do dente se apresentar nessa idade ainda incompleta, e com falta de resiliência do ligamento periodontal. Resultando em deslocamento do dente num forte impacto horizontal. Concluíram que há necessidade de mais comunicação entre os profissionais da saúde (acadêmicos e cirurgiões-dentistas) e os professores, no sentido de informar os últimos conhecimentos, para que eles melhorem seus procedimentos nesses casos.

Traumas dentários foram pesquisados por TRAEBERT et al. ${ }^{103}, 2003$. Estudaram a respeito das prevalências de injúrias em dentes permanentes, e os fatores associados entre os escolares de 12 anos em Florianópolis, Santa Catarina. Observaram que a maioria dos acidentes (60\%) ocorria em casa, $18,6 \%$ na escola, e 18,6\% na rua, durante brincadeira ou na prática de esportes. Concluíram que devido à alta prevalência de injúrias na dentição permanente por traumas, essa ocorrência pode ser considerada problema de saúde pública.

Esse assunto foi referido também no livro de CORREIA et al. ${ }^{25}$, 2005, intitulado: "Saúde Bucal do Bebê ao Adolescente: um guia de orientações". Em capítulo especial, referem que traumatismo e acidentes na infância, quando ocorrem, favorecem injúrias dentais do tipo trincas de esmalte, fraturas e avulsão dentária. Apresentam explanações do procedimento aconselham sobre reimplante, observando os cuidados para manusear e transportar o dente até ser reimplantado. O professor precisa estar atualizado nesses conhecimentos, para poder agir corretamente, caso ocorra na escola.

Com respeito ao desgaste que os professores apresentam na sua saúde, DELCOR et al. ${ }^{27}$ em 2004 , estudaram um grupo 250 professores de dez escolas em 
Vitória da Conquista, no estado da Bahía, avaliando as condições de trabalho e saúde. Aplicaram um questionário auto-aplicado, divididos em 5 blocos de questões, sendo: $01^{0}$ bloco investigou informações sobre características demográficas, econômicas, ocupacionais e atividades domésticas. O $2^{\circ}$ bloco de questões avaliou esforços físicos no trabalho como docente, $03^{\circ}$ bloco investigou a saúde do professor, o $4^{\circ}$ bloco investigou a saúde mental, e o $5^{\circ}$ bloco investigou como utilizavam a saúde e segurança do trabalho. Como conclusão dos resultados apresentaram relação entre a prevalência de distúrbio psíquico menores com algumas características do trabalho docente, evidenciando desgaste psicológico do educador.

Um estudo sobre o perfil do professor de educação básica e superior foi referido em artigo da ASSOCIAÇÃO BRASILEIRA DE EDITORES DE LIVROS ${ }^{8}, 2006$. Nesse artigo, as informações foram baseadas em dados estatísticos do Instituto Nacional de Estudos e Pesquisas Educacionais Anísio Teixeira (Inep-MEC). O texto, segundo o artigo, está disponível no endereço do Inep, e apresenta uma radiografia bastante ampla da situação do docente brasileiro. Apresenta um estudo crítico a respeito dos professores com relação a: renda salarial, carga horária, gênero, escolaridade, necessidade de formação continuada e traça comparações pelas regiões do Brasil.

\section{5. Saúde bucal.}

O conteúdo de educação em saúde bucal é de especial importância porque as duas principais doenças bucais, cárie e doença periodontal, podem ser prevenidas através de uma estratégia que enfatize a redução no consumo de comidas ricas em açúcar, o uso adequado de fluoretos e a 
adoção de práticas de higiene bucal como a escovação dental e o uso do fio dental. (HILGERT $\left.{ }^{46}, 2001\right)$.

Para os alunos, a prevenção da cárie dentária, segundo a autora, pode ser abordada de duas maneiras: por uso adequado de fluoretos e por redução de açúcar e do controle da placa bacteriana. Nessas abordagens há necessidade de um preparo científico do professor, pois essas informações devem ser adequadas e corretas, para despertar o interesse dos alunos, utilizando suas experiências e vivências diárias nesses aprendizados.

O uso de fluoretos em saúde pública se dá pela fluoretação das águas de abastecimento num nível de 1 ppm (um miligrama de flúor por litro). Pode ser explicado que tal medida faz com que o flúor seja incorporado aos dentes em desenvolvimento e ficará em contato com as superfícies dos dentes durante toda a vida. Explicar também sobre o uso dos dentifrícios, que são uma prevenção em nível individual. Deve ser enfatizado que o uso de dentifrícios fluoretados na escovação dos dentes após as refeições é recomendado para crianças acima de sete anos, sendo que a quantidade de dentifrício não deve ultrapassar o tamanho de um grão de feijão (HILGERT ${ }^{46}, 2001$ ).

Existe uma tendência atual no sentido de mudar-se de um enfoque individualista para um enfoque de aproximação coletiva no âmbito da saúde pública e deve ser abordado em saúde bucal dessa maneira. Examinam-se os fatores sociais que influenciam e limitam as escolhas das pessoas, ao invés de culpá-las ou responsabilizá-las individualmente por suas escolhas. O que as pessoas fazem (e o que comem) não são questões de simples preferências individuais (CAMPOS ${ }^{18}$, 1999).

Na escola, pode-se promover também prevenção da cárie dentária através de aconselhamentos dietéticos, ou seja, voltada à educação nutricional orientando a quantidade de 
açúcar ingerido nos alimentos. A cárie dental é uma doença multifatorial relacionada a fatores sociais em geral, e nesse sentido é semelhante à maioria das doenças crônicas e a nutrição afeta a experiência de cárie. (LEVINE ${ }^{55}$, 1996).

Para HILGERT ${ }^{46}$, 2001, o controle da placa bacteriana deve ser explicado para os escolares, e devem ser realizados treinamentos através da escovação dos dentes, assim como orienta-los sobre outros métodos eficientes para saúde bucal tais como: comer alimentos fibrosos, maçã e cenoura, que podem auxiliar na limpeza dos dentes e auxilar o massageamento das gengivas. Também o uso de fio dental deve ser instruído para as crianças escolares por profissional da área de saúde capacitado, para aprenderem o uso correto evitando machucar as gengivas. Deve ser enfatizada a correta escovação, para evitar as doenças periodontais, gengivites e periodontites no adulto. O tempo gasto nas escovações deve ser eficiente para remoção da placa bacteriana e, portanto, importante na prevenção de doenças periodontais. Para os escolares,estes devem ser bem ensinados através de escovações supervisionadas.

De acordo com GLASRUD ${ }^{41}$, 1988, os professores de escolas fundamentais muitas vezes demonstram pouquíssimas informações sobre prevenção de doenças bucais e têm cautelas sobre aceitar supervisionar programas preventivos. Nesse estudo, o autor relata que foi feita uma avaliação inspecionando material didático como textos de livros sobre saúde para treinar professores, e não existia nada sobre cuidados dentais e, quando fornecido, era inadequado e inconsistente.

Alguns autores até sugerem que se promova um curso de treinamento geral sobre cuidados de saúde aos professores, caso seja necessário reforçar e atualizar as informações de saúde. Quando não existem programas de 
Saúde Bucal na escola, o professor pode ser o informante aproveitando as épocas favoráveis de comemorações.

A promoção de Saúde nas escolas, segundo PEREIRA et al. ${ }^{78}$, 2003, busca fazer com que as escolhas mais saudáveis tornem-se escolhas mais fáceis e agradáveis, utilizando o instrumento de transformação que é a Educação, não só a formal, mas toda ação que propicie reformulação de hábitos.

Na convivência escolar, o autor acima refere ainda que o professor pode projetar uma influência muito positiva e desenvolver programas de promoção de saúde quando organiza eventos comemorativos nos calendários escolares, como por exemplo "Semana da Nutrição", "Semana da Saúde Bucal", "Pelotão de Higiene" e, em situações de traumatismos na boca dos seus alunos, aproveitar para ensinar a prevenção de acidentes.

O professor é a peça-chave para que se obtenha sucesso nas promoções de saúde em escolares. Deve-se ter uma preocupação cuidadosa quanto às informações de saúde, os hábitos de higiene e saúde geral e bucal dos professores de escolas para que estejam atualizados, e possam ser avaliados de tempos em tempos no sentido de poder proporcionar reciclagens (SILVEIRA ${ }^{99}, 1998$ ).

Os conhecimentos e atitudes dos professores de ensino fundamental devem ser avaliados no que diz respeito à etiologia, evolução e prevenção da cárie dental, doença periodontal e traumatismos dentais. Se necessário, esses conceitos devem ser atualizados para que possam atuar harmoniosamente com a equipe de saúde bucal da escola, e assim contribuir para o sucesso de programas educativos contínuos em saúde que venham a ser aplicados pelo professor nessas escolas (SGAN-COHEN ${ }^{95}, 1999$ ).

Para promover educação em saúde bucal na escola, faz-se necessária a utilização de estratégias e métodos 
adequados de motivação e reforço das informações. Com o propósito de atingir as comunidades escolares em Marajó, MACEDO57, 2006, produziram uma "Cartilha Saúde Bucal do meu aluno", para orientar os professores municipais de Marajó em um projeto de saúde Marajoara, para que gerasse resultados práticos de grande amplitude. O conteúdo da cartilha trata da conscientização da importância da saúde bucal, elaborada de maneira clara e sensível à realidade dos escolares, adaptada ao nível cultural dos alunos, prática, atrativa e comunicativa.

Com o objetivo de preparar os educadores de escolas em geral na difícil missão de transmitir às crianças, aos jovens e aos interessados os conceitos de higiene e prevenção de doenças bucais, os autores, GUIDA e VASCONCELOS 42 , em 1994, elaboraram um livro-texto; "Odontologia na sala de aula e na comunidade, saúde bucal e prevenção". Apresentado de forma simples e objetiva, com inúmeras ilustrações, para facilitar segundo os autores, o seu entendimento e a consulta esclarecendo dúvidas, bem como para elaborar aulas, dele constando também uma parte de elaboração de exercícios e jogos educativos, estimulando desenvolvimento dos conceitos ensinados em saúde bucal.

A continuidade das motivações em educação será responsável pela sedimentação dos conhecimentos de prevenção em saúde. Em adultos, a mudança de hábitos é muito difícil de serem atingidas por influências culturais, sociais e governamentais na maioria das vezes, mas em crianças nessa fase de formação esses objetivos são melhores conquistados (SANTOS; RODRIGUES; GARCIA ${ }^{93}$, 2003).

Para o autor SGAN-COHEN ${ }^{95}, 1999$, os professores de escolas são reconhecidos tradicionalmente e internacionalmente por terem um papel de ser o centro em potencial de educação em saúde bucal, atribuída ao 
conhecimento de saúde bucal que o professor possa ter. Eles têm potencial de preparar futuras gerações informando corretamente sobre os cuidados com a saúde. Os futuros professores devem receber treinamentos sobre promoção de saúde bucal nos seus currículos escolares de formação, ou ainda, possibilitar educação continuada para melhorar a capacitação dos professores no ambiente escolar, desenvolvendo atividades tais como: oficinas de saúde bucal ou" workshops" em saúde bucal ou feiras de saúde bucal.

É importante, cita SGAN-COHEN ${ }^{95}$, 1999, que sejam apresentadas várias palestras de assuntos sobre saúde bucal e atividades afins como: treinamento para os professores e equipes escolares, além dos alunos das escolas e familiares, ministrados por profissionais da saúde especializados e capacitados em educação em saúde ou mesmo por profissionais das Unidades Básicas próximas da escola.

A saúde bucal na escola deve ser trabalhada de uma maneira integradora, segundo trabalhos de PENTEADO e BICUDO PEREIRA ${ }^{77}$, 1996. Para as autoras, nessa integração é importante a presença de diversas populações que convivam com os escolares envolvidos, inclusive tendo as crianças também presentes, para que elas possam ser vistas como um ser total, não fragmentado. É importante que estejam participando: família, profissionais e funcionários da educação e da saúde, dentre outros, estudando suas condições de saúde e desenvolvimento, nos diversos ambientes e condições de vida e a cultura e valores de seu meio social.

Os mesmo autores também se referem à interdisciplinaridade, ou seja, troca de conhecimento específico entre as diversas áreas do serviço público envolvidas com a criança, bem como a possibilidade de organização e execução de projetos e trabalhos, de maneira conjunta e complementar. Os profissionais de saúde e 
educação têm o papel de assessorar a família no compromisso que têm com o processo educativo da criança em idade escolar. Desse modo, complementam ainda os autores PENTEADO e BICUDO PEREIRA ${ }^{77}$, 1996, que na saúde bucal orientada nas escolas deveriam ser envolvidos profissionais da saúde como: o odontólogo, fonoaudiólogo, auxiliar de odontologia, bem como todos os profissionais envolvidos na educação, tais como: pedagogos, professores, pajens de creches, merendeiras, isto é, todos que estejam direta ou indiretamente ligados aos educandos. Dentro das necessidades que as crianças venham a apresentar no futuro, esses profissionais devem ser assessorados por psicólogos, otorrinolaringologistas, pediatras, nutricionistas, dentre outros, o que favorece a interação de especialidades no serviço de saúde, condição essencial para o desenvolvimento de ações contextualizadas numa proposta ampla de saúde e não mais de ações fragmentadas. Seria importante que todos esses profissionais envolvidos com as crianças na escola recebessem essas informações e preparo também em suas formações acadêmicas.

Referem os autores PENTEADO e BICUDO PEREIRA $^{77}$, 1996, que dentre as várias questões a serem abordadas nos programas de saúde bucal nas escolas podemos destacar: a responsabilidade dos pais na formação de hábitos saudáveis na criança; cuidados de higiene bucal; o processo de formação da cárie e de doenças periodontais; a dieta alimentar variada, rica em fibras, não cariogênica e de consistência sólida; a rotina de horários de alimentação; fatores alérgenos causadores de problemas nas vias aéreas superiores; higiene nasal; o prejuízo causado pelos hábitos de sucção de mamadeira, chupeta e dedo, as mal-oclusões e problemas associados; o desenvolvimento de fala e linguagem. Citam que cabe ainda incluir nessas abordagens o direito à amamentação materna, devido aos inúmeros 
benefícios que esta prática exerce no desenvolvimento bucal, facial e afetiva da criança. As figuras mais importantes na estruturação da rotina de vida das crianças são seus pais ou responsáveis, por isso eles devem ser responsáveis em reter esses conhecimentos para a formação de hábitos saudáveis na população infantil, devendo ser alertados e informados sobre todos esses assuntos em programas de saúde bucal.

A vivência da criança em creches e escolas é marcada por uma organização temporal de atividades rotineiras, e a figura do professor representa, muitas vezes, um modelo e um exemplo de hábitos e condutas, daí a importância do papel que o professor desempenha em valorizar e estimular as práticas alimentares e de higiene bucal na rotina escolar.

No ambiente escolar, as reuniões de pais e professores devem conter orientações acessíveis à realidade sócio-cultural de cada população, veiculando informações numa linguagem adequada, simples, nas quais as famílias entendam as explicações e incorporem o processo educativo. Para que isso ocorra é necessária a utilização de recursos de materiais de apoio, como: diapositivos, fotografias, cartazes, filmes, folhetos, jogos, buscando a estimular alguns temas para discussão em grupos, para facilitar esclarecimentos de dúvidas existentes. Essas abordagens educadoras, necessariamente, implicam na participação da população, de forma interativa e continuada, pois só assim o processo se tornará mais dialógico, aumentando a possibilidade de sucesso.

MOIMAZ et al. ${ }^{69}$, 1992, realizaram pesquisa com professores de $1^{\circ} \mathrm{Grau}$, em 3 cidades do interior paulista, na qual concluíram que havia necessidade de conscientização dos professores sobre a importância da manutenção em saúde bucal, e incentivar a ministração do assunto nas aulas. Ter como premissa que a educação para a saúde bucal é uma 
medida muito importante na prevenção dos problemas bucais, pois conscientiza os indivíduos sobre as doenças que podem afetar sua boca, informando as medidas preventivas que existem e os tratamentos indicados para a enfermidade.

A escola tem um papel relevante em relação à educação da personalidade e, como conseqüência, no estilo de vida das pessoas para que tenham saúde.

MORAIS ${ }^{70}, 1999$, referiu que o mais importante nesse tipo de trabalho é fazer com que a informação correta e eficiente sobre saúde e higiene bucal chegue até a criança através de seus próprios professores previamente treinados e fazer com que as crianças e os profissionais se tornem aliados na promoção da saúde, sendo esse o objetivo da nova odontologia integrada a um novo sistema de ensino.

Nas escolas, há necessidade de incorporar os professores nos programas educativo-preventivos em saúde bucal, visando à aquisição de conceitos adequados, para que eles possam transmitir aos alunos informações adequadas, independente das características dos grupos (CAMPOS e GARCIA $\left.^{19}, 2004\right)$.

ABEGG ${ }^{1}, 1999$ publicou sobre Educação em Saúde Bucal em consultórios odontológicos, unidades de saúde e nas escolas, observando que os profissionais, nos consultórios, ainda são treinados da mesma forma para oferecer terapia e cura para seus pacientes, sendo que pouca ênfase é dada à educação em saúde bucal. Nas escolas, apesar de ser oferecida alguma forma de educação em saúde dental na maioria das escolas no mundo, muitos estudos têm demonstrado que a avaliação de sua eficiência não tem sido muito animadora. Nas Unidades Básicas citou que há semelhança com o que ocorre nos consultórios, preocupação com terapias de curas, mais do que práticas coletivas de saúde. 
A rede básica de saúde deve criar meios de atenção à saúde bucal das crianças em idade escolar que não se encontram institucionalizadas, utilizando seus recursos e programas existentes para atingir e orientá-las quanto aos programas específicos. Podem ser utilizadas para o acesso das crianças as campanhas de vacinação em massa, também pelos médicos pediatras orientando seus filhos para programas específicos, ou através de programas educativos comunitários elou com população específica, como crianças de rua, adolescentes, etc, ou da utilização dos meios de comunicação em massa.

As atividades educativas em saúde bucal devem ser realizadas diretamente com a população infantil e adaptadas à faixa de idade e desenvolvimento de cada grupo. Materiais devem ser planejados de maneira a atrair o interesse das crianças, favorecendo sua compreensão e significação. Assim, bonecos, jogos e fantoches podem ser confeccionados, bem como realizados teatros, brincadeiras, atividades manuais, músicas, conjuntamente com as crianças.

A periodicidade e freqüência de tais atividades são elementos importantes para a elaboração das propostas de trabalho, pois um grande espaço de tempo entre uma atividade e outra pode dificultar a efetividade do programa, comprometendo sua qualidade. Os próprios profissionais da equipe de saúde bucal, com a participação dos auxiliares de odontologia, podem planejar, orientar ou executar a confecção dos materiais de apoio para baratear os custos para saúde bucal na escola (PENTEADO e BICUDO PEREIRA ${ }^{77}$, 1996).

O problema da saúde da criança no Brasil foi referido pelo autor LOUREIRO ${ }^{56}$ em 1996. O autor citou que as dificuldades de algumas classes sociais estavam ligadas à qualidade de vida da família, do ambiente e comunidade dessa criança. Referiu também sobre a necessidade de uma ação integrada em Educação e Saúde, estudos sobre 
ambiente de vida, crescimento e desenvolvimento e práticas pedagógicas em saúde fazendo uma reflexão também sobre o que o educador representa na escola, e no processo ensinoaprendizado.

SILVA ${ }^{98}$, 2002, refere ser a escola um espaço com finalidade educativa, e deve ser, sim, aproveitada para o desenvolvimento de ações de educação em saúde para os alunos, suas famílias e para a comunidade em geral, sem se esquecer dos professores e funcionários. Os projetos de saúde na escola devem propor estudos de educação e prevenção em saúde com todos os participantes envolvidos nesse processo, e que tenha metodologia pedagógica para a elaboração de material educativo compatível com o desenvolvimento do autocuidado. É importante a capacitação dos professores e profissionais envolvidos, tanto nos processos educativos como em conteúdos a serem abordados nos grupos, para que os objetivos sejam alcançados com êxito. De acordo com o autor, para possibilitar uma abordagem mais efetiva, essas atividades de educação em saúde na escola devem ser feitas de maneira diferenciada, com técnicas de dinâmica de grupo, e abordagem construtivista, utilizando estratégias e material para motivação, de acordo com a idade da criança.

Um estudo de MAIA e ROCHA ${ }^{59}$, 2002, diz que a escola, nesse contexto de saúde bucal,pode assumir um papel fundamental no processo para construir um novo caminho na prática em saúde, pois ela é, por excelência, o espaço que congrega e atua com uma fatia importantíssima, quando se pensa em potencial educativo: crianças, adolescentes e jovens. Contudo, a grande esperança de transformação para construir novo modelo de práticas em saúde esta calcada na participação popular e nos diversos setores responsáveis pelo bem-estar e pelo desenvolvimento da comunidade. Para isso é preciso conquistar interfaces com setores que entendem a 
saúde como produção social, como construção coletiva, conquistada cotidianamente.

É preciso, de acordo com os autores acima citados, um novo modelo para a saúde atingir a todos e nesse aspecto, surgem as ações do Programa de Saúde da Família (PSF). Cada uma dessa unidade citada deve ser suficientemente equipada para prestar atendimento integral, contínuo e, acima de tudo, resolutivo à população, sendo essa a grande esperança desse novo modelo. Com isso, poderão diminuir as solicitações de exames desnecessários, e também poderá reduzir-se a grande procura direta aos atendimentos de urgências e hospitalares.

Nesse sentido, estabelecer interfaces entre as ações educativas desenvolvidas pela escola com as propostas do Programa de Saúde da Família (PSF) poderá trazer inúmeros benefícios à qualidade de vida das famílias dos alunos. A proximidade entre a escola e o PSF pode ser promovida pela própria comunidade, uma vez que é nela que ambos atuam. Direção e corpo docente, assim como os profissionais da equipe devem buscar formas de comunicação que possam trazer laços (MAIA e ROCHA ${ }^{59}, 2002$ ).

Os autores referidos, a seguir, avaliaram professores e também alunos no sentido de conhecer como estão o conhecimento em saúde bucal, e seus estudos nortearam fundamentos para discussão dos resultados.

Os professores de ensino fundamental da área urbana e rural foram motivo de pesquisa para $L_{A N G}{ }^{11}, 1989$, em Michigan. Analisou através de um questionário, 404 professores, focando quatro tópicos: origens das informações sobre saúde bucal, higiene bucal, prevenção a doenças bucais e o papel dos professores em promoção de saúde. Foi também coletado idade, gênero, experiência no ensino e experiência dental. Como conclusão, referiram que as respostas dos professores sugeriram que os conhecimentos sobre saúde 
bucal estavam imprecisos e incompletos, e o conhecimento dos métodos preventivos variava de acordo com a área geográfica de onde era a escola.

Um grupo de pesquisadores, POMARICO et al. ${ }^{84}$, 1999, estudaram o nível de informação em saúde bucal de professoras e também investigaram o ensino sobre educação em saúde bucal das escolas públicas do $1^{\circ} \mathrm{Grau}$, de $1^{\mathrm{a}}$ a $4^{\text {a }}$ série em 16 das 32 escolas públicas da XX Região Administrativa do Rio de Janeiro. Elaboraram um questionário com 13 perguntas abertas e fechadas, sobre higiene bucal e educação em saúde na escola e aplicaram esse questionário em 51 professoras dessas escolas citadas. Concluíram que o nível de informação das professoras foi inadequado e o ensino em saúde bucal, do ponto de vista qualitativo/quantitativo, foi considerado insuficiente, já que esse conteúdo era sempre apresentado aos alunos através de aulas expositivas e em aulas de reforço. Referem que é importante que, através do ensino público, os profissionais de educação auxiliem no restabelecimento e manutenção da saúde bucal das crianças.

Estudos de FRAGA at el. ${ }^{35} .1999$, analisaram 420 alunos de escolas da rede pública em Bauru. Compararam o comportamento e hábitos de higiene bucal entre os escolares da rede pública, tanto os assistidos quantos os não assistidos pelos projetos de Saúde Coletiva realizados pela Universidade Sagrado Coração USC-Bauru. Concluíram que o papel do programa Educação em Saúde Bucal realizado é eficaz no processo global de prevenção da disciplina estudada.

O conhecimento de saúde bucal de professores foi estudado por MWANGOSI e NYANDINDI ${ }^{71}, 2002$, na Tanzânia. Utilizaram questionário estruturado em 195 futuros professores e 235 professores em serviço, investigando sobre conhecimento em saúde bucal, atitudes relacionadas à saúde bucal, comportamento relacionado a saúde bucal, percepção 
do status da saúde bucal, e fatores associados co comportamento preventivo. Concluíram que os professores em serviço necessitavam ser motivados a melhorar seus conhecimentos com informações sólidas. Dessa maneira facilitaria seus papéis como formadores de educação em saúde bucal nas escolas primárias da Tanzânia.

VELLOZO et al. ${ }^{111}$, 2005, avaliaram a percepção em relação a saúde bucal, de 167 professores e funcionários da $1^{\mathrm{a}}$ à $4^{\mathrm{a}}$ serie, em quatro escolas públicas estaduais e quatro municipais em Campos dos Goytacazes, no Rio de Janeiro. A avaliação foi realizada por meio da aplicação de questionários para investigar percepção em saúde bucal, abordando grau de escolaridade, cargo na escola, tempo de exercício profissional, conhecimentos sobre hábitos de higiene e métodos preventivo-educativos. Os professores acreditavam que palestras e seminários eram as melhores formas de trabalhar educativamente a saúde bucal na escola e consideravam-se motivados com a sua profissão. Houve dificuldade em elaborar conceitos relativos à educação em saúde bucal. Concluíram que existia necessidade de projetos nas escolas, interagindo e integrando professores e funcionários, preparando-os para serem agentes multiplicadores da saúde na escola. 


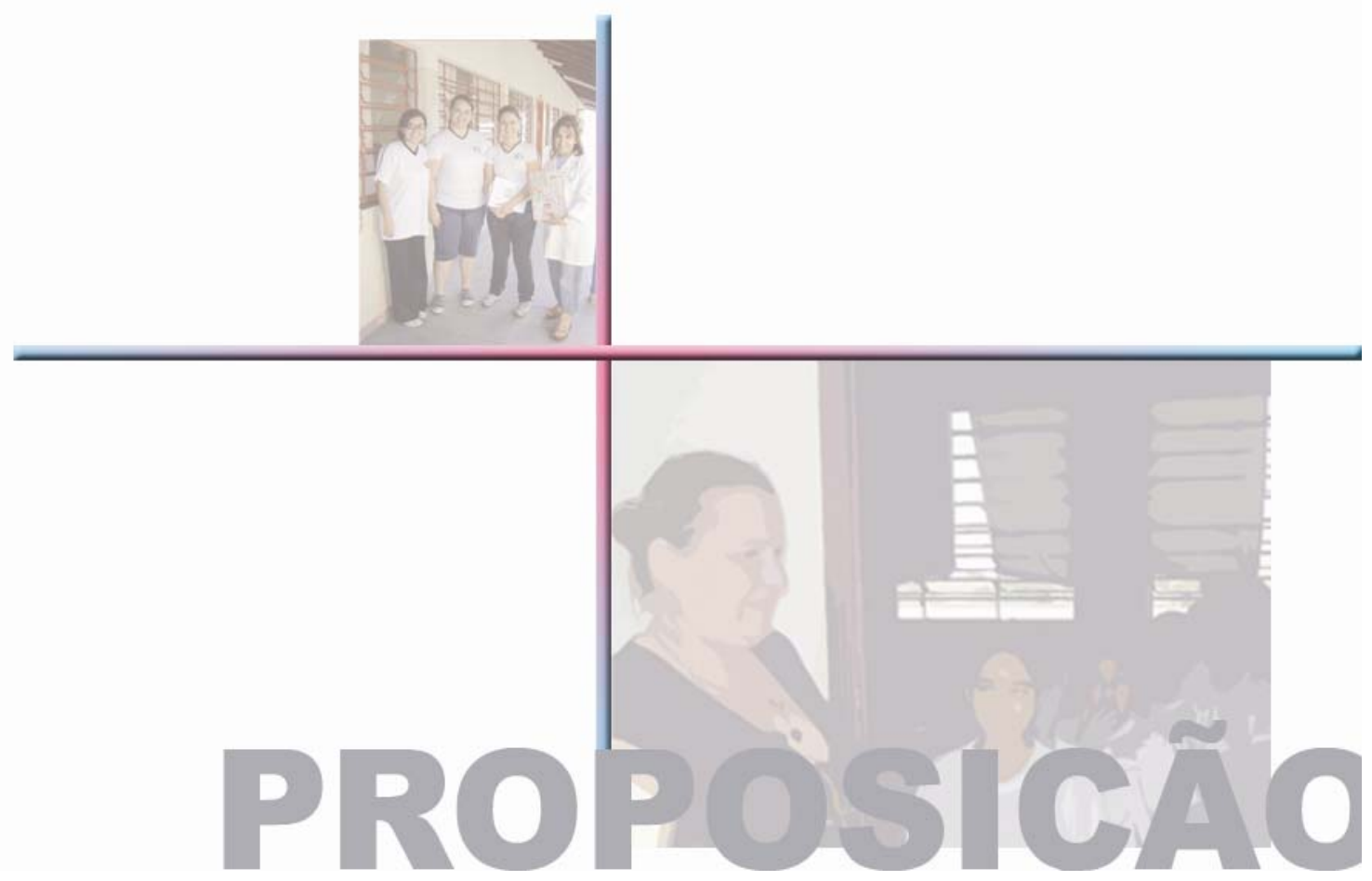

PROPOSIÇÃO 


\section{3 - PROPOSIÇÃO}

O presente trabalho apresenta objetivos gerais e objetivos específicos.

\subsection{Objetivos Gerais.}

Esse trabalho visou verificar o grau de conhecimento dos professores das escolas públicas de ensino fundamental, da $1^{\mathrm{a}}$ à $4^{\mathrm{a}}$ série, do município de Bauru-SP, sobre saúde bucal, e como tem sido a atitude do profissional em relação à promoção de saúde bucal e educação em saúde na sala de aula.

\subsection{Objetivos específicos.}

Foram avaliados aspectos sobre prevenção em odontologia, e comportamentos como: hábitos saudáveis, origem do conhecimento em saúde bucal, atitudes preventivas e imediatas, e conceitos sobre traumatismos dentais. 


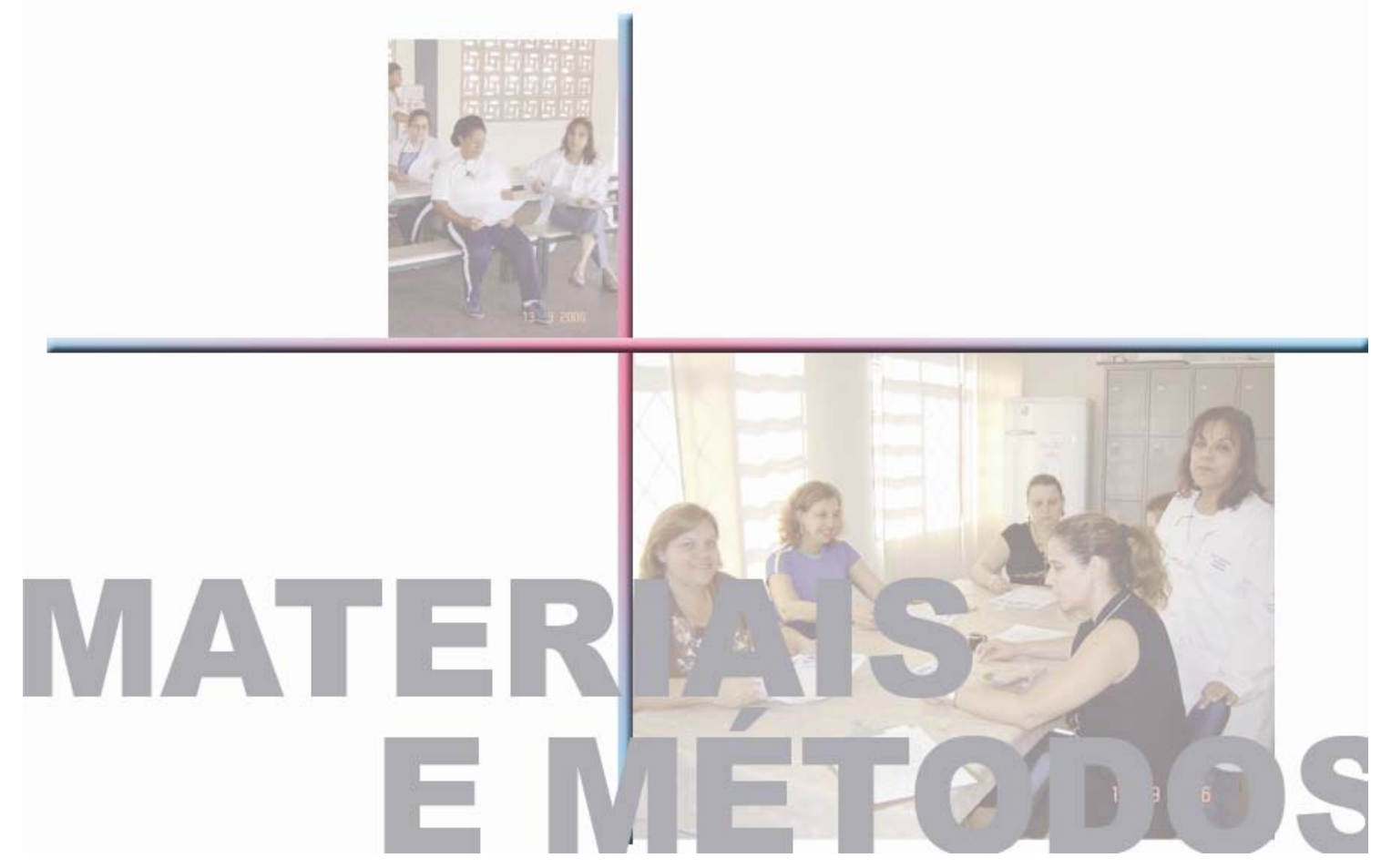

MATERIAIS E MÉTODOS 


\section{4 - MATERIAIS E MÉTODOS}

Inicialmente foram enviadas cópias do projeto da pesquisa intitulado "Avaliação do conhecimento em saúde bucal, dos professores de escolas da rede pública de Bauru", sendo acompanhados de ofícios anexos, informando sobre a necessidade do estudo e também solicitando autorização para a realização da pesquisa nas escolas. Esses ofícios e projetos da pesquisa foram endereçados para a Delegacia Regional de Ensino em Bauru, que administra as escolas estaduais, e para a Secretaria Municipal de Educação de Bauru, que administra escolas municipais, $e$ as duas Instituições aprovaram a realização da pesquisa nas suas escolas.

A Delegacia Regional de Ensino de Bauru autorizou a realização da pesquisa com os professores em 10 das 51 escolas estaduais. A localização foi determinada estrategicamente através da visualização de um mapa da cidade de Bauru com as demarcações das escolas. Considerou-se, para a escolha das 10 escolas (número autorizado), aquelas que fossem situadas em regiões periféricas mais distantes do centro da cidade, e também a possibilidade de atingir crianças de classe social menos favorecida. A Secretaria Municipal de Educação permitiu a realização da pesquisa em todas as suas 14 escolas municipais.

Este trabalho teve o seu projeto de pesquisa enviado e aprovado pelo Comitê de Ética em Pesquisa em seres Humanos da Faculdade de Odontologia de Bauru, Universidade de São Paulo, protocolo de aprovação $n^{\circ}$ $82 / 2005$. 
O cenário do estudo teve seu local em 24 escolas da rede pública de ensino fundamental do município de Bauru, situado no interior de São Paulo. O público alvo pesquisado foi um conjunto de 317 professores de $1^{\text {a }}$ à $4^{a}$ Série, do ensino fundamental, em 2005.

A cidade de Bauru possui cerca de 365.000 habitantes e um contingente de 51 escolas estaduais de ensino fundamental com um total de 1500 professores, e 14 escolas municipais de ensino fundamental com um total de 191 professores.

Para realizar as entrevistas com os professores das escolas, um contato antecipado foi feito com cada diretora e coordenadora pedagógica, marcando as datas e horários possíveis para visitar cada escola. A pesquisa foi executada durante os meses de outubro de 2005 a fevereiro de 2006.

O total da amostra inicial de pesquisados foi de 317 professores, composto por $19 \%$ dos professores das escolas estaduais e $76 \%$ dos professores das escolas municipais. Utilizou-se a técnica de entrevista individual, com o cuidado de não influenciar nenhuma resposta. Para isso nenhuma informação ou explicação ou resposta foi dada durante a entrevista, apenas anotando as respostas dos participantes. Ficou acordado que o esclarecimento de dúvidas e explicações seria realizado ao final de cada entrevista aplicada. Como instrumento da pesquisa foi utilizado um questionário, elaborado com 20 questões abertas e fechadas (anexo 6).

As questões abordavam dados relativos à caracterização da amostra, comportamentos e atitudes em saúde bucal, conhecimentos em saúde bucal, conceituações etiológicas das doenças bucais, conhecimentos das medidas preventivas em saúde bucal, existência de manual de saúde geral e bucal na escola e conhecimento sobre traumatismo dental. 
Um documento de termo com consentimento livre e esclarecido foi assinado voluntariamente pelos pesquisados. (anexo 5).

Para favorecer o entendimento do local onde as escolas se situam nos diversos bairros da cidade, um mapa da cidade de Bauru (executado pelo setor Geo-processamento de dados do DAE-Bauru) possibilitou a localização das escolas.

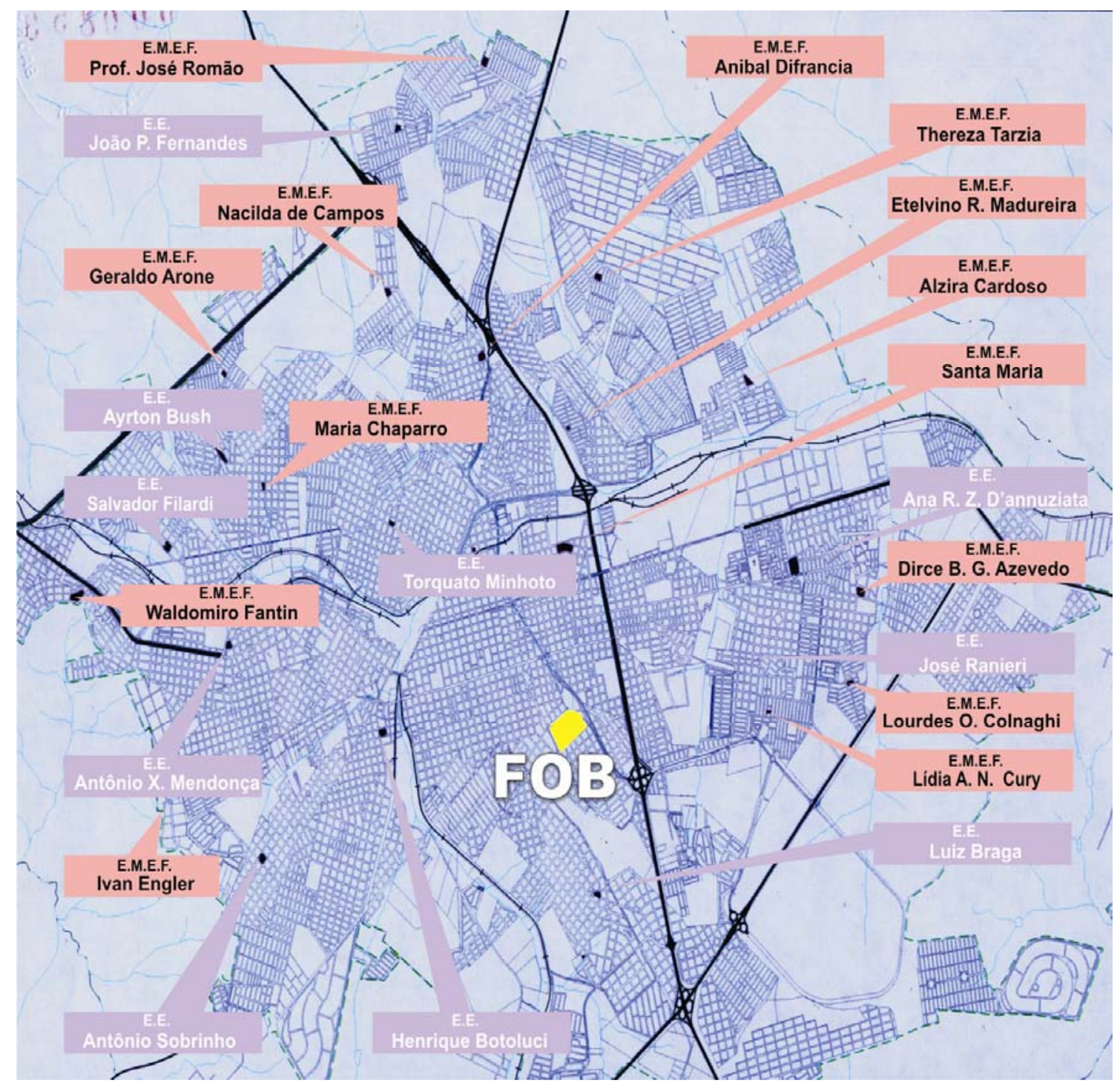

Legenda do mapa da cidade de Bauru - E.M.E.F Escolas Municipais visitadas, E.E. Escolas Estaduais visitadas

Figura 1 - Mapa da cidade de Bauru, com localização das escolas públicas pesquisadas. 
Nesse mapa, a localização das escolas pesquisadas podem ser visualizadas pelos pontos demarcados, onde se encontram respectivamente os nomes das escolas. Como ponto referencial, assinalou-se de amarelo a quadra onde se localiza a Faculdade de Odontologia de Bauru.

Observou-se que alguns professores não estavam presentes no dia da entrevista, por licença de saúde ou abono do dia de trabalho. Professores que lecionavam em outras escolas da cidade, caso já tivessem respondido a essa mesma pesquisa, em outra escola, não eram novamente entrevistados.

A dificuldade encontrada durante a entrevista foi o fato de limitações do tempo para realizar os questionamentos, visto que por vezes a pesquisa foi realizada no horário de intervalo dos professores (20 minutos), em outras ocasiões realizada dentro da sala de aula para evitar as saídas do professor da sala, ou então encaixado em horário na reunião dos professores, o que acarretou além do tempo limitado, muitas interrupções durante a aplicação do questionário, quando realizado dentro da sala de aula.

As respostas foram coletadas e agrupadas por assuntos: caracterização da amostra (tipo da escola, gênero, faixa etária, tempo de serviço, renda familiar), comportamentos e atitudes em saúde bucal, conhecimentos em saúde bucal, conceituações etiológicas em saúde bucal, existência de manual de saúde geral e bucal na escola e conhecimento sobre traumatismo dental. A pesquisa utilizou o método quanti-qualitativo de análise dos dados, e a descrição dos resultados foi feita por meio de tabelas e gráficos com freqüências absolutas e relativas.

Sendo de 1691 professores o universo a ser estudado, uma amostra de 307 professores proporcionaria 
uma margem de erro de, no máximo $5 \%$, para um nível de confiança de $95 \%$. 


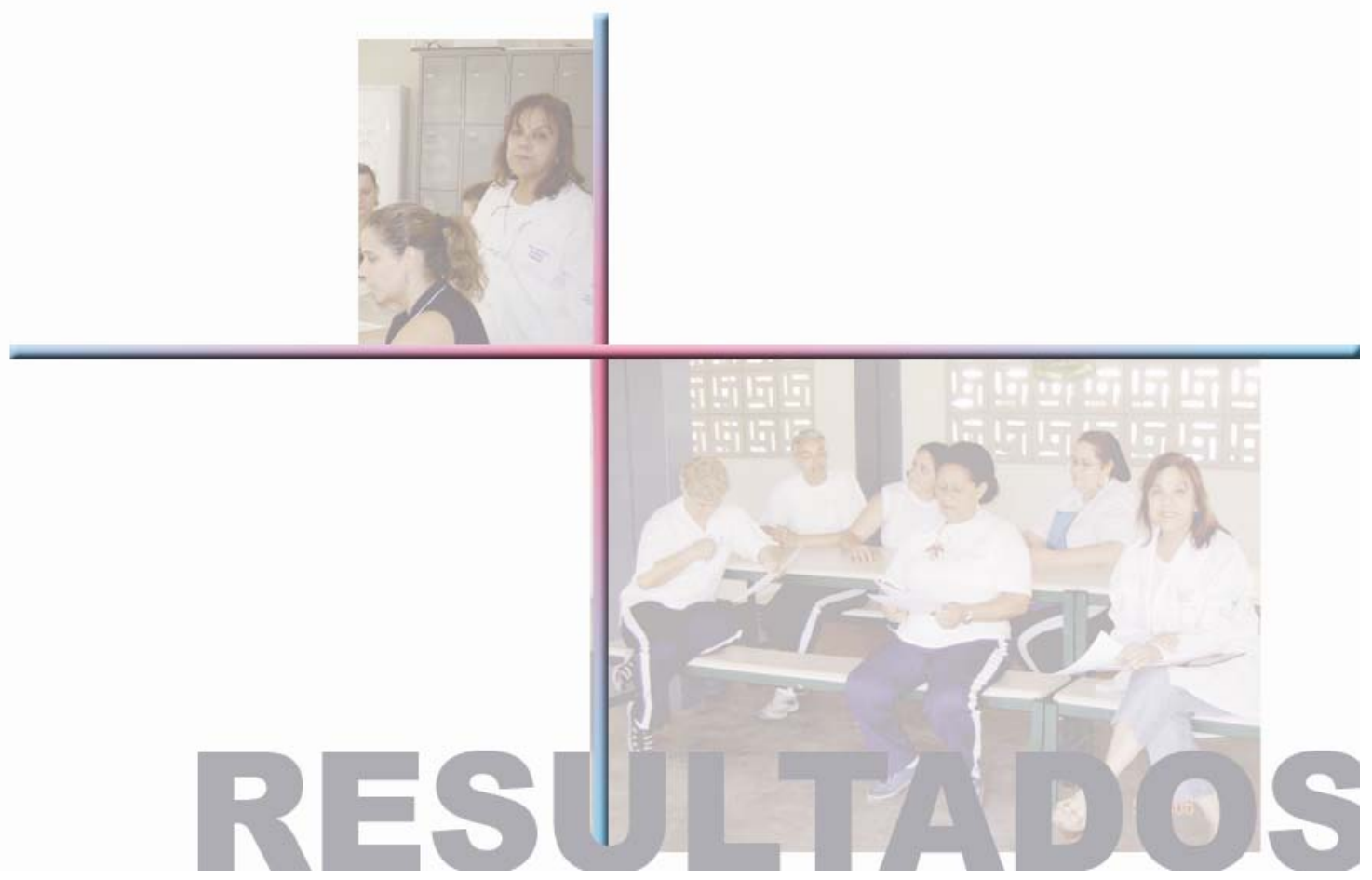

RESULTADOS 
5 - RESULTADOS

Os resultados estão apresentados, a seguir, divididos em seus itens de acordo com o tema de cada questão.

5.1. Caracterização da amostra.

Buscou-se caracterizar a amostra classificando os tipos de escolas onde os professores atuam, a predominância de gênero, bem como grupo etário, escolaridade, tempo de serviço e renda familiar, conforme demonstrado nas tabelas abaixo:

Tabela 1 - Número de professores pesquisados.

\begin{tabular}{lcc}
\hline Tipo de escola & $\mathbf{n}$ & $\%$ \\
\hline Municipal & 147 & 47,88 \\
Estadual & 160 & 52,12 \\
\hline Total & 307 & 100,00 \\
\hline
\end{tabular}

Foram pesquisados 307 professores de escolas estaduais e municipais (tabela 1 ), sendo $147(47,88 \%)$ dos pesquisados de escolas municipais, 160 (52,12\%) de escolas estaduais, atingindo $76,96 \%$ dos professores das escolas municipais e $10,67 \%$ dos professores das escolas estaduais, totalizando $18,15 \%$ do efetivo de professores da rede pública de ensino fundamental do município de Bauru, conforme demonstrado na tabela 2 . 
Rute Moreira de Freitas Sant'Anna

Tabela 2 - Número de professores na rede pública do município de Bauru

\begin{tabular}{lccc}
\hline Tipo de escola & n-Total & n- Amostra & $\%$ \\
\hline Muricipal & 191 & 147 & 76,96 \\
Estadual & 1500 & 160 & 10,67 \\
\hline Total & 1691 & 307 & 18,15 \\
\hline
\end{tabular}

O município de Bauru possui, na rede pública de ensino fundamental, 14 escolas municipais e 51 estaduais. Para a realização desta pesquisa solicitou-se junto aos órgãos competentes, Secretaria Municipal de Educação e Delegacia Regional de Ensino, autorização para a realização da mesma, sendo que a Delegacia Regional de Ensino somente autorizou realizar a pesquisa em 10 escola estaduais, o que justifica o percentual menor de pesquisados nas escolas estaduais.

$\mathrm{Na}$ tabela 3, buscou-se a classificação do gênero para conhecer a qual predominância de professores nas escolas nesse aspecto.

Tabela 3 - Número de professores por gênero.

\begin{tabular}{lcc}
\hline Gênero & $\mathbf{n}$ & \% \\
\hline Feminino & 300 & 97,72 \\
Masculino & 7 & 2,28 \\
\hline Total & 307 & 100,00 \\
\hline
\end{tabular}

De acordo com a tabela 3, demonstrou-se o que é comum observar nas escolas de ensino fundamental, a maioria constituída por professores do gênero feminino, neste trabalho em questão, 97,71\%. No grupo do gênero masculino houve representatividade bem menor, constituída por 2,28\% professores. Os resultados da investigação por faixa etária ou idade mostraram que a concentração maior de professores 
respondeu estar na faixa etária entre 30 a 49 anos, constituída por $195(63,52$ \%) dos participantes. Na faixa etária de 50 anos ou mais, os dados mostraram 71 professores ou $23,13 \%$ da amostra. Nas outras faixas etárias houve uma concentração de menor representatividade gradativa observada na tabela 4.

Tabela 4 - Porcentagem de professores por faixa etária.

\begin{tabular}{lcc}
\hline Idade & $\mathbf{n}$ & $\mathbf{\%}$ \\
\hline 19 a 29 anos & 41 & 13,36 \\
30 a 49 anos & 195 & 63,52 \\
50 a 59 anos & 61 & 19,87 \\
Mais de 60 anos & 10 & 3,26 \\
\hline Total & 307 & 100,00 \\
\hline
\end{tabular}

Verificou-se que o grupo de faixa etária acima de 60 anos de idade responde por apenas $3.26 \%$, já o dos professores mais jovens totalizam 13,36\% da amostra (tabela $4)$.

Com relação ao tempo de serviço no magistério dos professores, mostrou-seque grande parte de professores, 168 $(54,72 \%)$, foram classificados na faixa entre 11 a 20 anos de tempo de serviços prestados à rede pública de educação (tabela 5)

Notou-se também que 78 professores $(25,41 \%)$ estavam iniciando a carreira, ou seja, com menos de 10 anos lecionando. Outro grupo a destacar são os que estavam na faixa entre 21 a 30 anos de tempo serviço profissional, totalizando $18,24 \%$. Observou-se ainda que $1,63 \%$ dos profissionais pesquisados estavam com mais de 30 anos de serviço, conforme demonstra tabela 5 . 
Tabela 5 - Porcentagem de professores por tempo de serviço.

\begin{tabular}{lcc}
\hline Tempo de serviço & $\mathbf{n}$ & $\%$ \\
\hline 1 a 10 anos & 78 & 25,41 \\
11 a 20 anos & 168 & 54,72 \\
21 a 30 anos & 56 & 18,24 \\
Mais de 30 & 5 & 1,63 \\
\hline Total & 307 & 100,00 \\
\hline
\end{tabular}

Quando o questionamento foi direcionado a responderem sobre a renda familiar, observaram-se resultados tais como: 60,26\% dos entrevistados, ou seja, 185 docentes classificaram-se na faixa de renda familiar entre um a três mil reais, de acordo com a tabela 6 .

Tabela 6 - Classificação da renda familiar.

\begin{tabular}{lcc}
\hline Renda familiar & $\mathbf{n}$ & $\%$ \\
\hline 400 a 1 mil reais & 69 & 22,48 \\
1 mil a 3 mil reais & 185 & 60,26 \\
3 mil a 6 mil reais & 44 & 14,33 \\
6 mil a 9 mil reais & 8 & 2,61 \\
Acima de 9 mil reais & 1 & 0,33 \\
\hline Total & 307 & 100,00 \\
\hline
\end{tabular}

Outra informação obtida foi a que $22,48 \%$ ou 69 professores responderam estar na faixa de renda salarial de menor poder aquisitivo, sendo esta entre quatrocentos reais a um mil reais. Responderam estar na faixa de renda familiar entre três mil reais a seis mil reais um grupo de 44 professores, ou seja, $14,33 \%$ da amostra. E ainda 8 professores ou $2,61 \%$ se classificaram com renda entre seis a nove mil reais, e apenas 1 professor ou $0,32 \%$ respondeu estar na faixa de maior poder aquisitivo dentro da pesquisa sendo mais de nove mil reais.

Com respeito à avaliação do nível escolaridade, constatou-se que a maioria dos entrevistados, 196 
professores, respondeu afirmativamente ter curso superior, correspondendo a um percentual de $63,84 \%$ dos pesquisados, conforme demonstra tabela 7 .

Tabela 7 - Número de professores por nível de escolaridade.

\begin{tabular}{lcc}
\hline Nível de Escolaridade & $\mathbf{n}$ & $\%$ \\
\hline Mestrado & 3 & 0,98 \\
Especialização & 64 & 20,85 \\
Superior & 196 & 63,84 \\
Magistério & 44 & 14,33 \\
\hline Total & 307 & 100,00 \\
\hline
\end{tabular}

De acordo com essa tabela, se forem agrupados os professores com curso de especialização, curso superior e mais curso mestrado, perfazem 85,67\%, (263) com nível de escolaridade mais diferenciado. Por outro lado, ainda $14,33 \%$ (44) referiram ter cursado somente o magistério.

5. 2. Comportamento e atitudes em saúde bucal.

Para essa avaliação, perguntaram-se questões relativas aos seus hábitos de higiene bucal: tempo de troca das escovas, características adequadas das escovas, freqüência de escovação diária, levar escovas de dente para o trabalho.

Quando questionado sobre quanto a trocar regularmente as escovas dentais, todos os entrevistados responderam que trocavam regularmente suas escovas, correspondendo a $100 \%$ dos entrevistados.

Com respeito ao tempo que demoravam em trocar suas escovas de dente, a maioria, ou seja, $77,20 \%$ dos professores responderam que costumavam trocar suas escovas no período de 1 a 3 meses, seguidos de 16,94\% dos que costumam trocar as escovas a cada 4 a 6 meses, e 
apenas $0,98 \%$ acima de 6 meses. Notou-se que $4,89 \%$ estavam sem respostas ( tabela 8 ).

Tabela 8 - Tempo de troca das escovas de dentes.

\begin{tabular}{lcc}
\hline Tempo de troca da escova & $\mathbf{n}$ & $\%$ \\
\hline 1 a 3 meses & 237 & 77,20 \\
4 a 6 meses & 52 & 16,94 \\
Acima de 6 meses & 3 & 0,98 \\
Sem resposta & 15 & 4,89 \\
\hline Total & 307 & 100,00 \\
\hline
\end{tabular}

Questionou-se, em seguida, se o docente tinha costume de levar a escova de dentes para o trabalho, da amostra $51,47 \%$, responderam que sim, porém outro grupo de professores afirmaram não levar a escova de dentes no trabalho, totalizando $48,53 \%$ dos entrevistados (tabela 9).

Tabela 9 - Levar a escova de dentes para o trabalho.

\begin{tabular}{lcc}
\hline Levar escova de dentes para o trabalho & $\mathbf{n}$ & \% \\
\hline Sim & 158 & 51,47 \\
Não & 149 & 48,53 \\
\hline Total & 307 & 100,00 \\
\hline
\end{tabular}

O número de escovações diárias foi avaliado, sendo que a maioria, $44 \%$, respondeu que fazia suas escovações em média 4 vezes ao dia, seguido dos que realizam as escovações 3 vezes ao dia (28\%), 5 vezes ao dia (16\%), 6 vezes ao dia (2\%), 2 vezes ao dia (1\%). E 9\% estavam sem respostas (figura 2). 


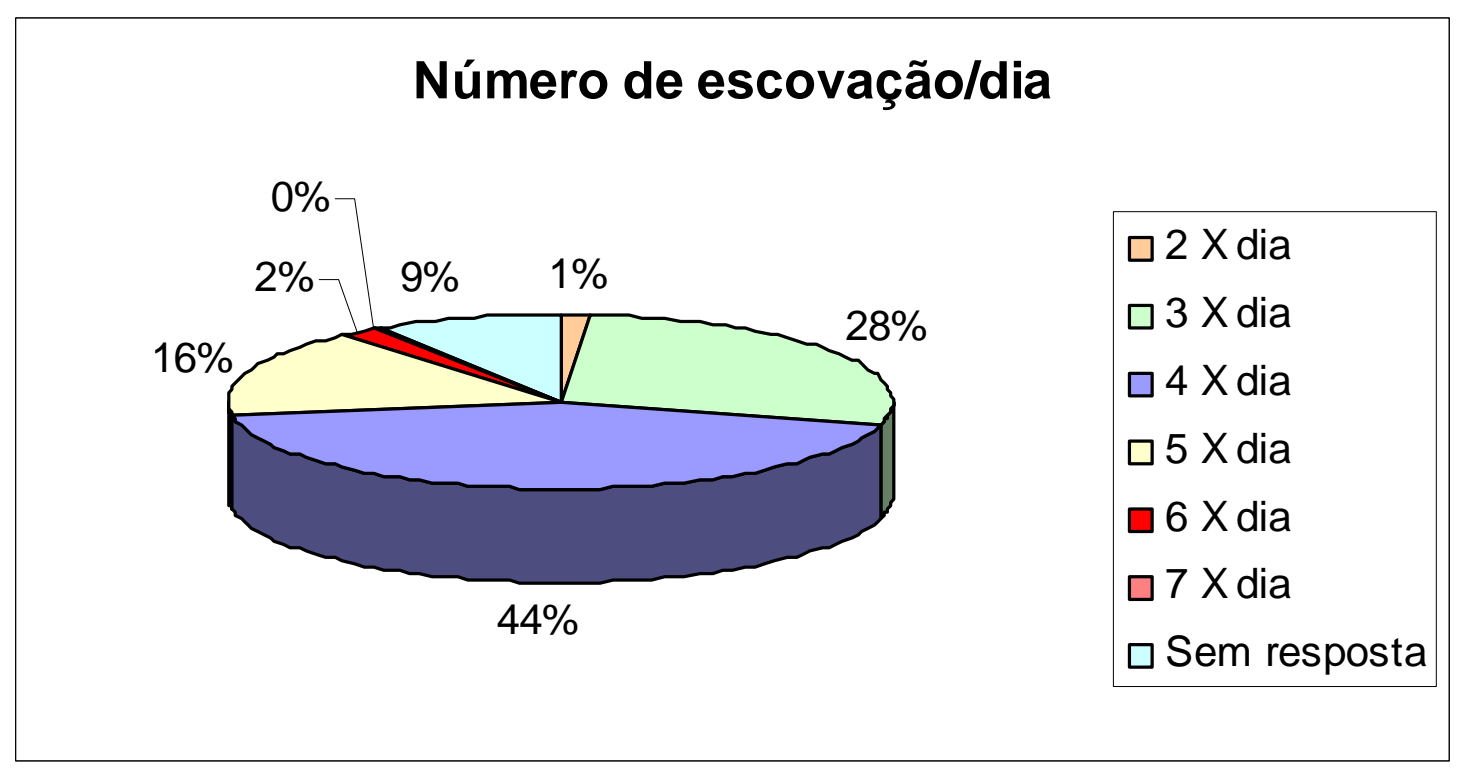

Figura 2 - Número de escovação por dia.

A preferência dos professores sobre escovas dentais foi investigada, sendo questionado qual tipo (ou característica) de escova escolhiam quando compravam. A maioria $77,00 \%$ (231) dos professores respondeu ter preferência pelas escovas com cerdas macias. Já 9,33\% (28) preferiam escovas com cerdas médias e 3,33\% (10) referiram preferir escovas com cerdas duras. Com referência ao tipo de cabeça da escova, 24,66\% (71) citaram escovas de cabeça média, já outros $21,66 \%$ (65) tinham preferência por escovas de cabeça pequena e $2,66 \%$ (8) escovas de cabeça grande (Tabela 10). 
Tabela 10 - Características das escovas dentais.

\begin{tabular}{lcc}
\hline Características das escovas dentárias & $\mathbf{n}$ & $\mathbf{\%}$ \\
\hline Cerdas macias & 231 & 77,00 \\
Cerdas médias & 28 & 9,33 \\
Cerdas duras & 10 & 3,33 \\
Cabeça grande & 8 & 2,66 \\
Cabeça média & 71 & 24,66 \\
Cabeça pequena & 65 & 21,66 \\
Outros & 23 & 7,66 \\
\hline
\end{tabular}

Nas respostas classificadas como outros, alguns professores citaram características bem diferentes como: usavam escovas elétricas, tinham que ser de bom preço, as mais em conta, usavam as escovas que o farmacêutico indicava, ou escolhiam pelas marcas mais famosas, só tipo Oral-B.

5. 3. Conhecimentos em saúde bucal.

As informações e atitudes do professor em sala de aula e abordagens sobre saúde geral e bucal para seus alunos foram investigadas, questionando-se primeiro se 0 professor falava sobre saúde geral na sala de aula, como também orientações referentes a como escovar os dentes, e se alguém mais fazia essa orientação na escola, e se especificamente falavam da importância em saúde bucal na sala de aula. Foi também investigada a origem das informações em saúde bucal e se fizeram algum treinamento em saúde bucal.

Tabela 11 - Abordagem do tema saúde geral em sala de aula.

\begin{tabular}{lcc}
\hline Saúde geral & $\mathbf{n}$ & \% \\
\hline Sim & 300 & 97,72 \\
Não & 7 & 2,28 \\
\hline Total & 307 & 100,00 \\
\hline
\end{tabular}


Verificou-se que 97,72\% (300) referiram que falavam de saúde geral para os alunos na sala de aula. Alguns explicavam que, sempre que surgia oportunidade, falavam sobre a saúde geral. Os demais 2,28\% (7) responderam que não tinham tempo ou oportunidade ou não era sua parte falar sobre saúde geral para os alunos, ou então não tinham material apropriado para esse assunto(tabela 11).

Ainda na entrevista foi investigado se o professor costumava falar especificamente da importância da saúde bucal para os alunos, grande maioria, 92,51\% (284), respondeu que sim, sempre falavam da importância de se ter saúde bucal. Já 6,84\% (21) responderam que não falavam da importância da saúde bucal, conforme dados demonstrados na tabela 12.

Tabela 12 - Abordagem do tema saúde bucal em sala de aula.

\begin{tabular}{lcc}
\hline Tema saúde bucal & $\mathbf{n}$ & $\%$ \\
\hline Sim & 284 & 92,51 \\
Não & 21 & 6,84 \\
Sem resposta & 2 & 0,65 \\
\hline Total & 307 & 100,00 \\
\hline
\end{tabular}

Perguntou-se em seguida aos professores se ensinavam os alunos em aulas como fazer higiene bucal. Verificou-se que (224) $72,96 \%$ dos entrevistados responderam que davam orientações sobre como fazer higiene bucal, e (82) $26,71 \%$ dos professores responderam que não faziam nenhuma orientação de higiene bucal. Desse restante, alguns justificavam afirmando que não tinham material para ensinar ou não tinham tempo (tabela 13). 
Tabela 13 - Orientações sobre higiene bucal em sala de aula.

\begin{tabular}{lcc}
\hline Higiene bucal & $\mathbf{n}$ & $\%$ \\
\hline Sim & 224 & 72,96 \\
Não & 82 & 26,71 \\
Sem resposta & 1 & 0,33 \\
\hline Total & 307 & 100,00 \\
\hline
\end{tabular}

Investigou-se se alguém mais na escola fazia esse tipo de orientação aos alunos sendo que 42,02\% (129) dos professores responderam que a escola não tinha ninguém para orientar, 38,76\% (119) responderam que a escola tinha dentista ou a auxiliar de dentista orientava higiene bucal. $19,22 \%$ (59) estavam sem respostas (tabela 14).

Tabela 14 - Orientações sobre higiene bucal realizadas por outro profissional.

\begin{tabular}{lcc}
\hline Orientações por outro profissional & $\mathbf{n}$ & $\mathbf{\%}$ \\
\hline Sim & 119 & 38,76 \\
Não & 129 & 42,02 \\
Sem resposta & 59 & 19,22 \\
\hline Total & 307 & 100,00 \\
\hline
\end{tabular}

A origem do conhecimento em saúde bucal foi investigada quando se questionou de onde eles tinham recebido as informações que passavam para os alunos, (tabela15). 
Tabela 15 - Origem do conhecimento em saúde bucal.

\begin{tabular}{lcc} 
Origem do conhecimento em saúde bucal & $\mathbf{n}$ & $\mathbf{\%}$ \\
\hline Dentista & 155 & 50,49 \\
Escola & 123 & 40,07 \\
Mídia & 82 & 26,71 \\
Família & 70 & 22,80 \\
Cursos & 52 & 16,94 \\
Livros & 42 & 13,68 \\
Outros & 45 & 14,66 \\
\hline
\end{tabular}

Observou-se que $50,49 \%$ (155) responderam que receberam informações dos seus dentistas, 40,07\% (123) mencionaram as escolas, $26,71 \%$ (82) pela mídia impressa e falada, $22,80 \%$ (70) ser de origem da família, e havia respostas onde mencionaram 16,94\% (52) cursos, 13,68\% (42) livros. As que foram classificadas como "outros" representavam $14,66 \%$ (45) dos professores, mencionavam médico, foi agente comunitário, já trabalhou na saúde, no dia a dia, (tabela 15).

Para explorar esse questionamento, indagou-se se o professor tinha recebido ou participado de algum treinamento sobre saúde bucal. 


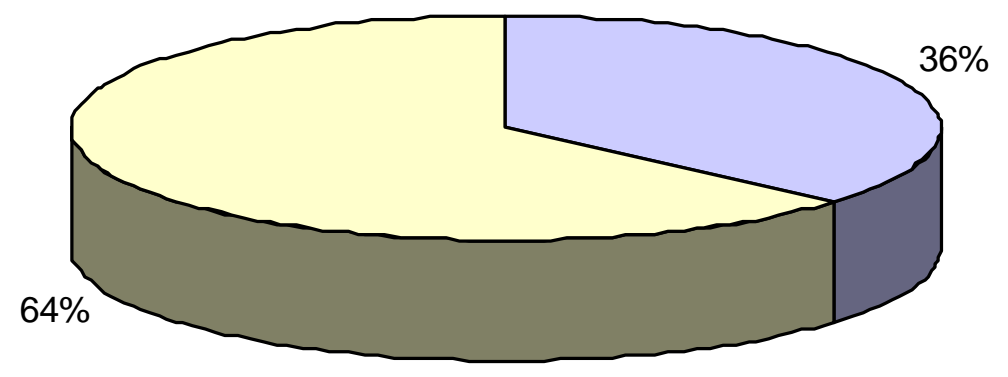

Figura 3 - Professores que participaram de treinamento sobre saúde bucal.

Tabela 16 - Porcentagem do tipo de treinamento $(n=112)$ que os professores participaram.

\begin{tabular}{lcc}
\hline Tipo de treinamento & $\mathbf{n}$ & $\%$ \\
\hline dentista/escola & 64 & 57,14 \\
cursos/palestras & 60 & 53,57 \\
dentista/particular & 21 & 18,75 \\
\hline
\end{tabular}

Observou-se, que a maioria dos professores $64 \%$ (195) afirmaram não ter recebido nenhum treinamento, e $36 \%$ (112) deles responderam que sim (figura 3). Completando essa pergunta, investigou-se os que responderam afirmando ter recebido treinamento, onde esse treinamento foi realizado, e $64(57,14 \%)$ professores responderam ser dentistas da escola ou então acadêmicos ou dentistas que vinham às vezes na escola, $60(53,57 \%)$ professores responderam que tinham assistido a cursos elou palestras, alguns explicavam que tinham feito um treinamento em pré-escolas, pois lá palestras e cursos são realizados com maior freqüência. Outros 21 
professores, ou seja, $18,75 \%$ citaram seus dentistas particulares (tabela 16).

5. 4. Conceituações etiológicas das doenças bucais.

Um questionamento bastante importante para a avaliação do conhecimento dos professores foi questão "quais as razões para manter a boa higiene bucal?", quando as noções sobre etiologia da cárie dentária bem como da doença periodontal puderam ser investigadas.

Tabela 17 - Conhecimento dos professores quanto às razões para manter a boa higiene bucal.

\begin{tabular}{lcc}
\hline Razões para boa higiene bucal & $\mathbf{n}$ & $\%$ \\
\hline Saúde & 173 & 56,35 \\
Estética & 76 & 24,76 \\
Bom Hálito & 71 & 23,13 \\
Prevenção de doenças & 44 & 14,33 \\
Prevenção à cárie & 42 & 13,68 \\
Conservar dentes & 40 & 13,03 \\
Higiene & 30 & 9,77 \\
Mastigação & 27 & 8,79 \\
Relacionamento com pessoas & 22 & 1,17 \\
Prevenção da doença periodontal & 13 & 4,23 \\
Outros & 6 & 1,95 \\
\hline
\end{tabular}

As razões ou motivos para manter boa higiene bucal foram pesquisadas, e todos os 307 (100\%) professores responderam afirmativamente que sabiam as razões para manter boa higiene bucal. Ao explicarem essas razões, muitos deram mais de uma resposta, sendo que a maioria, 173 $(56,35 \%)$ professores, responderam a saúde como primeira razão. Em seguida citaram 76 (24,76\%) para ter estética, 71 $(23,13 \%)$ para ter bom hálito, 44 (14,33\%) prevenção de doenças (cardíacas, respiratórias, câncer), 42 (13,68\%) 
citaram prevenção à cárie, e $40(13,03 \%)$ professores referiram-se à conservação dos dentes. Para as citações higiene, mastigação, relacionamento com pessoas, prevenção à doença periodontal, foram observados menos de $10 \%$ em cada citação. A citação "outros" foi respondida por 6 (1,95\%), e constou de respostas diferentes tais como: é bom para o estômago, traz conseqüências, saúde começa pela boca, é fundamental (tabela 17).

Sabe-se que crianças na idade escolar, por vezes, apresentam sangramento gengival e deficiências de escovações dentárias. O professor, por ser um grande colaborador, pode identificar essas necessidades e auxiliar as crianças nas práticas de escovação supervisionada, porque ele está diariamente com a criança. Se a criança aprender na escola a escovar seus dentes corretamente, e se for alertada para essa patologia, estará prevenindo no futuro perdas precoces de dentes por doença periodontal.

Com relação à etiologia da doença periodontal, foram abordados aspectos como conhecer doença, 66\% (202), ou seja, a maioria dos entrevistados afirmaram conhecer a doença e 34\% (105) desconheciam (figura 4). 


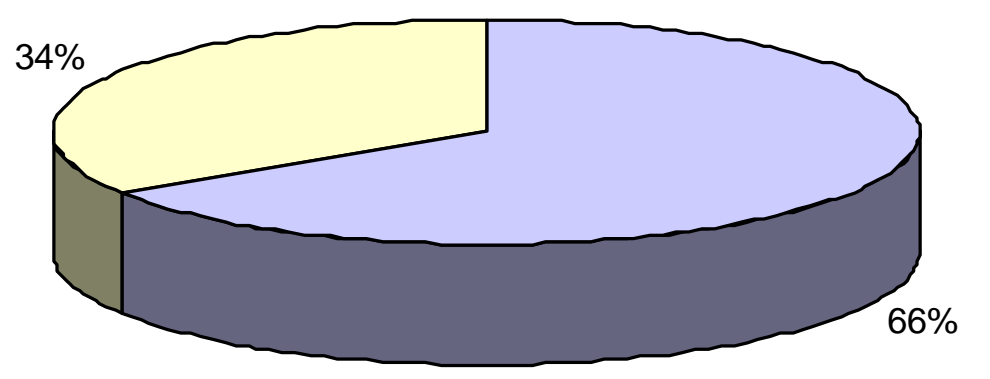

Figura 4 - Porcentagem de professores que conhecem a doença periodontal.

Em relação a esse mesmo assunto investigou-se se sabiam evitar a doença, e 54\% (167) dos professores responderam que sabiam como evitar essa doença bucal, e $46 \%$ (140) responderam que não sabiam (figura 5). Dos que responderam que sabiam como evitar, perguntou-se de que forma evitaria a doença, a maioria, ou seja, 58\% (97) responderam que evitariam tendo boa higiene bucal, 16\% (27) responderam que freqüentar o dentista pode ajudar a evitar a doença, mas apenas 5\% (9) citaram remover a placa dental evita tal doença, e 20\% (34) sem resposta, (figura 6). 


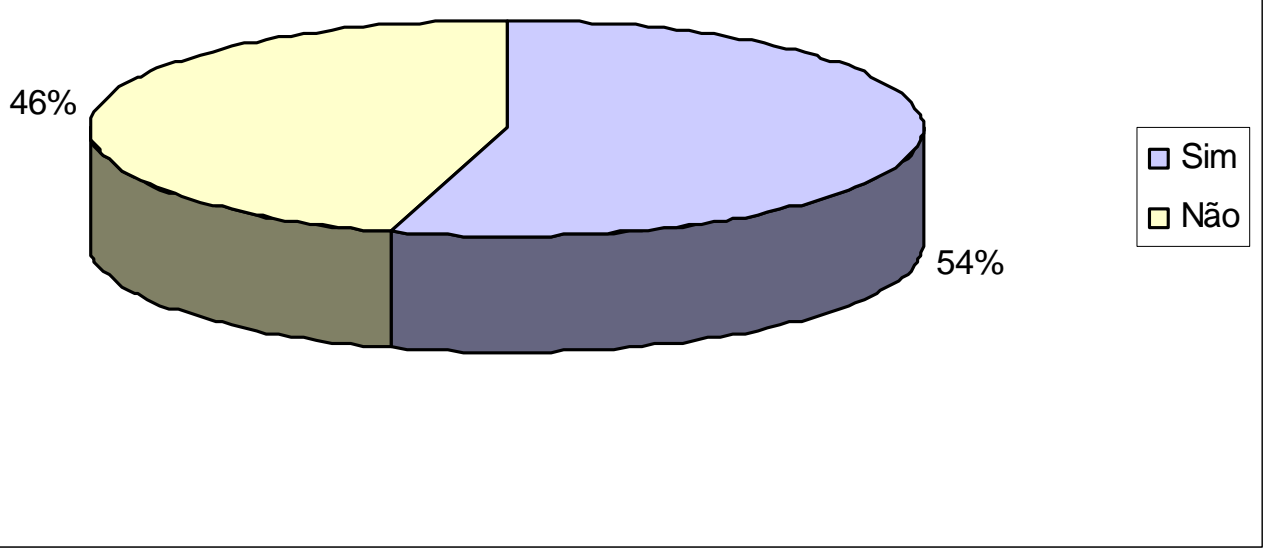

Figura 5 - Porcentagem de professores que sabem evitar a doença periodontal.

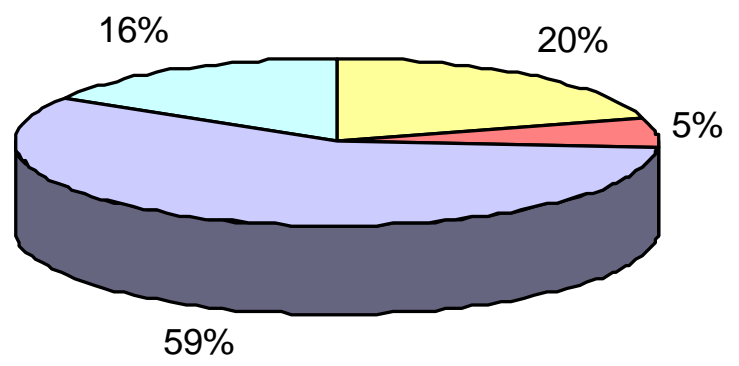

$\square$ sem resposta

$\square$ remover placa dental $\square$ boa higiene bucal

$\square$ frequentar dentista

Figura 6 - Formas de evitar a doença periodontal segundo professores pesquisados.

5. 5. Conhecimento das medidas preventivas em saúde bucal.

Foram feitas perguntas dos principais conceitos específicos sobre o flúor, como sua função e local onde é 
encontrado. Seguindo essa linha de conceitos preventivos, investigou-se também se o professor conhecia a real função do fio dental e também a finalidade do uso de selante. As figuras e tabelas a seguir referem porcentagens correspondentes às respostas da investigação sobre flúor, fio dental e selante.

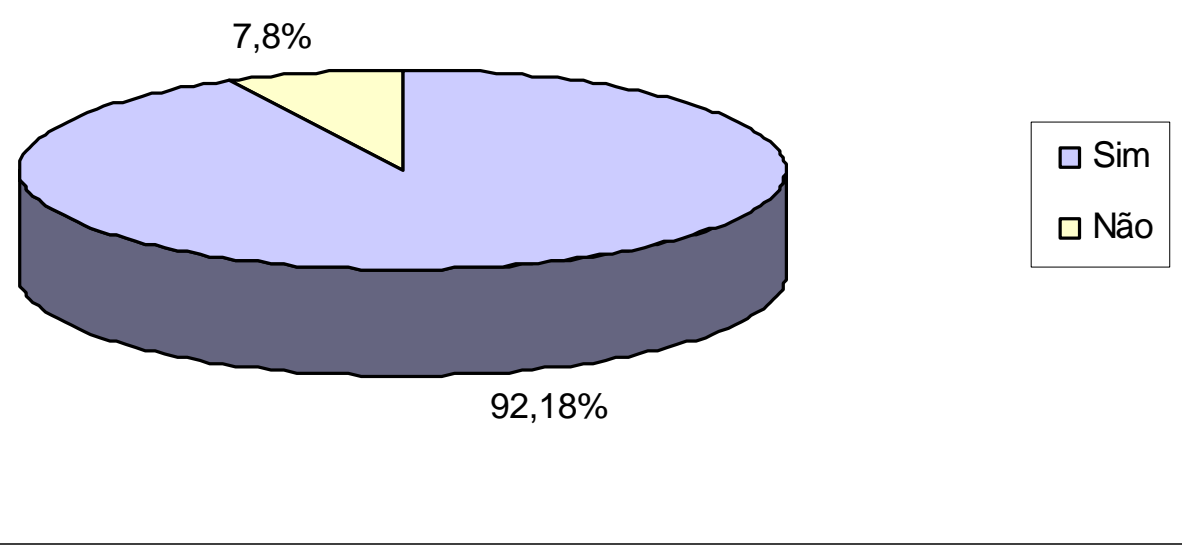

Figura 7 - Conhecimento sobre as funções do flúor.

Sobre os conhecimentos do flúor, verificou-se que $92,18 \%$ (283) dos professores responderam que conheciam as funções do flúor, e apenas $7,8 \%$ (24) responderam negativamente (figura 7). Quando o questionamento foi lembrar as funções do flúor, observaram-se respostas variadas na tabela 18, dentre elas $52,30 \%$ (148) citaram prevenção à cárie, 35,34\% (100) dos professores referiram-se à proteção, $16,61 \%$ (47) fortalecer os dentes, conforme apresentados pela tabela 18 , sendo estas as respostas mais adequadas para as funções do flúor. 
Tabela 18 - Conhecimento sobre as funções do flúor.

\begin{tabular}{lcc}
\hline Funções do flúor & $\mathbf{n}$ & $\%$ \\
\hline Prevenção à cárie & 148 & 52,30 \\
Proteção & 100 & 35,34 \\
Fortalecer dentes & 47 & 16,61 \\
Higienização & 12 & 4,24 \\
Dentes brancos & 10 & 3,53 \\
Hálito puro & 3 & 1,06 \\
Não sabe & 22 & 7,77 \\
\hline
\end{tabular}

As demais citações não respondem adequadamente sobre as funções do flúor; dessas respostas, 7,77\% (22) citaram desconhecer as funções do flúor, 4,24\% (12) referiram higienização, 3,53\% (10) para tornar os dentes brancos, $1,06 \%$ (3) tornar hálito puro (tabela 18).

Quando questionados sobre o conhecimento do local onde se encontra flúor, $89,25 \%$ dos professores (274) citaram que sabiam onde existe flúor, 10,42\% (32) citaram que não sabiam onde existe flúor (tabela 19).

Tabela 19 - Conhecimento do local onde se encontra flúor segundo professores pesquisados.

\begin{tabular}{lcc}
\hline Local do flúor & $\mathbf{n}$ & $\%$ \\
\hline Sim & 274 & 89,25 \\
Não & 32 & 10,42 \\
Sem resposta & 1 & 0,33 \\
Total & 307 & 100 \\
\hline
\end{tabular}

Porém, quando foi solicitado a citar os locais onde se encontram o flúor, as respostas foram bastante diversificadas (tabela 20). 
Tabela 20 - Locais onde se encontra o flúor de acordo com os professores pesquisados.

\begin{tabular}{lcc}
\hline Local onde há fluor & $\mathbf{n}$ & $\%$ \\
\hline Água & 123 & 44,89 \\
Creme dental & 108 & 39,42 \\
Dentistas & 83 & 30,29 \\
Farmácia & 40 & 14,60 \\
Consultórios & 25 & 9,12 \\
Unidades de saúde & 25 & 9,12 \\
Escolas & 22 & 8,03 \\
Alimentos & 14 & 5,11 \\
Não sabe & 28 & 10,22 \\
Outros & 22 & 8,03 \\
\hline
\end{tabular}

Verificou-se nesta tabela (20) sobre acesso ao flúor, que a água de abastecimento foi lembrada por 44,89\% (123) dos entrevistados, flúor no creme dental 39,42\% (108), flúor com os dentistas (consultórios) 30,29\% (83). Essas respostas foram as mais lembradas para acesso ao flúor. Notaram-se diversas citações como 14,60\% (40) em farmácias, colutórios 9,12\% (25), unidades básicas 9,12\% (25), escolas 8,03\%(22), alimentos 5,11\% (14), e também 10,22\% (28) não sabiam como ter o acesso a flúor. As respostas classificadas como "outros" $8,03 \%$ (22) referiam a flúor em: supermercados, lojas de produtos odontológicos, loja de cosméticos. 


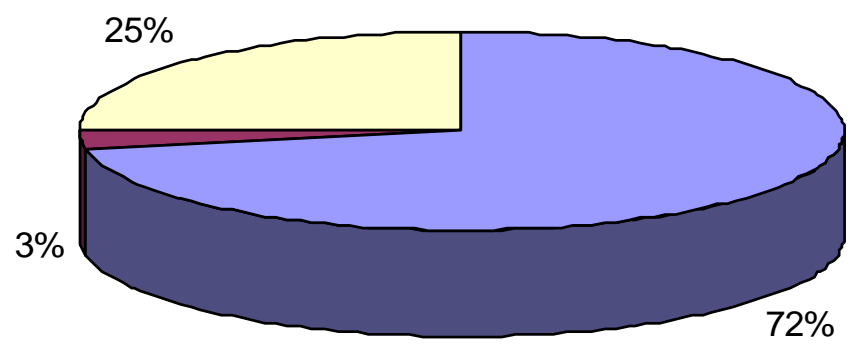

$\square \operatorname{sim}$

uño

$\square$ sem resposta

Figura 8 - Porcentagem de professores que fazem uso do fio dental.

Investigando sobre o uso do fio dental e suas funções, a maioria dos professores, isto é, $72 \%$ (222) dos pesquisados afirmaram fazer uso e apenas $3 \%$ (9) não utilizam o fio dental, justificando pela falta de tempo ou por uso de próteses dentárias 25\% (76) sem resposta, de acordo com a figura 8 .

Quanto às funções do fio dental, apresentadas na tabela 21, 69,06\% (212) dos professores responderam como função principal limpar entre os dentes, 41,37\% (127) remover restos de alimentos e apenas 2,93\% (9) retirar tártaro. Na opção "outros" constituída por 4,3\% (13) dos pesquisados, foram lembradas funções como higiene, proteção e limpar onde a escova não alcança. 
Tabela 21 - Funções do fio dental segundo os professores pesquisados.

\begin{tabular}{lcc}
\hline Função do fio dental & $\mathbf{n}^{\mathbf{0}}$ & $\%$ \\
\hline Limpar entre os dentes & 212 & 69,06 \\
Remover restos de alimentos & 127 & 41,37 \\
Retirar tártaro & 9 & 2,93 \\
Outros & 13 & 4,23 \\
\hline
\end{tabular}

Outro questionamento realizado foi sobre o selante, se os professores pesquisados sabiam o que era (figura 9) e sua função (figura10). Verificou-se que a maioria dos entrevistados, ou seja, 59\% (181) dos docentes desconheciam o que era selante, já $41 \%$ (126) da amostra, afirmaram conhecer.

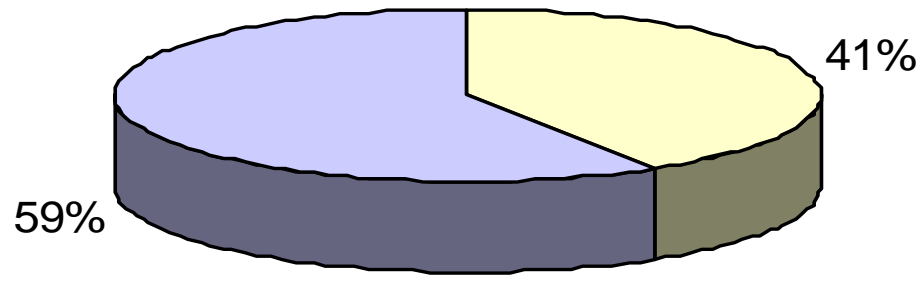

$\square \operatorname{sim}$ $\square$ não

Figura 9 - Porcentagem de professores pesquisados que conheciam selante. 


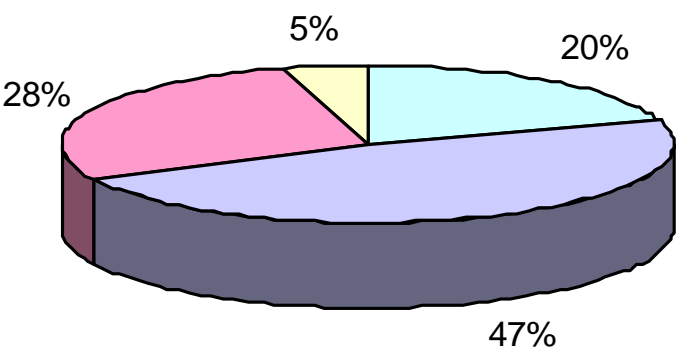

$\square$ prevenção à cárie $\square$ proteção do esmalte $\square$ material sobre o dente $\square$ outros

Figura 10 - Explicação sobre a finalidade selante segundo professores pesquisados.

Aos pesquisados que responderam conhecer selante, perguntou-se se sabiam explicar o que era, sendo referido por 47\% (60) dos professores substância para proteger o esmalte, 28\% (35) um material sobre o dente, e 20\% (25) prevenção à cárie. As respostas caracterizadas como "outros" totalizaram $5 \%$ (6) dos pesquisados, os quais apresentaram no qual citaram respostas diversificadas tais como: algo que passa na obturação, é para não dar tártaro, passa depois da limpeza, usa no dentista, é impermeabilizante do dente (figura 10).

5. 6. Existência de manual de saúde geral e saúde bucal na escola.

Investigou-se ainda se nas escolas existe literatura específica para auxiliar na preparação das aulas de educação e promoção de saúde geral e bucal.

Primeiro foi perguntado ao professor se a escola tinha manual de promoção de saúde geral que pudesse ser usado. Notou-se que 26\% (80) dos professores afirmaram que 
a escola tinha manual de saúde, 39\% (120) mencionaram que a escola não tinha manual, porém 35\% (107) responderam desconhecer a existência de algum manual sobre saúde na escola. Os dados são apresentados na figura 11.

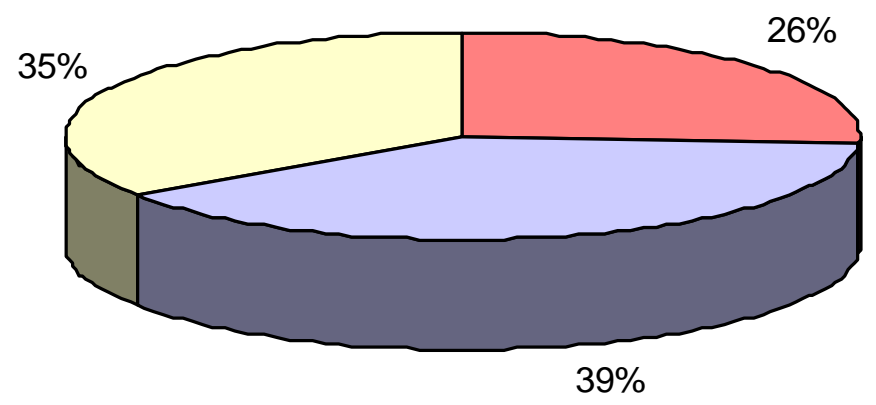

$\square \operatorname{Sim}$

$\square$ Não

$\square$ Não sabe

Figura 11 - Conhecimento sobre a existência de manual de promoção de saúde geral segundo professores pesquisados.

Já sobre o manual de promoção de saúde bucal, somente $21 \%$ (66) responderam que existia este tipo de manual, 43\% (129) responderam que não existia, e 36\% dos professores desconheciam a existência de algum manual sobre saúde bucal (figura 12). 


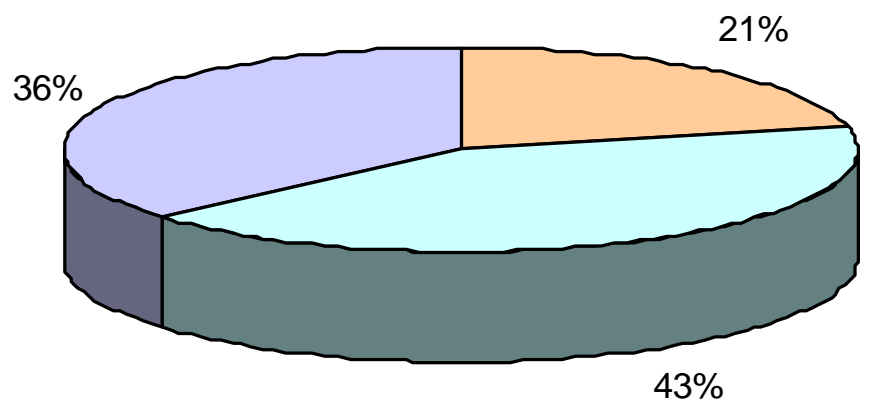

$\square \operatorname{Sim}$

$\square$ Não

$\square$ Não sabe

Figura 12 - Conhecimento sobre a existência de manual de promoção de saúde bucal segundo professores pesquisados.

5. 7. Conhecimento sobre traumatismo dental.

Devido à freqüência de acidentes com os alunos nas escolas, por quedas, provocando traumatismos na região dento-bucal, como último questionamento aos professores na entrevista foi perguntado se o professor sabia socorrer um aluno com traumatismo dental, caso fosse chamado. 


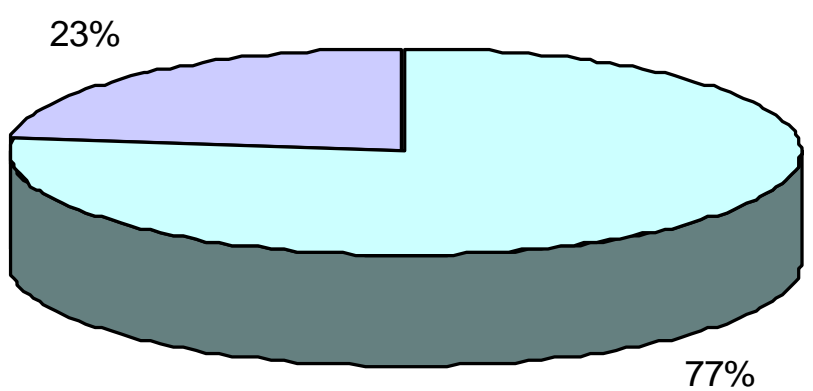

$\square$ Sabe

$\square$ Não sabe

Figura 13 - Socorrer traumatismo dental segundo professores pesquisados.

Verificou-se que $77 \%$ (236) dos professores responderam que sabiam socorrer, porém 23\% (71) responderam que não sabiam socorrer (figura 13). Aos que responderam que sabiam socorrer foi solicitado para explicar caso a criança sofresse avulsão de dente permanente nesse momento, como faria esse socorro. Nesse questionamento, os entrevistados citavam mais de uma resposta. Observou-se que $50,85 \%$ dos professores mencionaram levar ao dentista, $30,51 \%$ responderam guardar o dente, $11,86 \%$ citaram levar rápido ao dentista, 9,32\% levar ao Pronto Socorro, 8,90\% avisar aos pais, 6,36\% citaram levar à Faculdade, 5,93\% lembraram reimplantar o dente, $2,97 \%$ citaram chamar 0 SAMU, 2,12\% chamar a diretora e ainda 4,24\% deram respostas diferentes. Classificou-se como "outros" estas respostas: mandar fazer bochechos, colocar gaze, fazer parar - sangramento, levar para a diretora, pegar a criança e o dente e levar ao médico, de acordo com dados apresentados na tabela 22 . 
Tabela 22 - Tipos de socorro segundo professores pesquisados.

\begin{tabular}{lcc}
\hline Tipos de socorro & $\mathbf{n}$ & $\%$ \\
\hline Levar ao dentista & 120 & 50,85 \\
Guardar o dente & 72 & 30,51 \\
Levar rápido ao dentista & 28 & 11,86 \\
Levar pronto socorro & 22 & 9,32 \\
Avisar aos pais & 21 & 8,90 \\
Levar á faculdade & 15 & 6,36 \\
Reimplantar & 14 & 5,93 \\
Chamar SAMU & 7 & 2,97 \\
Chamar a diretora & 5 & 2,12 \\
Outros & 10 & 4,24 \\
\hline
\end{tabular}

Verificou-se ainda pelos dados de que maneira ele armazenaria o dente avulsionado ao transportá-lo até o atendimento, tendo como respostas diferentes líquidos tais como: $36 \%$ citaram colocar na água, 30\% colocar no leite, $13 \%$ no gelo, $12 \%$ colocar em soro fisiológico, e $9 \%$ mencionaram colocar na saliva, de acordo com o figura 14.

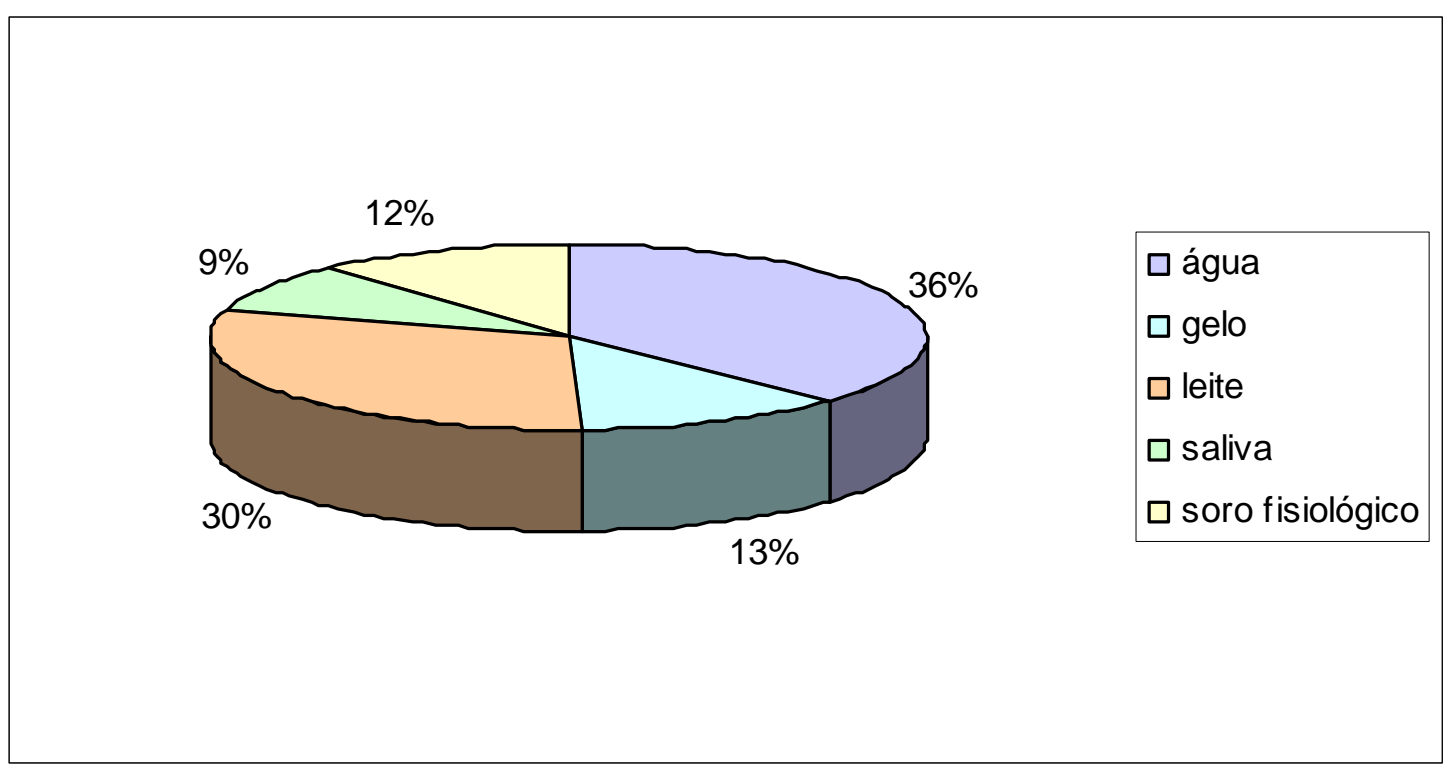

Figura 14 - Tipos de líquidos para armazenar dentes avulsionados segundo professores pesquisados. 


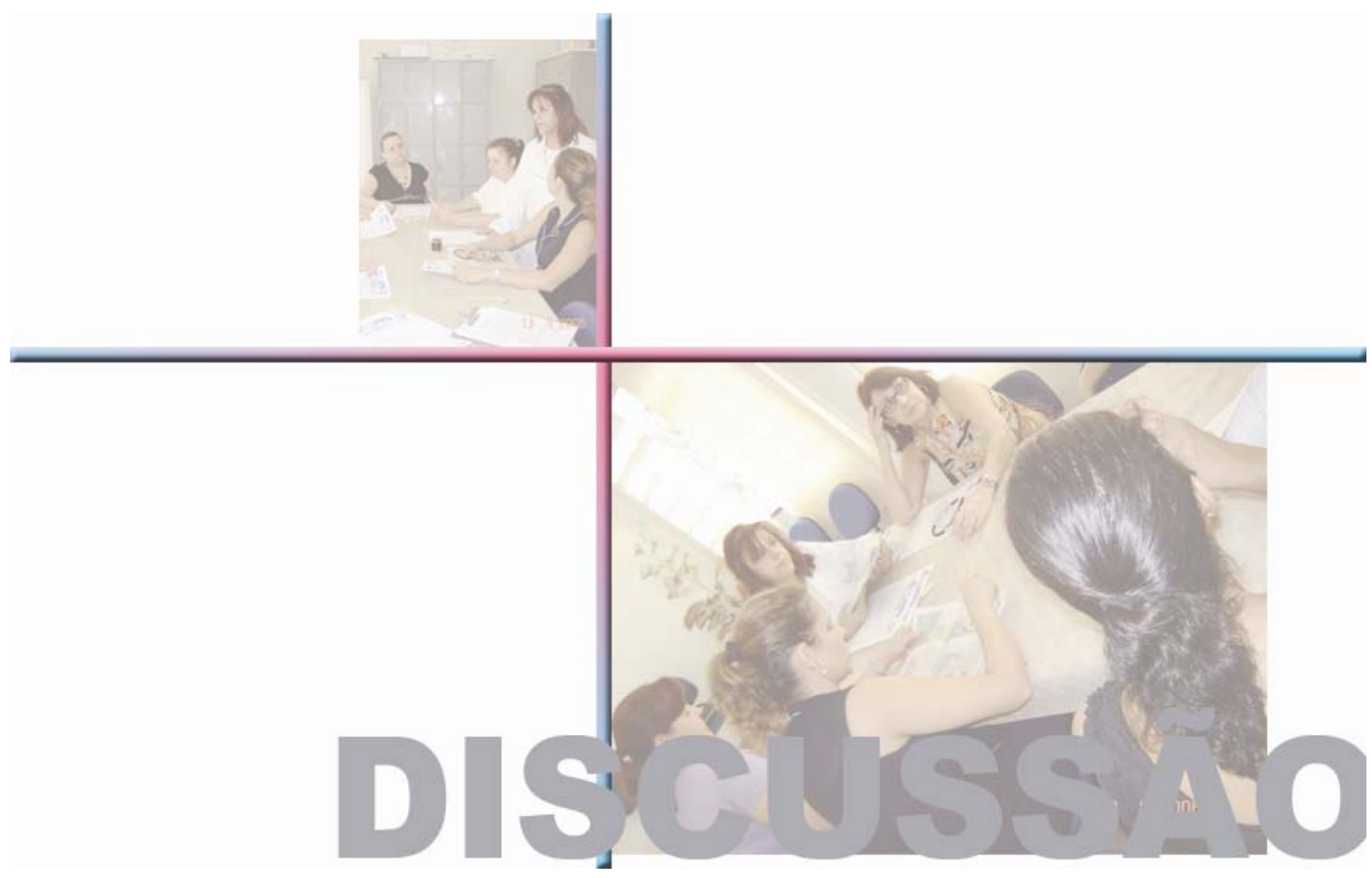

DISCUSSÃO 


\section{6 - DISCUSSÃO}

Estudos revelaram a importância de se estudar os educadores de escolas, conhecer suas atitudes e comportamentos referentes ao autocuidado com a saúde, seus conhecimentos, e se repassam as informações em saúde bucal nas aulas (FRAGA ${ }^{35}, 1999$; HILGERT $\left.{ }^{46}, 1999\right)$.

Para COSTA; FUSCELLA ${ }^{23}, 1999$, a partir do momento em que as mães tiveram que trabalhar fora de casa, para ajudar na complementação da renda familiar, muitos cuidados com a saúde e a educação foram delegados ao professor. Também é conhecido que os professores exercem fortes influências favoráveis na construção dos hábitos cotidianos de seus alunos, sendo eles, muitas vezes, forte exemplo em tudo que se refere à saúde geral e bucal, e tendo como responsabilidade ensinar e promover a educação em saúde (VASCONCELOS 110,2001$)$.

Em escolas de ensino fundamental, muitas crianças, principalmente das escolas públicas, só têm o professor como fonte de informações dos conceitos em saúde, o que reforça a necessidade de se conhecer a atuação em educação em saúde dos professores nessas escolas. Esses aspectos relevantes justificam que o educador precisa estar constantemente atualizado para desenvolver junto aos seus 
alunos práticas educativas cativantes e motivadoras, incentivando a participação crítica e consciente dos alunos. Isso permitiria que as crianças se sentissem bem e pudessem se espelhar nos hábitos dos seus professores $e$ os adquirissem levando-os também para suas famílias, tornandose agentes multiplicadores.

Ao se promover a saúde nas escolas, incentivar as esperanças e as aptidões das crianças e adolescentes, o potencial de criar um mundo melhor torna-se ilimitado, pois, se são saudáveis, segundo AQUILANTE6 ${ }^{6}$ 2003, podem aproveitar ao máximo toda a oportunidade de aprender, para o orgulho de seus familiares, seus professores e também engrandecimento da pátria.

Essas novas atitudes, se eficazes, poderão contribuir para a diminuição das doenças bucais da população, podendo essas crianças ter uma qualidade de vida e saúde melhor no futuro, e se tornarem cidadãos conscientes e multiplicadores dessas informações nas suas comunidades.

Para tanto, buscou-se conhecer a prática cotidiana dos professores relativas ao tema proposto na pesquisa, que serão discutidos em seguida. 


\subsection{Caracterização da amostra.}

Foram pesquisados os professores de escolas públicas estaduais e municipais, com o intuito de abranger o maior número possível das escolas públicas. As crianças dessas escolas, na maioria das vezes, têm seus professores como referenciais de informação em saúde de que eles têm acesso, podendo estes influírem de maneira marcante em suas formações (MOIMAZ et al. $\left.{ }^{69}, 1992\right)$. Segundo FREIRE ${ }^{37}$, 1999, a população atendida pela rede pública possivelmente representa grupo de baixa condição socioeconômica. O fato de pertencentes a famílias com baixo grau de instrução, resulta num diferencial não só econômico como também educacional e de estilo de vida com relação aos educandos da rede particular de ensino (MALTZ; SILVA $\left.{ }^{60}, 2001\right)$. Estudos de VASCONCELOS 110,2001 , ressaltaram que, quanto ao tipo de escolas, não há diferenças entre a abordagem em saúde bucal entre professores da rede municipal, estadual e particular de ensino.

Segundo informações do Instituto Brasileiro de Geografia e Estatística (IBGE), a cidade de Bauru possui 51 escolas estaduais, com efetivo de1500 professores, e 14 escolas municipais com 191 professores.

Como já foi citado na metodologia deste trabalho, a Delegacia de Ensino autorizou a pesquisa em 10 de suas 
escolas estaduais, fato esse fez com que a quantidade de escolas estaduais fosse proporcionalmente menor em relação às escolas municipais, nestas últimas foi permitida a realização da pesquisa em todas as 14 pela Secretaria Municipal de Educação.

A predominância do gênero feminino pela profissão do magistério foi confirmada nesta pesquisa. Grande parte das escolas infantis e de ensino fundamental apresentam essa predominância, principalmente nas séries iniciais. Presume-se que possa haver uma ligação com o instinto maternal presente nas mulheres, e isso facilite e favoreça essa tendência na profissão, pois no ensino primário-infantil as crianças se apresentam muito carentes de atenção.

Pesquisas de SGAN-COHEN et al. ${ }^{95}, 1999$ entre professores de escolas na Arábia em 1999, encontraram $51,5 \%$ do gênero feminino. Para os autores, as professoras mulheres na Arábia demonstravam nível mais positivo de conhecimentos e atitudes em saúde bucal do que seus colegas homens, isso decorrendo do fato de que a maioria de professores de ensino fundamental, tanto na Arábia quanto em outras populações, é constituída por mulheres.

Para DELCOR et al. ${ }^{27}, 2004$, a predominância da mulher na profissão de educar sempre aparece na variação de 75 a $85,6 \%$, tendo sido na presente pesquisa, encontrado um valor maior do que essa citação desse autor $(97,72 \%)$. Os 
mesmos afirmaram ainda que com a expansão do setor educacional, no Brasil, a partir da segunda metade do século $X X$, foi preciso a incorporação de muitos trabalhadores para o ensino. A docência e a enfermagem foram consideradas, na época, atividades próprias das mulheres por envolver os cuidados dos outros. As mulheres foram, então, chamadas para ocupar os cargos de educadora, considerando-se o trabalho na escola como uma continuação de tarefas no âmbito doméstico, e aparecendo uma forte analogia com a imagem da mãe à educadora, principalmente nos primeiros anos de escolaridade.

O magistério infantil, de acordo com DELCOR et al. ${ }^{27}$, 2004, por oferecer baixos salários no Brasil, é muito procurado por mulheres que se ocupam dessa profissão para complementar a renda familiar, pois os homens não mostram interesse em procurar lecionar no magistério infantil.

Para CARVALHO ${ }^{21}, 1995$, na realidade brasileira o magistério está incluído em uma categoria profissional do gênero "feminino", sendo, portanto, desprestigiado na escala profissional e isso pode fazer com que a "Realização Pessoal" com os resultados do trabalho, ou o "status" e reconhecimento oriundos do mesmo sejam baixos ou inexistentes entre os profissionais do gênero masculino, gerando desinteresse completo pelos mesmos. 
Nos resultados sobre a faixa etária, SILVA ${ }^{98}, 2002$, encontrou que $74 \%$ dos professores estudados situavam-se entre 31 a 50 anos de idade. Na presente pesquisa a concentração foi $63,52 \%$ dos professores na faixa etária de 30 a 49 anos de idade.

Com menos de 30 anos de idade, SILVA ${ }^{98}, 2002$, encontrou $15 \%$ dos professores pesquisados, sendo que neste presente trabalho observou-se $13,36 \%$ da amostra nesta faixa etária 19 a 29 anos.

Com mais de 60 anos, SILVA ${ }^{98}, 2002$, encontrou $1 \%$ dos professores entrevistados e, neste trabalho, encontrou-se também menor concentração, sendo 3,26\%.

A faixa etária de professores foi também estudada por GUIMARÃES ${ }^{43}, 2005$, que encontrou $50 \%$ dos docentes com mais de 40 anos, seguindo-se 14,3\% na faixa etária de 31-35 anos e $14,3 \% 36-40$ anos.

A importância de conhecer o tempo de serviço dos professores favorece à observação da motivação, empenho e possibilidade de se implementar novos e atualizados conceitos em saúde a esses professores mesmo sendo recém-formados. Não só o estudo do tempo de dedicação profissional influencia no interesse a novos conhecimentos e técnicas como a importância da formação dos novos educadores. 
De acordo com SGAN-COHEN ${ }^{95}, 1999$, os professores iniciando o magistério têm maior disposição e entusiasmo para o ensino, pois se encontram mais motivados e podem ser encorajados a trabalhar com ensinamentos em saúde para seus alunos e receber esses treinamentos nessa fase.

$\mathrm{Na}$ presente pesquisa (tabela 5), observou-se que $25,41 \%$ estavam entre 1 a 10 anos de trabalho profissional e $54,52 \%$ entre 11 a 20 anos. Ao englobar essas duas faixas de tempos de serviços, verifica-se que 79,93\% dos entrevistados se encontravam com menos de 20 anos de tempo de serviço como docentes.

Os profissionais com mais de 20 anos de profissão segundo CARVALHO ${ }^{21}, 1995$, já conseguiram suplantar o "stress" inicial e continuam na profissão por terem adquirido habilidades e criado mecanismos de adaptação, superando as dificuldades. Pressupõe-se que por vezes se mostram perdendo o entusiasmo, e podem estar mais acomodados com as exigências e resultados que possam obter na profissão. Os dados neste questionamento fortalecem o pensamento de se investir no tema saúde em geral na formação dos novos professores, como também oferecer capacitação aos que estão na ativa com menos de 20 anos de trabalho.

Um estudo sobre o perfil do professor no Brasil, com bases em estudos (2006) de Estatística dos professores no Brasil do Instituto Nacional de Estudos e Pesquisas 
Educacionais, do Ministério de Educação e Cultura, INEP$M C^{8}, 2006$, constatou que o professor que atua na educação infantil tem como média salarial $R \$ 423,00$ no país. Os docentes que lecionam em turmas de $1^{\mathrm{a}}$ a $4^{\mathrm{a}}$ séries se enquadram numa remuneração de $R \$ 462,00$ e os de $5^{\mathrm{a}}$ a $8^{\mathrm{a}}$ séries $R \$ 600,00$. Já um professor que atua no nível médio percebe salário de em média, $R \$ 866,00$. As diferenças salariais, segundo esse estudo, são marcantes entre os professores nas diversas regiões do Brasil, sendo que na região sudeste o professor ganha em média duas vezes mais que seu colega no Nordeste. (INEP-MEC $\left.{ }^{8}, 2006\right)$

É do conhecimento de todos que um dos grandes motivos de insatisfação dos professores de ensino fundamental é a desvalorização profissional, reflexo dos baixos salários e, conseqüentemente, perda do prestígio social. Uma pesquisa de DELCOR et al. ${ }^{27}, 2004$, em Vitória da Conquista no estado da Bahia, observou que muitos professores trabalhavam em outras escolas ou em outra atividade remunerada por necessidade de complementar uma renda familiar insuficiente, portanto, tinham uma carga horária elevada, e 56\% tinham uma renda mensal inferior a quatro salários mínimos da época.

No presente estudo (tabela 6), foi encontrado que $60,26 \%$ dos professores, com renda familiar entre um a três mil reais, próximo ao que encontrou o autor acima referido. 
Observou-se, ainda, que um grupo de 69 professores, ou seja, $22,48 \%$ citou ter como renda familiar entre 400 reais a um mil reais, às vezes como única renda citado por alguns.

Estudos de CARVALHO ${ }^{21}, 1995$, sobre a remuneração dos professores referiu que há muito tempo essa remuneração deixou de ser condigna, pois o achatamento salarial do funcionalismo público, em geral, vem atingindo níveis muito baixos e modificando sobremaneira a vida do professor e, conseqüentemente, seu "status" social. Afirmou que o professor não está destacado entre os ricos e ao se ver distanciando de profissões que no passado eram paralelas, em termos de prestigio e salário, e submetido a um empobrecimento seletivo crescente, passa a ter maior identificação com os demais trabalhadores que, muitas vezes, nem estudos têm. Por outro lado, ROOSI ${ }^{90}, 2001$, referiu positivamente sobre os professores de escolas públicas, dizendo que mesmo com salários cada vez mais baixos, esses profissionais passam a ser apreciados como criaturas flexíveis, que agüentam ano após ano, trabalhando duro, e sempre mantendo sua capacidade de mudar, de adaptar-se às circunstâncias, por isso são admiráveis.

A respeito do nível acadêmico dos professores, resultados de SILVA ${ }^{98}, 2002$, em seus estudos mostrou $64 \%$ dos professores com nível superior. DELCOR et al. ${ }^{27}, 2004$, encontrou $71,9 \%$, já GUIMARÃES ${ }^{43}, 2005$, encontrou $50 \%$ com 
curso superior. Na presente pesquisa, os valores encontrados foram 63,84\% de professores com nível superior, resultado semelhante aos que encontrou DELCOR et al. ${ }^{27}, 2004$. Se considerarmos as porcentagens dos que têm curso superior $(63,84 \%)$, mais os que têm especialização $(20,85 \%)$ e mestrado $(0,98 \%)$, os professores perfazem $85,67 \%$, portanto mostrando nível de escolaridade bem qualificado, pressupondo-se que, por isso, estejam bem preparados.

\section{A LEI dE DIRETRIZES E BASES DA EDUCAÇÃO ${ }^{10}$.} 9394-96, aprovada em 1996, passou a exigir escolaridade de nível superior para todos os níveis de ensino, e essa exigência, segundo DELCOR et $\mathrm{al}^{27}, 2004$, seria a responsável pelo aumento no nível de qualificação dos docentes.

Com referência à formação acadêmica dos professores, VASCONCELOS et al. ${ }^{110}, 2001$, encontrou a escolaridade em professores de ensino fundamental de $1^{\circ}$ grau em escolas públicas de Belo Horizonte com níveis bem elevados, sendo $4 \%$ doutores, $40 \%$ com grau de mestres, $32 \%$ especialistas e $24 \%$ graduandos. Porém, ele citou que mesmo com graus de escolaridade elevados, os professores repassavam para as crianças informações em saúde e higiene bucal que haviam aprendido em suas escolas de ensino fundamental. Com relação à escolaridade, GUIMARÃES et al. $^{43}, 2006$, encontrou $50 \%$ dos professores pesquisados 
tinham apenas o magistério, bem mais do que os resultados na presente pesquisa, onde $14,33 \%$ responderam ter feito somente o magistério. A escolaridade dos professores foi estudada também por CARVALHO ${ }^{21}, 1995$, referindo que, com relação a essa situação do professor do ensino fundamental com título de mestre, pode se pressupor que eles não se sentem realizados por estarem em um nível de formação profissional mais elevado que o exigido para o exercício da profissão. Eles não têm na carreira outro posto a aspirar talvez porque as condições de trabalho não permitem utilizar tudo o que sabem. A única vantagem dos profissionais, segundo CARVALHO ${ }^{21}, 1995$, são os $10 \%$ de aumento salarial em relação aos que não tem. Com vistas à aspiração por situações melhores, os níveis de pós-graduação para professores de ensino fundamental possibilitam vislumbrar não só melhores salários, mas uma transposição sóciopolítico-cultural, pela possibilidade de seu ingresso em outros níveis do ensino, como o segundo grau ou o superior onde há uma melhor qualificação e valorização e prestígio em relação ao magistério.

\subsection{Comportamentos e atitudes em saúde bucal.}

Para conhecer o comportamento e atitudes do professor, pesquisaram-se os hábitos referentes ao seu autocuidado em higiene bucal. Estes puderam ser observados 
através de indagações sobre trocar de escovas regularmente, tempo de demora para trocar de escovas de dente, quantidade de escovações diárias, levar escovas de dente para o trabalho, características das escovas dentais. Verificou-se a importância que esses profissionais davam à sua própria saúde e na rotina diária dos seus ensinamentos aos alunos. As respostas de $77,20 \%$ professores em trocar suas escovas de dentes no tempo entre 1 a 3 meses (tabela 8) se mostraram adequadas de acordo com os autores estudados, PANZERI ${ }^{74}$, 1993, TUMENAS ${ }^{105}$, 1999, BARROS ${ }^{12}, 2001$. Esse tempo de troca, segundo os autores, vai depender da intensidade e freqüência diária como fazem as escovações dentárias, e também do desgaste das cerdas das escovas fazendo com que percam sua efetividade na escovação. TUMENAS ${ }^{105}$, 1999, citou que uma escova com cerdas extramacias ou macias costumam durar no máximo 30 dias, e, após esse período, as cerdas começam a se abrir e a perder sua efetividade. Estudos de BARROS ${ }^{12}, 2001$, referiram que a escova deve ser substituída a cada 3 meses, porém 0 desgaste varia individualmente em função da funcionalidade das cerdas. Portanto, algumas pessoas trocam as escovas com menos de 3 meses devido ao desgaste das cerdas.

Quando perguntados se levavam a escova de dente para o trabalho, $48,53 \%$ dos docentes responderam negativamente (tabela 9). Alguns procuravam explicar que, 
por trabalhar por meio período na escola, faziam suas refeições e escovação dos dentes nas suas casas. Outras vezes respondiam que esqueciam de levar, e alguns respondiam que durante o trabalho não tinham tempo. Houve até alguma citação de usar o chicletes para limpeza dos dentes porque, após os intervalos, não tinham tempo para higienizar os dentes durante o horário de trabalho na escola. Esse comportamento sugere que essas atitudes não refletem exemplo favorável ao ensinamento em saúde bucal.

A importância de levar a escova de dentes para o trabalho está na oportunidade de o professor influenciar seus alunos, quando ele apresenta comportamentos favoráveis utilizando as medidas preventivas mais comuns para evitar as doenças bucais, e através dessa atitude gerar ensinamentos de saúde bucal na sua vivência com a criança na escola.

$\mathrm{Na}$ freqüência de escovações diárias, verificou-se que a maioria (88\%) mencionou que fazia suas escovações na freqüência entre 3 a 5 vezes por dia (figura 2). Os 28\% de respostas tendo 3 como freqüência de escovações podem ser aceitas como correta segundo autores pesquisados. Embora possam conter também influências de informações da mídia que sempre menciona escovar os dentes 3 vezes ao dia. Dados semelhantes encontrou SANTOS et al. ${ }^{93}, 2003$ quando pesquisou professores em Araraquara. 
Sobre freqüência diárias, o trabalho de BARROS et al. ${ }^{12}$, 2001, descreveu que três escovações diárias são consideradas satisfatórias. A escovação mais criteriosa para os autores deve ser antes de dormir, escovar sem pressa, minuciosamente tocando todas as superfícies dentárias e não esquecer de higienizar a língua também. Para TUMENAS ${ }^{105}$, 1999, a quantidade de vezes por dia que é necessário escovar os dentes depende do risco do paciente à cárie ou à doença periodontal. E aos pacientes considerados "normais" sem a doença, ainda se prescreve que se façam três escovações ao dia: pela manhã, após o almoço, e após o jantar ou antes de dormir. Deve-se saber, contudo, que a higienizacão mais importante é aquela realizada à noite.

As características de escovas dentais foram também pesquisadas por SANTOS et al. ${ }^{93}, 2006$, quando avaliaram professores. Os resultados encontrados pelo autor demonstraram que $68,5 \%$ dos professores citaram escovas de cerdas macias como adequadas, $5,4 \%$ citaram cabeça pequena, 3,3\% cabeça arredondada. Esta presente pesquisa registrou valores superiores onde a maioria, $75 \%$ dos entrevistados, preferiram escovas macias, $23 \%$ escovas de cabeça média, $21 \%$ de cabeça pequena (tabela 10). A resposta de preferir escovas macias é aceitável, pois são mais indicadas por não causar ferimentos nas gengivas e demasiado desgaste no esmalte dos dentes. Por outro lado, é 
o tipo de escova mais indicado pelos dentistas e explorado pela mídia, o que possibilita essa resposta conter influências dessas fontes. Segundo BARROS et al. ${ }^{12}, 2001$, as características das escovas mais adequadas por facilitar melhor os procedimentos de higiene bucal são: ser de cabeça pequena, multitufulada, cerdas macias e arredondadas, para atingir as regiões na boca de difícil acesso.

\subsection{Conhecimentos em saúde bucal.}

A educação e a informação sobre os cuidados com a saúde bucal têm sido ressaltadas por diversos pesquisadores (PINTO ${ }^{82}$, 1997; PAULETO ${ }^{75}$, 2004; MEDEIROS $\left.{ }^{64}, 2004\right)$. Embora as informações sejam disponíveis nas grandes mídias, não chega a toda população da mesma forma, e dificilmente é aprendida de modo a produzir conhecimento em relação aos cuidados com a saúde (PAULETO $\left.{ }^{75}, 2004\right)$. Na educação em saúde do escolar o educador pode envolver a criança para construir novos conhecimentos, provocar mudanças de atitudes, hábitos e cuidados, principalmente por ser um exemplo dessas práticas. No presente trabalho, os dados se revelaram positivos em relação aos professores levarem ensinamentos aos alunos sobre modos corretos de fazer higiene bucal, pois verificou-se que $72,96 \%$ dos entrevistados (tabela13), ensinavam os alunos como escovar 
os dentes e $92,51 \%$ afirmaram que também falavam da importância da saúde bucal na aula (tabela 12). Por outro lado, 6,8\% não abordavam saúde bucal na aula e 26,71\% não orientavam os alunos como escovar os dentes.

As respostas a esses questionamentos, em que a maioria respondeu positivamente (tabelas 11, 12 e 13), sugerem comportamentos e atitudes de interesse desses professores em repassar seus conhecimentos, aproveitando oportunidades para essa prática educativa, o que não podemos pensar do restante com respostas negativas.

Quando estes professores citavam que não orientavam higiene bucal, nem abordavam importância de saúde bucal, procuravam justificar que não desenvolviam esses temas de saúde com os alunos porque não fazia parte dos conteúdos integrantes da grade curricular, ou por falta de conhecimento, ou não eram especializados, citavam falta de material apropriado sobre o assunto e pouco tempo disponível.

Dos autores que estudaram esse assunto com professores, MEDEIROS ${ }^{64}$, 2004, encontrou entre professores da $1^{\mathrm{a}}$ à $4^{\mathrm{a}}$ série de ensino fundamental da cidade de João Pessoa dados bem diferentes onde $64 \%$ dos professores nunca abordaram conteúdos referentes à saúde geral ou bucal na sala de aula, e $8 \%$ faziam ocasionalmente, já, pesquisas de POMARICO 84,2000 , em professores de $1^{\circ}$ Grau de escolas 
públicas do Rio de Janeiro, evidenciaram que $62,7 \%$ dos professores ensinavam normalmente a seus alunos o modo de escovar corretamente os dentes. É muito importante destacar aqui que a escola tem um papel relevante na promoção da saúde, através da educação em saúde, alcançando hábitos e estimulando práticas que levem à manutenção da integridade dos tecidos bucais (PAULETO $\left.{ }^{75}, 2004\right)$.

Mesmo quando o educador não possui nenhum tipo de recurso material para apoiar a ação educativa, ele pode obter bom retorno por parte do educando, se possuir compromisso de fato na melhoria de vida do indivíduo e com uma sociedade mais justa, e procurar se esforçar em buscar antecipadamente esse material educativo sobre qualquer assunto que deva ser levado ao educando (LOUREIRO $\left.{ }^{56}, 1996\right)$.

A origem das informações em saúde bucal dos professores foi investigada, nesta pesquisa, conforme dados apresentados na tabela15, o que demonstra que a metade (50\%) referiu que recebeu as informações de seus dentistas, seguidos respectivamente de escola (40\%), mídia (27\%) (tv, jornais, rádios e revistas, propagandas, panfletos), família (23\%), curso (17\%), livros (14\%) e outros (15\%). A opção "outros" remete ao conhecimento empírico tal como dia-a-dia, vida cotidiana, como também citações na área da saúde como agente de saúde e auxiliar de dentista. 
Diversos autores que realizaram pesquisas semelhantes relataram também variadas fontes como origem das informações sobre saúde bucal. Para VASCONCELOS ${ }^{110}$, 2001, que pesquisou a origem das informações em professores de escola pública de Belo Horizonte, $56 \%$ dos professores responderam que nunca tiveram estudos relacionados com saúde bucal na sua formação. FERREIRA ${ }^{31}$, 2005, pesquisou alunos concluindo pedagogia (João Pessoa) encontrando como origem das informações palestras sobre saúde bucal. Já MEDEIROS 64,2004 , (professores de escolas públicas de João Pessoa) não só encontrou palestras como também leitura sobre o assunto. Tanto SGAN-COHEN ${ }^{95}, 1999$, que pesquisou professores na Arábia Saudita, quanto SANTOS; RODRIGUES; GARCIA ${ }^{93}$, 2003, que pesquisaram professores em Araraquara, encontraram nos seus resultados sobre a origem das informações o cirurgião-dentista, a família e a mídia. PETERSEN; ESHENG ${ }^{79}, 1998$, estudando a origem de informações de professores na China encontraram resultados bem diferentes, sendo eles por ordem: televisão, depois livros, rádio, jornais, revistas, e por último os dentistas. Outro trabalho de PETERSEN; ESHENG ${ }^{79}, 1998$, avaliando professores em Zanzibar, sobre origens das informações em saúde bucal, também relatou dados diferentes desta pesquisa sendo: livros, rádio e depois dentista. Para 
LANG ${ }^{51}, 1989$, as respostas foram clínicas e consultórios odontológicos.

Complementando esses dados sobre as formas de informações em saúde bucal, investigou-se se o professor havia realizado ou não algum treinamento sobre o assunto. Uma grande quantidade (64\%) de professores responderam que nunca receberam treinamento em saúde bucal (figura 3). VELLOZO 111 , 2005, encontrou dados diferentes em sua pesquisa com professores de escola públicas do Rio de Janeiro, onde $88 \%$ tinham recebido treinamento com orientações em saúde bucal. Com relação aos $64 \%$ de professores da presente pesquisa, que revelaram nunca haver recebido treinamento, estes demonstraram estar em desvantagem de conhecimentos em relação ao restante do grupo (36\%), que recebeu treinamentos vindos de dentistas de escola, de cursos e palestras e de dentistas particulares, conforme dados da tabela 16. Essas fontes de informações científicas podem ser consideradas fidedignas. Quando analisamos esses dados relacionando-os com os resultados da origem das informações, que foi o questionamento anterior, verificamos que muitos professores (27\%) tinham recebido informações da mídia. É conhecido por todos que a mídia fornece muitos conhecimentos fragmentados, levando a confusões de conceitos. Juntando isso ao fato de que nesta questão a maioria dos professores (64\%) relata que não 
recebeu nenhum treinamento em saúde bucal, pode-se pressupor que os conhecimentos em saúde bucal desses professores podem ser inconsistentes, necessitando de treinamentos, atualizações e reavaliações.

\subsection{Conceituações etiológicas das doenças bucais.}

Com relação às doenças bucais, inúmeros trabalhos na literatura afirmam conclusivamente que a placa bacteriana é fator etiológico tanto para a cárie dentária como para a doença periodontal (PINTO $\left.{ }^{82}, 1997\right)$. Essas doenças bucais são comuns na população brasileira, tanto em adultos como em crianças. Para poder ensinar sobre elas, é preciso conhecer os conceitos da formação inicial dessas doenças, e a que fatores estão associados, e saber como evitá-las. Daí surge a grande importância de se fazer e orientar para uma boa escovação dos dentes diariamente aliado ao uso do fio dental, para remover a placa bacteriana que se forma sobre e entre os dentes. A cárie dentária embora esteja diminuindo não está erradicada da população e continua sendo motivo de preocupação, principalmente em crianças de escolas públicas (FREIRE ${ }^{36}$, 2001). Nas escolas existem crianças de classe menos favorecida economicamente, os quais não têm acesso a informações nem a serviços de saúde. Esta é, então, uma 
grande oportunidade para o professor atuar como um educador em saúde bucal, sendo necessário que ele esteja bem convicto dessas noções para informar adequadamente às crianças nas escolas. Apesar de todos os problemas, carências e desacertos da educação brasileira, é somente pela aprendizagem formal, obtida na escola, que muitas crianças terão acesso a algum tipo de conteúdo científico, e os professores devem estar bem preparados, ter acesso aos conceitos científicos e repassá-los em práticas para as crianças de maneira eficiente, convicta, adequada, alegre, motivadora. (MELO; FREIRE ; BASTOS $\left.{ }^{65}, 2005\right)$.

Com respeito ao questionamento para o professor citar as razões de se manter uma boa higiene bucal, esperava-se que ao responder eles lembrassem os aspectos etiológicos relacionados com as duas principais doenças bucais cárie e doença periodontal tais como: remover placas bacterianas, prevenir cáries, prevenir doenças de gengivas, prevenir doenças periodontais, visto que palestras realizadas em escolas referem-se ao assunto. No entanto, observando a tabela 17 notamos que a maioria dos professores mencionou como razão primeira a saúde, 56,35\%, seguida de estética $24,76 \%$, bom hálito 23,13\%, prevenção de doenças 14,33\%, prevenção à cáries $13,68 \%$, conservar os dentes $13,03 \%$, e bem depois aparece prevenção a doença periodontal 4,2\%. A dificuldade dos professores em citar a prevenção das duas 
mais comuns doenças dentárias, pressume-se que se deva ao costume que os professores têm de facilitar explicações para as crianças, não usando os termos técnicos pois não é do seu conhecimento, e usar muitas explicações diminutivas e figuradas, orientando a fazerem a higiene bucal apenas pela estética, aparência. Notou-se que a saúde, sendo a resposta mais citada, e primeira opção de imediato quando respondiam, sugeriu um conhecimento geral, possivelmente intuitivo. Nas respostas, prevenção às doenças, continham citações de outras doenças incluídas tais como: doenças cardíacas, infecções respiratórias, câncer bucal, doenças em geral, também sugerindo o conhecimento de noções de doenças que podem surgir de início na cavidade bucal.

Pesquisas de $\mathrm{LANG}^{51}, 1989$, com professores de zona urbana e rural, em Michigan, investigaram o conhecimento dos professores e questionaram sobre as razões de se manter boa higiene bucal, e relacionaram dados bem diferentes dos mencionados nesta pesquisa, citados acima, sendo $65 \%$ dos professores citaram a prevenção de cárie dentária, em seguida $52 \%$ prevenção de doenças de gengivas, mas também incluíram outras razões empíricas como diminuição dos custos dos tratamentos e ser um exemplo para as crianças.

É importante reforçar esses conhecimentos etiológicos para os professores, tanto da cárie como da doença de gengiva ou periodontal, pois a maior parte deles 
$(97,72 \%)$ relatou no início da pesquisa, que sempre falavam sobre saúde bucal para os alunos.

Os autores FREIRE ${ }^{36}, 2002$, no interior de Goiás, e MALTZ; SILVA 60 , 2001, em Porto Alegre-RS, comprovaram essas doenças em crianças de escolas públicas de ensino fundamental de classes sociais menos favorecidas. Esses escolares apresentavam maior prevalência da doença cárie e de sangramento gengival, possuíam poucas informações sobre saúde, sobre cuidados de higiene bucal, e não conseguiam atendimentos em serviços de saúde.

Ao questionar-se os professores sobre conhecer a doença periodontal e como preveni-la, verificou-se através dos dados que estão apresentados nos figuras 4,5 e 6, que essa doença não é bem conhecida entre os professores, e dos $54 \%$ que responderam que sabiam como evitar somente $5 \%$ citou remover a placa dental (figura 6). As respostas "ter boa higiene bucal" e "freqüentar o dentista" podem conter influência da mídia, que ressaltam sempre a boa higiene e freqüentar o dentista, condicionando a fixação desses conceitos na população.

Os problemas periodontais segundo UNFER; SALIBA ${ }^{107}$, 2000, não apresentam uma evolução contínua da destruição dos tecidos de suporte do dente. Com o tempo, acontecem períodos de atividade e inatividade da doença no adulto, e só em algumas pessoas ou sítios a afecção evolui 
para perda dentária. Esse fator pode influenciar no desinteresse popular pela doença, e pode ser o motivo pelo desinteresse dos professores, neste estudo, pois grande quantidade desconhecia a doença e sua prevenção. Dos que responderam que sabiam prevenir, demonstraram fraca importância em remover a placa bacteriana, pois apenas 5\% a citaram.

As respostas ao questionamento sobre os conceitos etiológicos das doenças bucais pressupõem-se incompletas, visto que não foi mencionado objetivamente a remoção da placa bacteriana causadora de doenças bucais como principal motivo para se fazer uma boa higiene bucal. Outro fator a destacar é que quando os entrevistados respondiam sobre os assuntos específicos davam sempre uma entonação de pergunta na voz quando respondiam, demonstrando assim insegurança do assunto.

Em relação à doença periodontal, além de nem todos professores conhecerem a doença e sua prevenção, muitos faziam menção confundindo-a com ortodontia. Esses termos técnicos geravam insegurança nas respostas, o que leva à necessidade de maior divulgação dos conceitos da doença para os professores e para a população.

6. 5. Conhecimento das medidas preventivas em saúde bucal. 
O conhecimento sobre flúor é específico de educação em saúde bucal. Embora haja dificuldade e resistência, por parte dos professores, em falar sobre esse elemento para os alunos, sua utilização adequada e cuidadosa pode ser explicada aos escolares pelos professores. No aspecto de prevenção de cárie dentária, o uso de fluoretos é muito importante, sendo a forma mais utilizada para prevenção à cárie em saúde pública através da fluoretação das águas de abastecimento; e de forma individual, o uso de dentifrícios fluoretados nas escovações dos dentes deve ser incentivado e ensinado, lembrando que em crianças acima de sete anos a quantidade de dentifrício não deve ultrapassar o tamanho de um grão de feijão. Outro tipo de prevenção à cárie é através da redução do consumo do açúcar e do controle da placa bacteriana, os quais devem ser desenvolvidos também com os familiares dos escolares (HILGERT $\left.{ }^{46}, 2001\right)$.

Tanto a utilização correta da quantidade de dentifrício fluoretado como uso racional do flúor, para não ocorrer riscos de fluorose nas crianças, como os ensinamentos das funções dos fluoretos e presença de flúor na água de abastecimento público, são medidas preventivas que devem ser controladas pelos órgãos públicos, e são assuntos que devem ser adicionados ao conhecimentos dos professores. Portanto, é importante informar aos alunos informar aos alunos que a água de abastecimento público 
fornecida à população de Bauru é fluoretada e que a quantidade correta de flúor na água é controlada pelo Departamento de Água e Esgotos-DAE. Ensinar que os seus benefícios na prevenção à doença cárie dentária foram muito importantes para a população, principalmente quando associados a outros vindos dos dentifrícios fluoretados. Esses fatores, ligados a outras medidas como uso tópico de flúor e práticas preventivas, contribuíram em muito para a diminuição dos índices altos da cárie dentária no município, (BASTOS et al. $\left.{ }^{11}, 2002\right)$.

Os benefícios dos fluoretos, transformaram o cenário da cárie dentária no mundo, no Brasil, e em Bauru também. Surgiu daí a importância de fortalecer cada vez mais a necessidade de se trabalhar com as crianças na fase escolar a prevenção das doenças bucais.

CAMPOS E GARCIA ${ }^{19}, 2004$, pesquisaram professores de escolas públicas de Araraquara, para investigar as funções do flúor, e encontraram que $73,7 \%$ dos professores responderam ação preventiva à cárie, e 36,8\% responderam que o flúor atua na proteção do esmalte dos dentes. LANG ${ }^{51}$, em 1989, em Michigan, questionou grupos de professores de ensino fundamental sobre efeito do flúor nos dentes, observando que os mesmos possuíam corretas informações sobre habilidade do flúor de melhorar a resistência dos dentes. Já PETERSEN ${ }^{78}$, 1998, encontrou baixos 
conhecimentos dos professores de Zanzibar sobre o flúor, e, na China, PETERSEN ${ }^{78}$, 1998, encontrou que 50\% dos professores estavam conscientes dos efeitos positivos do flúor. Estudos de ALVES et al. ${ }^{4}$, 2001, que pesquisaram professores de ensino fundamental de escolas de Natal-RN, encontraram resultados positivos onde $97,36 \%$ dos professores referiram a função do flúor para prevenção da cárie, o que refletiu pensar que esses professores estavam informado sobre o assunto.

Sobre as funções do flúor, na presente pesquisa, encontrou-se que $52,30 \%$ citaram prevenção à cárie, em seguida $34,34 \%$ citaram proteção, e 16,61\% citaram fortalecer os dentes, respostas estas mais adequadas para a funções do flúor (tabela 18). Isso pode refletir que esse grupo de professores conhece os efeitos preventivos do flúor. Nas citações de funções do flúor, as respostas como hálito puro, dentes brancos, higiene dos dentes e evidenciar placas podem também conter influências da mídia. Haja vista que muitas respostas pesquisadas anteriormente sobre origens das informações em saúde bucal vinham dessa fonte de informações. Muitas propagandas vistas diariamente recomendam o uso de colutórios e dentifrícios, em geral, para obter esses referenciais citados (hálito puro, dentes brancos, para evidenciar placas, e proteger os dentes), o que pode 
gerar uma confusão no conhecimento da população e dos professores.

Quando FERREIRA ${ }^{30}$, 2006, entrevistou estudantes de pedagogia de uma Universidade Paulista (futuros professores) sobre conhecimento das funções preventivas do flúor, as respostas foram positivas nesse aspecto. Porém quando questionou sobre local de acesso, eles associaram principalmente à ida ao dentista e não com a água de abastecimento ou ao creme dental fluoretado. Da mesma forma outra pesquisa de acesso ao flúor realizada por UNFER; SALIBA ${ }^{107}, 2000$, demonstrou que a maioria dos professores pesquisados respondeu que o flúor é encontrado no dentista.

Verificou-se que, mesmo que muitos tenham respondido satisfatoriamente (tabela 20) sobre o acesso ao flúor na água de abastecimento (44,89\%) e nos cremes dentais $(39,42 \%)$, uma parte dos pesquisados $(10,22 \%)$ ainda desconhecia ou não lembrou esse acesso ao flúor, portanto necessitando reforçar e reaplicar esses conhecimentos.

Destacou-se, ainda, nos dados da tabela 20, que parte da população estudada respondeu encontrar flúor nas farmácias $(14,60 \%)$ e nos dentistas 30,29\% (consultórios, clinicas, o dentista prepara, colutórios). O que se pode pressupor, de acordo com os estudos de UNFER; SALIBA ${ }^{107}$, 2000, é que essas respostas indicam que os professores reconhecem no flúor um medicamento, principalmente quando 
citaram farmácias, e que o dentista prepara o flúor. O fato de mencionar escolas como local de acesso ao flúor reflete, segundo o mesmo autor, o conhecimento da existência dos programas de bochechos com soluções fluoretadas que eram implantadas pelo município nas escolas. Em "outros" citavam as lojas dentais especializadas, lojas de cosméticos.

A importância de utilização do flúor usado em prevenção de cáries em crianças e adultos é vista na atualidade, não só como agente preventivo mas sobretudo terapêutico. Isso reforça a importância da sua utilização, visto que a presença do flúor no meio bucal aumenta o ganho e diminui a perda mineral dos dentes em exposições diárias em baixo pH. Por isso podem ser usados para tratamento de lesões incipientes de cárie dentária. Essas evidências ressaltam a importância da divulgação entre a população desses benefícios do flúor como medidas preventivas e terapêuticas (ARNEBERG; SAMPAIO ${ }^{7}, 2000$ ).

Com relação ao uso e funções do fio dental, foi questionada a investigação das noções dos conceitos dos professores quanto à prevenção da formação de placa bacteriana entre os dentes. Por ser um procedimento preventivo de doenças bucais bem conhecido pela população, espera-se que seja incentivado seu uso entre os escolares.

A placa bacteriana não sendo removida por meio de completa higiene bucal, durante a escovação diária e uso do 
fio dental, pode caminhar para desenvolvimento da cárie dentária nas regiões interproximais dos dentes. Por outro lado, se não for removida a placa bacteriana aderida ao dente, seu acúmulo pode provocar o aparecimento de sangramento gengival, que se agravará na idade adulta com o aparecimento das periodontopatias, podendo chegar às perdas dos dentes (MACEDO $\left.{ }^{58}, 1986\right)$.

A investigação sobre as funções do fio dental na presente pesquisa sugerem conhecimento incompleto por parte dos professores. Estudos de SANTOS et al. ${ }^{93}, 2003$, com professores, referiram que a crença de que o fio dental tem como função limpeza dos dentes ou remoção dos restos de alimentos, sugerem a utilização do fio dental somente quando comem alimentos sólidos e ficam retidos entre os dentes. Na presente pesquisa, a maioria das respostas se concentravam entre limpar entre os dentes, remover restos de alimentos, não havendo citação de remover as placas bacterianas entre os dentes (tabela 21). Quando, nas respostas evidenciou-se a finalidade do uso do fio dental para retirada de tártaros, pode-se supor haver confusão com o procedimento que é realizado pelo dentista nos seus consultórios, com o termo remoção da formação da placa interdental, semelhante ao que encontrou SANTOS et al. ${ }^{93}$, 2003, em sua pesquisa. 
CAMPOS E GARCIA ${ }^{19}, 2004$ pesquisaram sobre função do fio dental entre os professores, encontrando também respostas de que o fio dental tem sido utilizado apenas par remoção de partículas sólidas de alimentos presos entre os dentes. SANTOS et al. ${ }^{93}, 2003$, também relataram esses achados em seus trabalhos, referindo sua preocupação, sugerindo que esse assunto deva ser bem delineado quando tratado dentro dos programas de saúde bucal, e também nos cursos de capacitação direcionados para professores e população em geral, pois a citação remover restos de alimentos e limpeza dos dentes são sempre as mais lembradas por todos.

A efetividade do selante de fóssulas e fissuras nas superfícies oclusais dos dentes recém-irrompidos é uma das mais efetivas medidas preventivas, principalmente em crianças que apresentam risco de cárie, seja por higiene bucal deficiente, dentes permanentes irrompendo, superfícies oclusais pouco mineralizadas, ou dieta muito cariogênica. Não é muito conhecido pelo público, pois é um procedimento realizado nos consultórios pelos dentistas, porém são necessários nesta fase de idade, porque os dentes permanentes estão irrompendo, e ainda pouco mineralizados. Embora seja procedimento do dentista, conhecer sobre a finalidade dos selantes favorece o aconselhamento aos pais e às crianças. Principalmente saber 
incentivar os alunos a serem receptivos quanto aos métodos preventivos para proteger as superfícies oclusais dos dentes em erupção, principalmente orientando aquelas crianças com higiene bucal deficiente.

Os autores SANTOS, RODRIGUES E GARCIA ${ }^{93}, 2003$, pesquisaram professores sobre esse assunto e encontraram $21 \%$ que desconheciam selantes, $25,9 \%$ referiram-se a ele como material isolante que previne cárie, $27,2 \%$ verniz que forma uma película protetora, e só $2,5 \%$ relataram ser uma resina líquida aplicada nas fóssulas e fissuras dos dentes. $\mathrm{Na}$ presente pesquisa observou-se que os dados sobre desconhecer selantes (figura 9 e 10), mostraram valores maiores do que os de SANTOS et al. ${ }^{93}, 2003$, pois $59 \%$ dos professores pesquisados na presente pesquisa desconheciam selantes. Dos $41 \%$ que responderam saber citaram-no como proteção do esmalte (47\%), material sobre o dente (28\%) e prevenção à carie (20\%). Não houve citação explicando ser resina fluida para fóssulas e fissuras, conforme relatou o autor referido acima em sua pesquisa.

Com relação às respostas dos professores, na presente pesquisa, que referiram como finalidade do selante agir como prevenção à cárie, esse grupo demonstrou que sabia de sua atuação preventiva, mesmo sendo esse material utilizado pelo dentista no consultório. Muitos, ao fazerem 
essa referência, comentavam que levavam seus filhos ao dentista e passavam selante para prevenir cárie.

Aos que nada sabiam sobre esse questionamento, no final da entrevista eram informados sobre os conceitos, e o selante era sempre motivo para explicações, o que deixa claro que é pouco conhecido entre a população.

6. 6. Conhecimento da existência de manual de saúde geral e bucal na escola.

A investigação sobre a existência de literatura pertinente ao assunto teve o propósito de conhecer o interesse do professor em utilizar esses livros- texto para preparar as informações aos alunos. Acreditava-se que, se fosse de utilidade comum, todos responderiam positivamente. Os dados revelaram que muitos professores desconheciam a existência dessa literatura específica (figuras 11 e 12). Os que informaram que os manuais existiam mostravam entonação de dúvida ao responder, o que pode sugerir que não os usavam para consultas. Citaram livros de ciências, mas eram usados só quando havia conteúdo do assunto. Referiram que o dentista trazia algum livro quando vinha fazer alguma palestra e que em seguida o levava.

Essa dificuldade de ter apoio com material didático adequado foi também sentida por vários autores, que 
relataram que os professores manifestavam que tinham dificuldades de encontrar literatura didática sobre saúde e saúde bucal. Os livros que as escolas tinham eram pouco apropriados. Esses dados foram confirmados e observados também por LANG ${ }^{51}, 1989$, GLASRUD $^{41}$, 1998, POMARICO ${ }^{84}$, 2000, em suas pesquisas.

Neste presente trabalho, observou-se que várias escolas visitadas manifestaram as mesmas dificuldades, comprovando o que revelaram os autores citados.

Mencionaram também os professores da presente pesquisa que não tinham um local apropriado para ter livros ou leitura ou biblioteca, nem para professores ou para alunos. Dependiam de verbas ou doações para serem montadas.

TEMPORINI ${ }^{101}, \quad 1988$, avaliou a percepção de professores sobre seu preparo em saúde do escolar e afirmou que professores com treino insuficiente sentiam-se menos à vontade para lidar com distúrbios de saúde do aluno. Referiu, também, que uma boa parte não sabia utilizar um proposto manual de ensinamentos em saúde que a escola tinha recebido, talvez por deficiência na sua formação ou também por ausência de motivação, iniciativa ou liderança.

Acredita-se que havendo literatura apropriada em saúde, direcionadas ao ensino fundamental, caracterizada para as diferentes idades, e se os professores recebessem treinamento de como utilizá-las, haveria a possibilidade de a 
mesma se tornar um forte apoio desse assunto, na difícil tarefa de ensinar crianças.

Em outros estudos MWANGOS ${ }^{71}, 2001$, em Zanzibar, destacou limitações para os professores a respeito de melhorar seu conhecimento de saúde bucal. Citaram que dificuldades tais como: ausência de apoio, ausência de recursos para literatura e falta de reforço do pessoal profissional da saúde colaboram para reduzir suas motivações em oferecer ensinamentos de educação em saúde na escola.

Se por um lado este presente trabalho concordou com outros estudados, que encontraram evidentes necessidades de melhor reforço científico e de práticas em saúde bucal para os professores, por outro destacou a pesquisa de HILGERT ${ }^{46}$, 2001, com professores de escolas públicas de Porto Alegre-RS. Demonstrou a pesquisa da autora referida resultados bem diferentes e positivos, mostrando muito interesse e criatividade dos educadores nesse campo de ensinamento em saúde bucal. Investigados sobre suporte teórico do ensino fundamental que utilizavam, apontavam documentos oficiais vindos do campo educacional e livros indicados na disciplina de Educação em Saúde dos cursos superiores de formação pedagógica que realizaram, contidos nos livros como material de apoio pedagógico em Saúde Bucal. Utilizavam também outras fontes de informação como dentistas (seus próprios dentistas ou pais e mães de alunos 
da escola que eram dentistas), e ainda recursos como CDROM e consultas à Internet. Havia registros individuais dos professores, relatando com suas palavras as diferentes atividades em educação em saúde bucal que realizaram com os alunos durante o ano.

Segundo FERREIRA ${ }^{31}$, 2005, estudando alunos concluintes em Pedagogia, da Universidade Federal da Paraíba, observou que havia deficiência nos currículos acadêmicos quanto a reter conhecimentos de saúde bucal nesses futuros professores. Também LEONELLO, L'ABBATE ${ }^{4}$, 2005, estudaram a percepção de graduandos em Pedagogia, de uma Universidade Estadual Paulista, na abordagem de Educação em Saúde no currículo atual e encontraram que a maioria, $72,5 \%$ dos entrevistados, consideraram que o currículo acadêmico não é objetivo na abordagem de educação em saúde na escola. O que demonstrou, com esses dados, que há ainda um despreparo tanto dos que estão na ativa há algum tempo como também dos que estão para iniciar a carreira do magistério, e há muito por se fazer por eles em qualquer tempo da profissão.

\section{7. Conhecimento sobre traumatismo dentário.}

Quando acidentes acontecem em escolas causando injúrias dentais, cuidados imediatos são necessários a tomar, principalmente quando a criança sofre queda na escola e 
traumatiza na área da boca. Tanto o professor como qualquer outra pessoa da equipe escolar devem estar preparados para socorrer adequadamente, pois um socorro imediato acompanhado de atitudes rápidas e seguras favorecem o prognóstico quando ocorre uma avulsão dental. Estudos mostram que muitas dessas ocorrências acontecem no ambiente escolar (ROBERTSON e NOREN ${ }^{89}, 200$, PACHECO et al. $\left.{ }^{73}, 2003\right)$.

Segundo os autores, os professores ou qualquer profissional da equipe escolar devem sempre trabalhar as crianças com orientações preventivas, para evitar acidentes traumáticos que são comuns nos horários de intervalos e de recreio. Seria aconselhável a escola ter protocolos de fácil acesso sobre os procedimento nesses casos.

Um bom conhecimento sobre socorrer traumatismo buco-dental é relevante, pois ajudará no sucesso do procedimento a ser feito pelo dentista quando atender essa criança. Quanto à importância dessas informações aos educadores, SGAN-COHEN ${ }^{95}$, 1999, manifestou que os conhecimentos e atitudes dos professores de ensino fundamental devem ser avaliados no que diz respeito à etiologia, evolução e prevenção da cárie dental, doença periodontal e traumatismos dentais. E, a partir desses estudos, poder estabelecer novos ensinamentos e reforçar os conhecimentos que devem ser passados nas práticas 
educativas em saúde bucal e no contexto de traumatismos. Deve-se despertar as escolas e professores para a necessidade de prevenção aos acidentes nas escolas, projetar protocolos de atendimentos, estimular confecção de quadros ou "posters" para as escolas deixarem expostos, visíveis, informando como proceder em acidentes envolvendo traumas bucais.

Os autores PACHECO et al. ${ }^{73}, 2003$ e TRAEBERT et al. ${ }^{103}, 2001$, que estudaram o assunto, citaram que quanto mais rápido o dente deslocado for colocado no alvéolo, melhor será a possibilidade de sucesso do reimplante dental quando realizado. Daí a preocupação de reforçar esses ensinamentos aos professores, os quais são simples e de grande utilidade nesse aspecto. TROPE ${ }^{104}$, 2006, refere um tempo favorável dentro de 15 a 20 minutos, para reimplantar um dente avulsionado.

Não havendo possibilidade de fazer esse procedimento no local da escola, o dente deve ser armazenado, segundo TROPE ${ }^{104}, 2002$, em recipiente na seguinte ordem de preferência indicada: leite, saliva, ou colocar o dente na região vestibular da boca da criança, ou em recipiente onde se coletou saliva do paciente, ou soro fisiológico, ou como última preferência, a água.

Pesquisas de PACHECO et al. ${ }^{73}, 2003$ relataram avaliação de professores de ensino fundamental do Rio de 
Janeiro sobre avulsão dental. Investigaram sobre: 1 - O que eles fariam ao socorrer avulsão e 2 - Como armazenariam o dente avulsionado, muito semelhante ao questionamento do assunto da presente pesquisa.

No primeiro questionamento da pesquisa de PACHECO et al. ${ }^{73}, 2003,57,1 \%$ responderam que levariam a criança imediatamente ao dentista, 14,3\% limpariam a boca da criança com guardanapo e guardariam o dente em gaze, $14,3 \%$ chamariam os pais, $14,3 \%$ recolocariam o dente no alvéolo e correriam para o dentista. Na presente pesquisa, dos $77 \%$ que disseram saber como socorrer o traumatismo (figura 13), quando o questionamento visava a investigar como fariam para socorrer a criança acidentada (tabela22), as respostas mais adequadas foram estas: $50,85 \%$ referiram levar ao dentista, 30,51\% guardar o dente, 11,86\% levar rápido ao dentista, 9,32\% levar ao Pronto Socorro (PS) (pois lá existem sempre dentistas no plantão) e 5,93\% citaram reimplantar. As citações levar rápido ao dentista, reimplantar e guardar o dente sugerem que esses professores têm o conhecimento emergencial da necessidade de ser recolocado o dente no alvéolo rapidamente ou transportar rápido a criança e o dente para o dentista recolocar o dente avulsionado. O restante das citações sugeriram conhecimento intuitivo, fragmentado, quanto ao procedimento emergencial, 
semelhante ao que mencionou PACHECO et al. ${ }^{73}, 2003$, em sua pesquisa.

Trabalhos de CORRÊA et al. ${ }^{25}, 2005$, constataram que a melhor opção para guardar o dente até chegar ao consultório ou clínica é colocá-lo na própria saliva (da criança) ou em recipiente com saliva coletada do paciente, ou colocá-lo no leite ou soro fisiológico. A água não é considerada boa opção pois causa um meio hipotônico, provocando rápida lise celular e aumentando a inflamação na área reimplantada.

$\mathrm{Na}$ investigação seguinte da presente pesquisa, observou-se quais as citações dos professores de Bauru, sobre o líquido em que armazenariam o dente caso a criança fosse levada ao dentista para reimplantá-lo. A maioria ,36\%, respondeu colocar o dente na água. Segundo CORRÊA et al. ${ }^{25}$, 2005, como já citamos acima, a água não é a melhor indicação, pois provoca reação inflamatória na região implantada, sendo a saliva, leite e soro as melhores opções. Portanto, essa foi a opção mais referida (36\%) pelos professores para armazenar um dente avulsionado, o que remete à necessidade de atualizá-los nesse quesito (Figura 14).

Podemos destacar, ainda, que o presente estudo evidenciou sugestões de práticas educativas acerca da educação em saúde bucal, visando a envolver todas as 
camadas sociais da população (escolares, professores e comunidade em geral), no sentido de bem direcioná-las para a área da saúde coletiva. Os autores citados, a seguir, referiram esses temas nos estudos dos professores, devido às dificuldades por eles mencionadas em encontrar material de apoio didático.

Acredita-se que muitos desses trabalhos foram produzidos para desenvolver atividades práticas com os alunos, facilitando a sua compreensão. Observou-se que temas em saúde bucal provocam pouco interesse na população, além de dificuldades de assimilar certos conceitos, termos técnicos e específicos, os quais necessitam ser decodificados, e simplificados ao ensinar a comunidade. É reconhecido que existem deficiências encontradas pelos professores de primeiro e segundo grau quando necessitam de elementos para seu trabalho de abordar saúde bucal na sala de aula, possivelmente por essas dificuldades.

Estudos de MELO ${ }^{65}, 2005$, citaram que é fundamental que os professores tenham acesso aos conceitos científicos, porém estes devem ser desenvolvidos em forma de aplicação em treinamentos práticos, para que os mesmos possam ser melhor absorvidos.

Nesse contexto os autores GUIDA, VASCONCELOS e VASCONCELOS ${ }^{42}, 1994$, projetaram uma literatura apropriada baseada em pesquisa realizada com professores de escolas 
públicas em Nova Friburgo, Rio de Janeiro, sobre o assunto. Elaboraram o livro "Odontologia na sala de aula e na comunidade, saúde bucal e prevenção ", numa linguagem e apresentação simples, mas com valor cientifico, oferecendo também sugestões de atividades didáticas, o qual serviu de apoio na ação dos professores de ensino fundamental da região em Nova Friburgo onde foi publicado.

Com vistas ainda à filosofia das práticas preventivas da Saúde Coletiva em Odontologia, um outro modelo de atenção foi criado (2006) com esforços para melhorar a qualidade da atenção odontológica, priorizando medidas de prevenção e controle das doenças bucais, com destaque para educação em saúde. "O projeto Saúde Marajoara", de MACEDO et al. ${ }^{57}$, em 2006 , os quais criaram uma "Cartilha Saúde Bucal do Meu Aluno", objetivou dar apoio e amenizar as dificuldades das escolas em Marajó, principalmente da rede pública de ensino, voltado a atingir alunos e professores. Segundo os autores, estando a saúde bucal norteando essas ações, devendo então ser agentes notáveis da diminuição da doença cáries, desde que inseridos em um modelo de prática odontológica que contemple o controle da doença, e não apenas a eliminação dos sintomas. Essa Cartilha foi distribuída para todos os professores que estavam envolvidos no projeto, para gerar resultados práticos e foi de grande amplitude na sua utilização. Foi elaborada 
com conteúdo dirigido para a conscientização da importância da saúde bucal, e de maneira clara e sensível à realidade vivenciada nos meios escolares, ou seja, adaptada ao nível cultural dos alunos, sendo prática, atrativa e comunicativa. (MACEDO et al. $\left.{ }^{57}, 2006\right)$

Um programa inovador de saúde escolar foi elaborado por DRUMOND 29,2004 , que criou metodologia permitindo às escolas e creches de Belo Horizonte, estado de Minas Gerais, para obter medidas de autocuidado e manter a motivação da comunidade. Para melhorar a percepção da saúde bucal de crianças e de professoras em creches e escolas, sistematizou-se o auto-exame bucal, que possibilitou à comunidade acompanhar os resultados do programa. Consistiu essa estratégia de uma oficina de capacitação com professoras e utilização de planilha para, a partir da contagem dos dentes da criança, instituir a prática do autoexame bucal. Ao detectar algum dente com aspecto carioso, contatavam a Unidade Básica para atendimento.

Os autores sugeriram essa metodologia para grupos populacionais em situação econômica desfavorável, os quais devem ser priorizados por tais projetos, para que possam ter acesso ao exercício pleno da cidadania.

Ao desenvolver práticas direcionadas aos professores de pré-escolas até a $4^{a}$ série em municípios do interior de Goiás, MORAIS ${ }^{70}$, 1999, organizou oficinas de 
capacitação para os professores, após trabalhar primeiro com os alunos em Saúde Bucal em aulas normais, assim como outras disciplinas o fazem, e com apostilas que iam sendo montadas aula por aula, com colagens, figuras e espaços para informações. Os professores, no início, recebiam uma apostila com material didático auxiliando os professores nas aulas a serem desenvolvidas durante o ano. Também tinham de responder a um questionário para avaliar o conhecimento. No final, os professores recebiam certificados assinados pelo Prefeito Municipal, Secretária da Saúde, Secretária da Educação e do ministrador do curso. Isso proporcionou muita satisfação e interesse nos professores. Citou o autor que o apoio da escola foi de extrema importância. Os professores depois de treinados, passaram a ministrar aulas sobre saúde bucal a todas as crianças que freqüentavam a escola até a $4^{a}$ série.

As informações obtidas através do presente estudo finalizado, possibilitaram concordância com várias citações dos autores que avaliaram professores em suas pesquisas, no sentido de que é necessário que os profissionais da educação sejam preparados desde a sua formação universitária, e depois em educação continuada. Dessa maneira, serão mais instruídos e treinados nos conhecimentos de educação em saúde bucal. Poderão ficar mais seguros, comprometidos e motivados nos ensinamentos, para, assim, 
influenciar positivamente as crianças na construção de seus hábitos saudáveis e de um futuro melhor, possibilitando uma qualidade de vida melhor (VASCONCELOS ${ }^{110}, 2001$ ).

As medidas preventivas que estudamos em Saúde Coletiva, mais os conhecimentos aplicados nas várias práticas educativas, fazem ressurgir a prevenção, forte, concreta, como proposta alternativa para melhores índices em saúde bucal.

Diariamente os professores estão na frente de trabalho com os estudantes, sejam eles crianças na maioria das vezes, mas também os adolescentes e adultos. Esses profissionais são, junto com os pais, os responsáveis pela formação moral e educacional dos alunos e conhecem como ninguém mais seus anseios e dificuldades, possuindo adestramento específico para melhor escolher quando empregar os conhecimentos oferecidos pela ciência, portanto precisam do nosso total apoio.

FLORES ${ }^{33}$, 1999, afirmou que quando os saberes são produzidos e repassados, no processo informal de educação, a relação se estabelece de modo pessoal, mediada de confiança e pela identificação entre seus sujeitos, no espaço de suas experiências de vida.

Se todos fizerem sua parte, tanto da saúde como da educação, e mais os que decidem as reformas educacionais, sejam Ministérios, Secretarias, Universidades, ou governos, e 
até mesmo as ações das organizações populacionais, juntos, vislumbraremos um novo horizonte surgindo, para se caminhar em busca de uma situação ideal de educar em saúde, promovendo saúde em primeira categoria no ensino público básico dos brasileiro.

Finalizando, após reflexões no término deste trabalho, pensou-se em preparar algo concreto com informações retiradas do presente trabalho de pesquisa, que possa contribuir como um apoio didático aos professores pesquisados. Está sendo criado um guia prático em Saúde Bucal, adicionado de conteúdos científicos, dissolvidos em uma linguagem simples, fácil de ser aplicada, contendo também sugestões de atividades, para facilitar a compreensão dos alunos, e que será impressa em futuro próximo.

Estes estudos induziram a se pensar em um projeto para treinamento em saúde de professores de escolas de $1^{\mathrm{a}}$ a $4^{\mathrm{a}}$ série. Este deve ser realizado em forma de "Oficina em Saúde: para professores de ensino fundamental" com parte teórica e prática, no próprio ambiente escolar. 


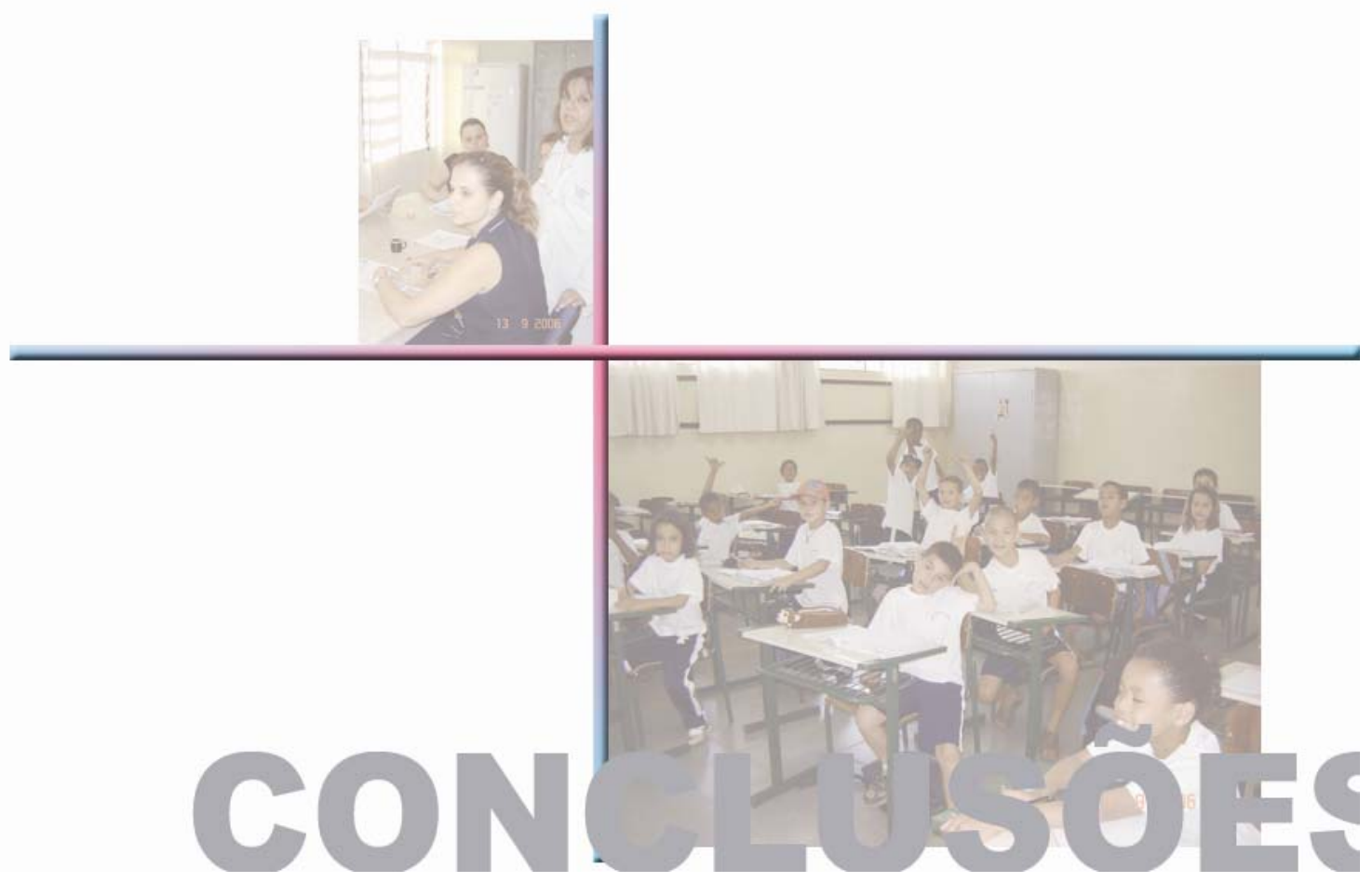

CONCLUSÕES 


\section{7- CONCLUSÕES}

Pelos resultados obtidos foi possível verificar que:

Os professores pesquisados, na sua maioria, têm conhecimentos sobre saúde bucal, embora muitos desconheçam alguns conceitos.

Registraram-se atitudes positivas de interesse, quando se observou que muitos passavam para os alunos seus conhecimentos de saúde geral e bucal, e também orientavam sobre métodos de higiene bucal. Por outro lado, ainda existe resistência de alguns em considerar essa responsabilidade como sendo sua. Com respeito aos cuidados com sua própria saúde bucal, verificou-se que a maioria possui conhecimentos satisfatórios, porém não utilizando totalmente essa prática para desenvolver ensinamentos.

Quanto aos conhecimentos etiológicos e preventivos das doenças bucais e medidas preventivas, apresentam conhecimentos incompletos, sendo necessário reforços científicos delineando esse assunto.

Com relação às origens de seus conhecimentos, a referência maior foi aquela advinda de cirurgiões-dentistas, escolas, mídia e família, porém grande parte nunca fez treinamentos em saúde bucal, o que remete à necessidade de incentivar essas práticas. 
Os conceitos sobre traumatismos dentais mostraram-se de pouca consistência, sendo importante atualizar esse assunto.

É preciso investir no preparo dos professores, seja por meio de elaboração de material educativo de fácil manuseio e também, oferecendo-lhes treinamento em saúde bucal nas escolas, visto que muitos não receberam essa prática. 


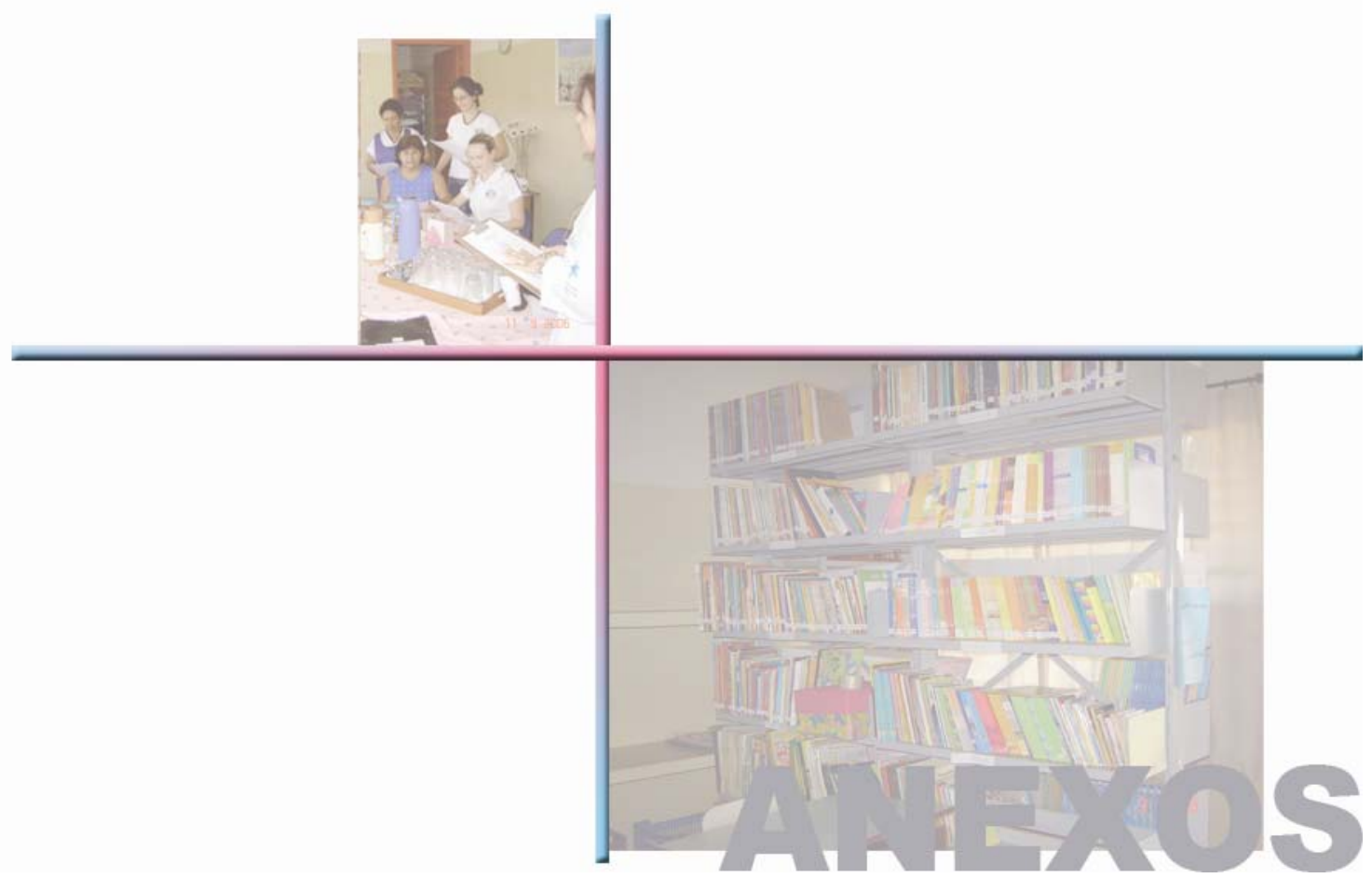

ANEXOS 


\section{1- Cópia do ofício enviado 'a Delegacia Regional de Ensino, solicitando autorização para realizar a pesquisa.}

\section{À DELEGACIA REGIONAL DE ENSINO DE BAURU.}

IImo Sr(a). Delegado(a) de Ensino de Bauru.

Prezado Senhor(a).

Vimos por meio deste documento solicitar autorizaçăo para realizar uma pesquisa cientifica propondo entrevistar professores do ensino fundamental de escolas de Bauru, pertencentes a essa Delegacia de Ensino, com objetivo de colher informaçöes sobre promoção de saúde bucal em sala de aula. A entrevista será feita individualmente pela mestranda Rute Moreira de Freitas Sant'Anna, do Departamento de Saúde Coletiva da Faculdade de Odontologia de Bauru - USP, como parte do trabalho científico que está realizando.

Informamos que o projeto dE pesquisa passará pelo julgamento do Comitê de Ética da FOB-USP-Bauru e só será executado se aprovado pelo mesmo.

Ao final da pesquisa os resultados serăo enviados para a Delegacia de Ensino para conhecimento, e os professores receberão um manual atualizado sobre educação em saúde bucal.

Agradecemos pela atenção dispensada.

Atenciosamente.

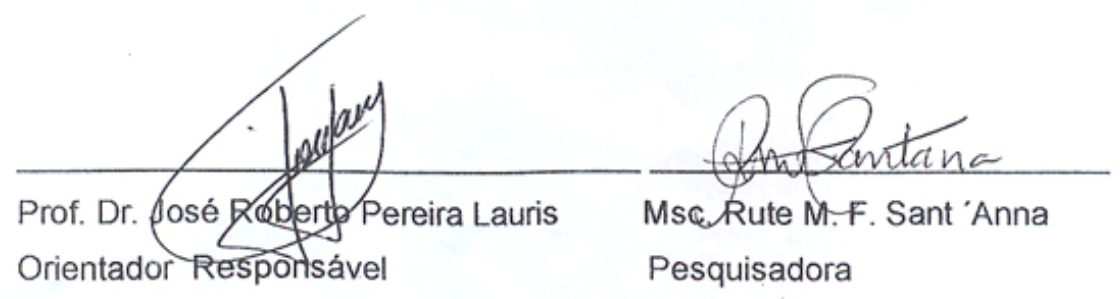

Orientador Respontsável

Pesquisadora

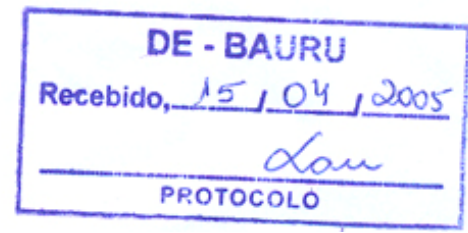


2- Cópia da autorização para realização da pesquisa da Secretaria de Educação, da Prefeitura Municipal de Bauru.

\author{
PREFEITURA DO MUNICÍPIO DE BAURU \\ Estado de São Paulo \\ SECRETARIA DA EDUCAÇÃo \\ Fone: (14) 3234-1977 \\ End: Rua Padre João, 8-48 - Vila Regis. \\ CEP: 17014-003 \\ Email: educacao@bauru.sp.gov..br
}

\title{
AUTORIZAÇÃO
}

\begin{abstract}
Após a leitura detalhada do projeto de pesquisa intitulado "AVALIAÇÃO DO CONHECIMENTO SOBRE SAÚDE BUCAL DE PROFESSORES DE ESCOLAS DE ENSINO FUNDAMENTAL DO MUNICÍPIO DE BAURU-SP" e, tendo avaliado os objetivos nele explicitados, autorizo a Mestranda Rute Moreira de Freitas Sant'Anna, do Departamento de Saúde Coletiva da Faculdade de Odontologia de Bauru - USP, a desenvolver a fase de coleta de dados enunciados nesses projeto, em dez Escolas Municipais de Ensino Fundamental no município de Bauru, seguindo detalhamento apresentado na Metodologia de referido Projeto.
\end{abstract}

Bauru, 05 de Agosto de 2005.

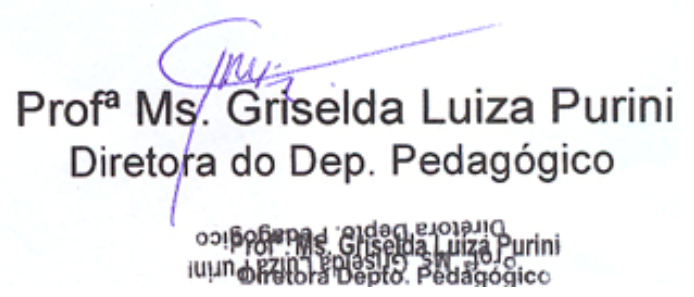


3 - Cópia da autorização para realização da pesquisa da Delegacia Regional de Ensino.

\author{
SECRETARIA DE ESTADO DA EDUCAÇÃO \\ COORDENADORIA DE ENSINO DO INTERIOR \\ DIRETORIA DE ENSINO - REGIÃO DE BAURU
}

\title{
AUTORIZACÃO
}

Após a leitura detalhada do Projeto de Pesquisa intitulado "AVALIAÇÃo DO CONHECIMENTO SOBRE SAÚDE BUCAL DE PROFESSORES DE ESCOLAS DE ENSINO FUNDAMENTAL DO MUNICÍPIO DE BAURU-SP" e, tendo avaliado os objetivos nele explicitados, autorizo a Mestranda Rute Moreira de Freitas Sant'Anna, do Departamento de Saúde Coletiva da Faculdade de Odontologia de Bauru - USP, a desenvolver a fase de coleta de dados enunciadas nesse projeto, em dez Escolas Estaduais de Ensino Fundamental no municipio de Bauru. As Unidades Escolares serão definidas posteriormente, conforme detalhamento apresentado na Metodologia do referido Projeto. **

Bauru, 09 de Maio de 2005.

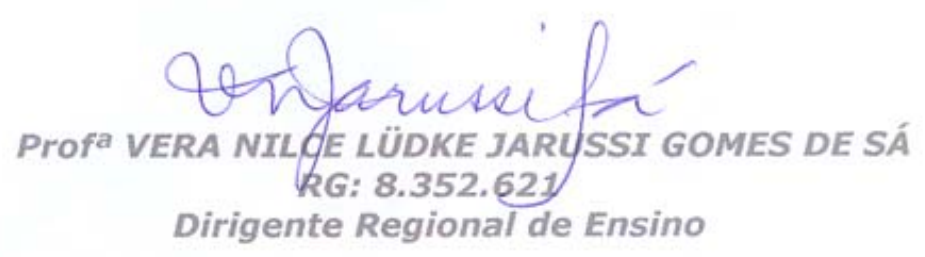




\title{
4 - Cópia da aprovação do projeto pelo Comitê de Ética em Pesquisa.
}

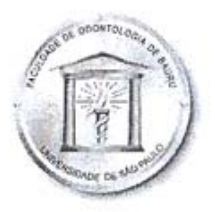

\author{
Universidade de São Paulo \\ Faculdade de Odontologia de Bauru
}

Al. Dr. Octávio Pinheiro Brisolla, 9-75 - Bauru-SP - CEP 17012-901 - C.P. 73

PABX (0XX14)3235-8000 - FAX (0XX14)3223-4679

Comitê de Ética em Pesquisa

Processo $n^{\circ} 82 / 2005$

Bauru, 01 de setembro de 2005.

Senhor Professor,

O projeto de pesquisa encaminhado a este Comitê de Ética em Pesquisa em Seres Humanos, denominado "Avaliação do conhecimento de saúde bucal de professores de escolas de ensino fundamental do município de Bauru SP", de autoria de Rute Moreira de Freitas Sant'Anna, que será desenvolvido sob sua orientação, foi enviado ao relator para avaliação.

$\mathrm{Na}$ reuniäo de 31 de agosto de 2005 o parecer do relator, aprovando o projeto, foi aceito pelo Comitê, considerando que não existem infrações éticas pendentes.

Informamos que após o envio do trabalho concluido, este Comitê enviará o parecer final, que será utilizado para publicação do trabalho.

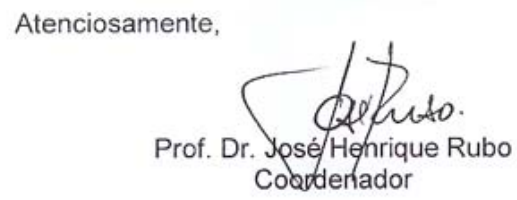

$\| m^{\circ} \mathrm{Sr}$. Prof. Dr. José Roberto Pereira Lauris

DD. Docente do Departamento de Odontopediatria, Ortodontia e Saúde Coletiva 
5 - Cópia do termo de consentimento livre e esclarecido, e informação ao participante.

\author{
UNIVERSIDADE DE SÃO PAULO \\ FACULDADE DE ODONTOLOGIA DE BAURU \\ DEPARTAMENTO DE SAÚDE COLETIVA
}

\title{
CARTA DE INFORMAÇÃO
}

Cidadania é podermos participar individualmente para a melhoria do coletivo, e colaborarmos com o planejamento das açōes.

Estamos realizando uma pesquisa nos professores da rede de ensino fundamental, da $1^{\text {a }}$ a $4^{\text {a }}$ série da cidade de Bauru, sobre o conhecimento de saúde, que este adquiriu durante a sua formação profissional.

Respeitosamente pedimos que participe do nosso trabalho e assine o consentimento livre e esclarecido. Por isso precisamos de sua cooperação respondendo ao questionário individual, que será realizado em forma de entrevista.

Os resultados obtidos poderäo ser publicados em jornais e/ou revistas cientificas, sendo assegurada o total sigilo da identidade do participante

A responsável por esta pesquisa é a Cirurgiä-Dentista e mestranda Rute Sant'Anna que se encontra à disposição para qualquer dúvida pelo telefone: 32231571 ou $9143-8284$.

Caso o sujeito da pesquisa queira apresentar reclamaçōes em relação a sua participação na pesquisa, poderá entrar em contato com o Comitê de Ética em Pesquisa em Seres Humanos, da FOB-USP, pelo endereço da Al. Octávio Pinheiro Brisola, 9-75(sala no prédio da Biblioteca, FOB-USP) ou pelo telefone ( 14) 3235-8356.

TERMO DE CONSENTIMENTO LIVRE E ESCLARECIDO

Pelo presente instrumento que atende às exigências legais, o Sr. (a)

portador da cédula de identidade após leitura minuciosa da CARTA DE INFORMAÇÄO AO PARTICIPANTE, devidamente explicada pelos profissionais em seus minimos detalhes, ciente dos serviços e procedimentos, não restando dúvidas do lido e explicado, firma seu CONSENTIMENTO LIVRE E ESCLARECIDO concordando em participar da pesquisa proposta.

Fica claro que o participante pode a qualquer momento deixar de participar desta pesquisa.

Declaramos que a identidade de nenhum participante será divulgada, e que este trabalho segue todas as normas do comitê de Ética em pesquisa da Faculdade de Odontologia de Bauru, e segundo o Artigo $9^{\circ}$ do Código de Ética Odontológica serão guardadas confidencialmente as informaçöes prestadas por respeito ao sigilo profissional.

Por estarem de acordo assinam o presente termo.

Bauru-SP, de

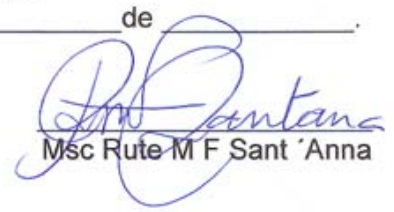

Assinatura do participante 
6- Cópia do modelo de questionário aplicado.

\section{Questionário}

NOME DA ESCOLA:

Data / /

1.Escola ( ) Estadual ( ) Municipal ( ) Particular

3. Identificação $n^{\circ} \quad$ 4. Sexo ( ) feminino ( ) masculino ( )

5. Idade ( ) 6. Tempo de serviço __ anos.

7. Renda familiar ( total)

$\mathrm{R} \$ 400,00$ a 1 mil reais（） 1 a 3 mil reais（） 3 a 6 mil reais ( )

6 a 9 mil reais ( ) mais de 9 mil reais ( )

8. Possui:

( ) Curso Superior ( ) Especialização

( ) Mestrado ( ) Doutorado ( ) Não

1-Troca de escova de dente regularmente?

( ) Sim A cada ( ) mês( ) 2 meses

( ) 3 meses ( ) 6 meses ( ) 1 ano ( ) Não

2- Traz escova de dentes para o trabalho?
( ) sim
( ) não

3- Quantas vezes por dia escova os dentes?

4- Fala sobre saúde geral em sala de aula?
( ) sim
( ) não. Por quê? -

5-Durante as aulas dá orientação como fazer higienização bucal?
( ) sim
( ) não. Por quê? -

6- Se não: existe alguém que dá essas orientações?

( ) $\operatorname{sim}($ ) não 
7-Fala sobre importância da saúde bucal para seus alunos?

$$
\text { ( ) sim ( )não }
$$

8- De onde recebeu informaçōes sobre saúde bucal?
( ) mãe
( ) familia ( ) escola ( ) amigos
( ) televisão ( ) UBS (Unidade Básica de Saúde)
( ) dentista ( ) cursos ( ) outros

9- Já recebeu treinamento sobre saúde bucal?
( ) não
( ) sim. Como?
( ) palestras pelo $C D$ da escola
( ) curso pela Prefeitura/Estado
( ) dentista particular

Outros especificar

10-Quais as razöes para manter boa higiene bucal?
( ) bom hálito
( ) estética
( ) aparência
( ) saúde
( ) trabalho
( ) relacionamento com pessoas
( ) mastigação
( ) fonética
( ) não sabe ( )outros. Especificar

11-Sabe qual é a função do flúor?
(1) prevenir cáries
( ) deixar dentes brancos
( ) hálito puro
( ) deixar os dentes brilharem
( ) fortalecer os dentes
( ) Proteção
( ) năo sabe

12-Você sabe em quais locais o flúor pode ser encontrado?
( ) não
( ) $\operatorname{sim}$
( ) creme dental
( ) água
( ) dentista
( ) clínicas
( ) leite
( ) alimentos
( ) outros, especificar

13-Você sabe qual é a funçäo do fio dental?
( ) remover restos de alimentos
( ) retirar o tártaro
( ) limpar entre os dentes
( ) não sabe
( ) não usa
( ) usa 
14-Quais as caracteristicas adequadas da escova dental?
( ) cerdas macias
( ) cabeça grande
( ) cerdas médias
( ) cabeça média
( ) cerdas duras
( ) cabeça pequena
( ) não sabe

15-Você sabe o que é selante?
( ) näo
( ) sim O que é?

16-Existem em sua escola manuais de Promoção de Saúde?
( ) não
) $\mathrm{Sim}$
( ) Näo Sabe

17-Existem em sua escola manuais de Saúde Bucal?
( ) não
) $\operatorname{Sim}$
( ) Não Sabe

18-Sabe o que doença é periodontal?
( ) $\operatorname{sim}$
() não

19- E sabe como evitar essa doença?

$$
() \operatorname{sim}(\text { ) năo }
$$

20- Sabe o que fazer na hora se uma criança perde um dente em acidente na escola?

( ) não ( ) sim, explique 
7- Endereço das escolas estaduais e municipais.

NOMES E ENDEREÇOS DE ESCOLAS MUNICIPAIS DE ENSINO FUNDAMENTAL EM BAURU, E RESPECTIVO NUMERO DE PROFESSORES EM CADA ESCOLA

1. EMEF ALZIRA CARDOSO

Rua Orosimbo F Figueiredo 4-45 - Chapadão

Fone 3239-6980

11 professores

2. EMEF "CÔNEGO ANÍBAL DIFRÂNCIA"

Rua Manoel Figueiredo Q 1 - Parque São Geraldo

Fone 3237-2475

11 professores

3. EMEF "GERALDO ARONE"

Rua João Prudente Sobrinho, Q. 5 - N.Fortunato R Lima,

Fone 3238-3499

12 professores

4. EMEF "IVAN ENGLER DE ALMEIDA"

Avenida Maria Ranieri, 1-40 - Parque Dos Sabiás

11 professores

5. EMEF "PROFESSOR JOSÉ ROMÃO"

Rua Pedro de Castro Pereira 8-20 - Nova Bauru

Fone 32373446

17 professores 
6. EMEF "LOURDES OLIVEIRA COLGNAGHI"

Rua Engo João Batista Pacheco Fantin 3-20 - Núcleo J. Regino,

Fone 3203-7624

11 professores

7. EMEF "MARIA CHAPARRO COSTA '“.

Alameda Urano 5-38 - Parque Santa Edwirges

Fone 3238-4448

13 professores

8. EMEF "NACILDA DE CAMPOS"

Rua Joaquim Marciano 5-39 - Vila Garcia

FONE 3239-3462

9 professores

9. EMEF "SANTA MARIA"

Rua Presidente Kennedy 19-97 - Vila Cárdia

Fone 3227-7419

12 professores

10. EMEF "THEREZA TARZIA - IRMÃ ROSAMARIA TARZIA"

Rua Antonio Montebugnolo 6-32 - N. Nobuji Nagasawa

Fone 3237-4616

13 professores

11. EMEF "ETELVINO RODRIGUES MADUREIRA"

Rua Severino De Souza, Q.5, Lado Ímpar

Jardim Flórida/Araruna

FONE 3239-0207

7 Professores 
12. EMEF "PROFESSOR WALDOMIRO FANTIN"

Rua Primo Pegoraro, Q.2 - Leão Xiii/Santa Cândida

Fone 3238-9947

13 professores

13. EMEF "DIRCE BOEMER GUEDES DE AZEVEDO"

Rua Antonio Dezembro, Q. 5 Lado Ímpar - Ferradura Mirim-Tangarás FONE 3281-9271

11 professores

14. NÚCLEO ENS. REN. EDUC. ENS. FUND. LYDIA ALEXANDRINA Nava Cury, Rua Anthero Donnini 1-125 - Geisel

Fone 3203-3769

05 professores

\section{NOMES E ENDEREÇOS DE ESCOLAS ESTADUAIS DE ENSINO} FUNDAMENTAL

1. E E "ANA R.Z. D'ANNUZIATA “.

Rua Prof. Luzia P. Rego 1-70 - Jardim Redentor

Fone 3203-3399

18 professores

2. E E "ANTONIO S. SOBRINHO"

RUA JOSÉ MIGUEL, QUADRA 19 - V. IPIRANGA.

FONE 3236- 1452

22 professores

3. E E "A. X. MENDONÇA"

Rua Romeu Crivell 8-20 - V. Industrial

Fone 3238-1023 
26 professores

4. EE "AYRTON BUSCH"

Rua Prof. Ayrton Busch 14-44 - Pq. Jaraguá

Fone 3238-1117

11 professores

5. E E "H. BERTOLUCCl"

Rua Gabriel P Ribeiro 3-44 - V. Independência

Fone 3236-1300

25 professores

6. E E "JOÃO P. FERNANDES"

Rua Dos Pintores S/N, N.H. Vanuire - Gasparini

Fone $3239-2470$

14 professores

7. E E "JOSÉ RANIERI"

Rua Xerxes R dos Santos 12-40 - P. Hipódromo

Fone 3203-1616

15 professores

8. E E "LUIZ BRAGA"

Rua Fuas De Matos Sabino 126-56 - J. Europa

Fone 3223-0575

20 professores 
9. E E "SALVADOR FILARDI"

Rua Irene O. Nogueira 1-51

N. Esperança

Fone 3238-1337

13 professores

10. E E "TORQUATO MINHOTO "

Rua Silva Jardim 11-22 - J. Bela Vista

Fone 3223-6453

24 professores 
8-Cópia de uma solicitação de mapa de escolas de Bauru para o DAE.

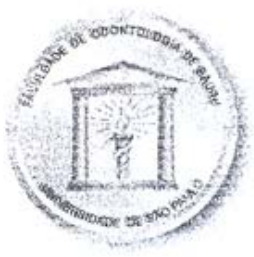

\author{
UNIVERSIDADE DE SÃO PAULO \\ FACULDADE DE ODONTOLOGIA DE BAURU \\ DEPARTAMENTO DE ODONTOPEDIATRIA, ORTODONTIA E. \\ SAÚDE COLETIVA
}

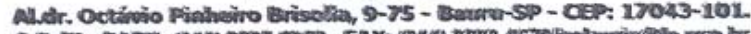

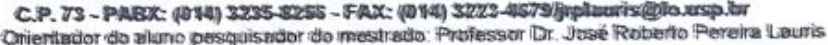

Solicitagäo de mapa de Bauru= escolas

"A presidência do DAE-Bauru

Sr. Josẻ Clemente Rezende

Prezado semhor:

Rute Moreira de Freitas Sant "Amna, R.G. 3.506 529, Cirurgiä-Dentista, CROSP. 16.425, aluna matriculada no curso de mestrado de Odontologia en Saúde Coletiva, do Departamento de Odontopediatria, Ortodontia e Saúde Coletiva, da Facuildade de

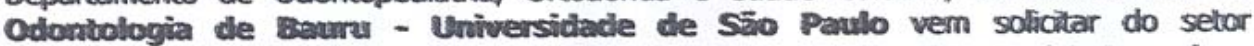
Geoprocessamento do DAE, mapa da cidade de Bauru redurzido, em dois tamanhos, com as escolas de Bauru devidamente destacadas em cores diferentes: uma cor para escollas estaduais e outra cor diferente para escolas municipais (Nomes em anexo).

A finalidade dos mapas é: facifltar visualização, ilustrando a localização das escolas de ensino fundarnental de Bauru do trabatho de pesquisa escrito, destacando os locais das escolas onde foi realizadia a pesçuisa cientíica. Outra finalidade ẽ facilitir explicaçä̀ para banca examinadora na apresentaçäo final EGQ e defesa da Dissertação do curso de mestrado, e também servirá corro figura ilustrativa em Pốster de eventos oientüicos nacionais.

Tamanhos solicitados:

Um mapa da cidade de Bauru, colorido, bonito, com as escolas estaduais e municipais (citadas em anexo), porturadas, se possivel de tamanho reduzido pera folha sut

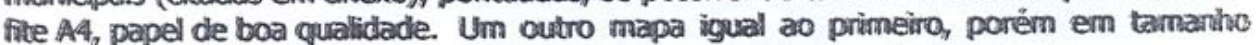
$10 \times 20$ para colocar ern Painel-Poster, papel de boa qualidade, colorido, bonito.

Os custos ficarãio por conta da aluna pesquisadora responsável, quie está também encarregada dos contatos e obtençäo dos mapas. Telefone para contalto: 3223-1571( 12 as 14 horas), ou fore $8131-7923$.

Sem mais, agradecemos pela atençäo e cooperação.

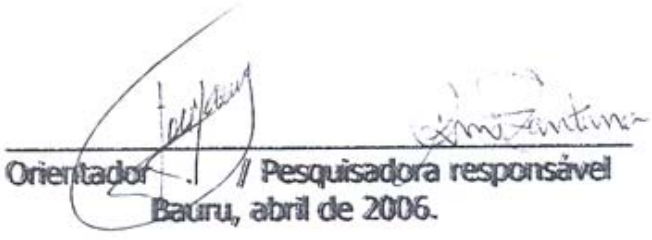


9- Cópia do mapa das escolas e visão dos bairros onde se encontram.

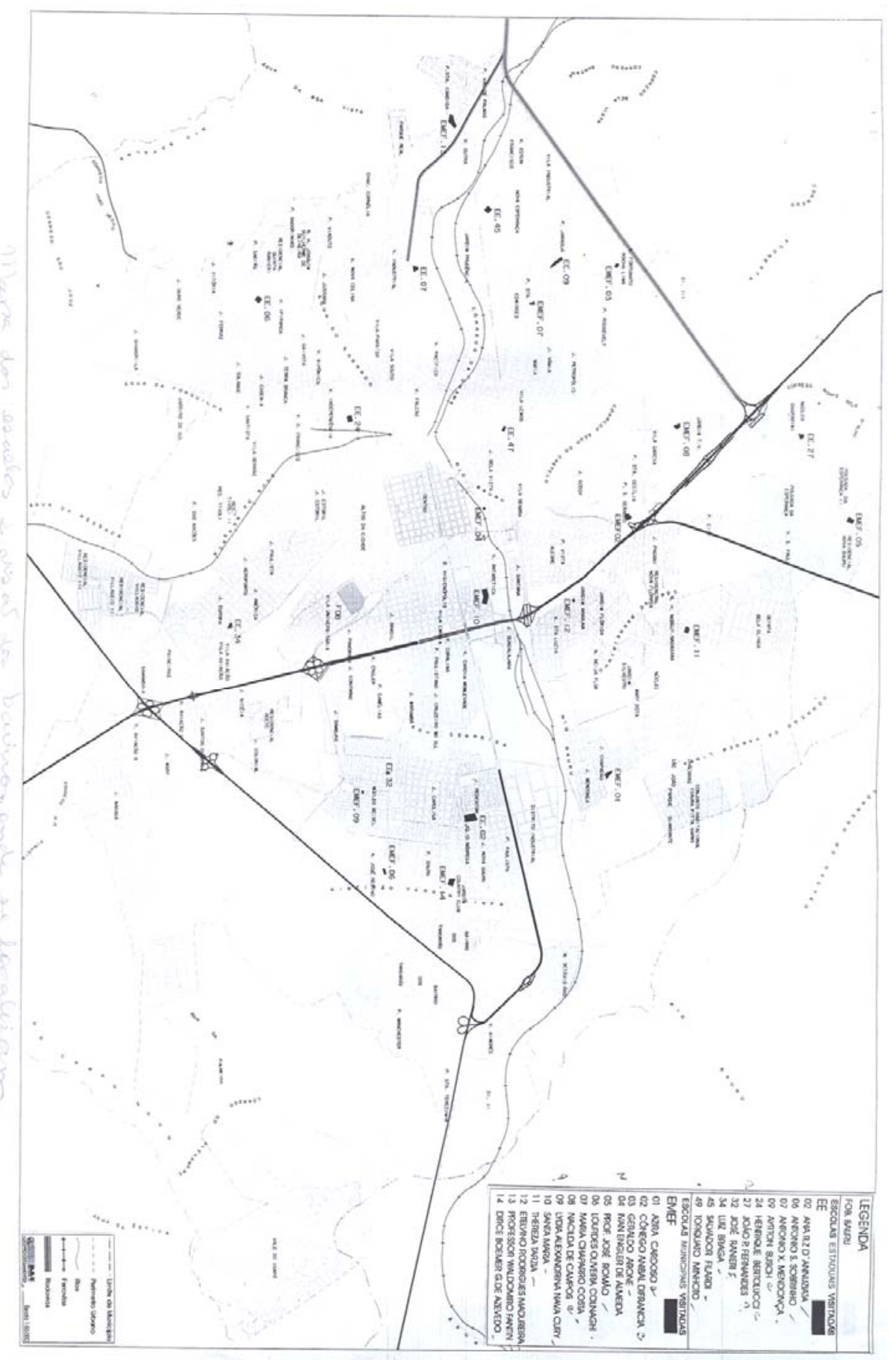




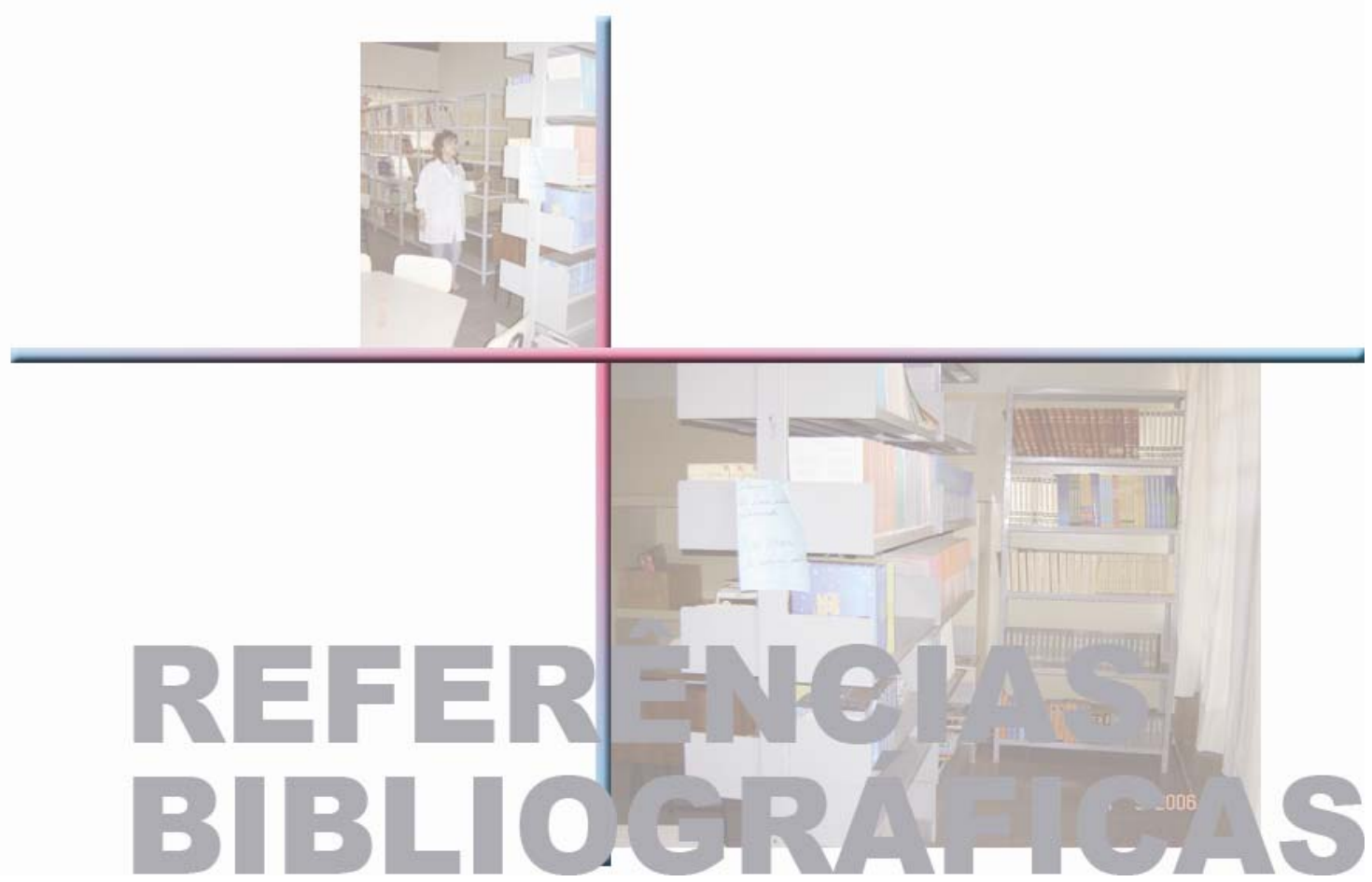

REFERÊNCIAS BIBLIOGRÁFICAS 


\section{REFERÊNCIAS BIBLIOGRÁFICAS}

1_ ABEGG, C. Notas sobre educação em Saúde Bucal nos consultórios odontológicos, unidades de saúde e nas escolas. Rev. Ação Coletiva, Brasília. v. 2, n. 2, p. 25-28, abr/jun. 1999.

2_ Agenda USP de Noticias 2002. Cai o índice de cárie dentária em Bauru. Brasil. Informativo 8/4/2002. Disponível em www.usp.br/agen/bols/2002/rede937.htm

3_ AL-TAMINI, S.; PETERSEN, P. E. Oral health situation os schoolchildren, mothers and schoolteachers in Saudi Arábia. Int Dent J, London, v. 48, n. 3, p. 180-186, June. 1998.

4_ ALVES, M. S. C. F. et al. Conhecimento e atuação em saúde bucal de professores do ensino fundamental. Rev Saúde Natal, v. 15, n. 1, p. 41-48, jan./jun. 2001.

5_ ANTUNES, C., O significado ser professor. Disponível em http: I/www.celsoantunes.com.br. Acesso em 09/09/2006.

6_ AQUILANTE, A. G. et al. Importância da educação em saúde bucal para pré-escolares. Rev Odontol da Unesp, São Paulo, v. 32. n. p. 39-45, 2003. 
7_ $\quad$ ARNEBERG, P.; SAMPAIO, F. C. Fluoretos: promoção de saúde na clínica odontológica. São Paulo: Artes médicas, 2000. p. 214-245.

8_ ASSOCIAÇÃO BRASILEIRA DE EDITORES DE LIVROS. Estudo radiografa o perfil do professor. As estatísticas dos professores do Brasil. (Inep/MEC). Abrelivros. Associação Brasileira de Editores de Livros. Disponível em http://www.abrelivros.org.br. Acesso em 01/10/2006.

9_ BASTOS, J. R. M.; SALES PERES S. H. C. et al. Odontologia em saúde coletiva: Planejando ações e promovendo saúde.In: PEREIRA, A. C. e cols. 2003. Porto Alegre: Artmed, 2003. p.117-139.

10_ BRASIL PR. Lei n. 9.394, de 20-12-1996. Estabelece as diretrizes e bases da educação nacional. Diário da União. Brasília: Gráfica do Senado. v cxxxiv, n. 248, 23-12-96, pp 27833-27841.

11_ BASTOS, R. C. et al. Declínio da cárie dentária e incremento no percentual de escolares, de 12 anos de idade, livres da doença em Bauru, São Paulo entre 1976 e 1995. Rev Fac Odontol Bauru, Bauru, v. 10, n. 2, p. 75-80, abr./jun. 2002.

12_ BARROS, O. B. de; PERNAMBUCO, R. de A.; TOMITA, N. E. Escovas dentais. PGR: Pós-Grad Rev Fac Odontol, São José dos Campos, São José dos Campos, v. 4, n. 1, p. 32-37, jan./abr. 2001. 
13_ BELTRÃO, E. M. et al. Conhecimento dos pediatras de João Pessoa sobre promoção de saúde bucal. Rev Bras Ciências Saúde, v. 6, n. 2, p.135-146, 2002.

14_ BIJELLA, M. F. T. B., A importância da educação em saúde bucal nos programas preventivos para crianças. J Brás Odontoped Odonto bebê, Curitiba, v. 2, n. 6, p. 127-131, 1999

15_ BÓGUS, C. M.; BiCUdO PEREIRA, I. M. T.; WESTPHAL, M. F. Educação em saúde na escola: como esta a formação de professores de $1^{\mathrm{a}}$ à $4^{\mathrm{a}}$ série do $1^{\mathrm{o}} \mathrm{Grau}$. Rev Bras Saúde Escolar, Rio de Janeiro, v. 1, n. 1, p. 14-17, jan. 1990

16_BOURGET, M. M. M. I. R. O que é saúde $\mathbf{x}$ doença. Programa de Saúde da Família. Manual para o Curso Introdutório. São Paulo: Editora Martinari, 2005. p. 65-70.

17_ CARLOTTO, M. S. Burnout e o trabalho docente: considerações sobre a intervenção. Disponível em http: www.dpi.uem.br.Interaçao. Acesso em 04-10-2006. 
18_ CAMPOS, M. M. A formação de professores para crianças de 0 a 10 anos: modelos em debate. Educação \& Sociedade. Campinas, v. 20, n. 68, p. 1-18, dez. 1999.

19_ CAMPOS, J.A.P.B.; GARCIA, P.P.N.S. Comparação do conhecimento sobre cárie dental e higiene bucal entre professores de escolas de ensino fundamental. Cienc Odontol Bras, v.7.n.1:p.58-65.2004

20_ CARVAlHO, A. C. P.; KRIGER, L. Educação Odontológica. São Paulo: Artes Médicas, 2006. p. 217-223.

21_ CARVALHO, M. M. B. O professor, um profissional, sua saúde e a educação em saúde na escola. Tese (Doutorado). Faculdade de Saúde Pública, Universidade de São Paulo, São Paulo, 1995

22_ CHAVES, M. M. Educação em Odontologia. In Odontologia social, $3^{a}$ ed. São Paulo: Artes Médicas, ano. cap. IX, p. 359-360, 1986.

23_ COSTA, I. C. C.; FUSCELlA, M. A. P., Educação e saúde: importância da integração dessas práticas na simplificação do saber. Ação Coletiva. Brasília, v.2, n.3, p. 45-47, jul./set. 1999.

24_ COSTA, E. I.; SILVA, E. M.; COSTA, I. C. C., Como motivar adolescentes em saúde bucal: avaliação de estratégias didático 
pedagógicas aplicadas em escolas públicas de São Luis; MA. Rev Fac Odontol Lins, Lins, v. 13, n. 2, p. 36-43, jul./dez. 2001.

25_ CORRÊA, M. S. N. P.; DISSENHA, R. M. S.; WEFFORT, S. Y. K. Saúde bucal do bebê ao adolescente: guia de orientação.São Paulo: Ed. Santos - São Paulo, 2005. p. 109-118.

26_ CYRINO, E. G.; PEREIRA M. L. T., Reflexões sobre uma proposta de integração saúde-escola: O projeto saúde e educação de Botucatu. Cad Saúde Pública, São Paulo, v. 15, p. 39-44, 1999. Supplement 2.

27_ DELCOR, N. S. et al. Condições de trabalho e saúde dos professores da rede particular de ensino de Vitória da Conquista, Bahia, Brasil. Cadernos de Saúde Pública. Rio de Janeiro v. 20, n. 1, p , Jan./fev. 2004. Disponível em www.scielo.br/scielo.com.br. Acesso em 10/10/2006.

28_ DIAS, F. A.; BARBOSA, G. B.; PRAIS, M. L. C. F. Papel social da escola na construção de hábitos saudáveis por meio do programa de promoção da saúde bucal. Monografia (Especialização) Associação Brasileira de Odontologia, 2004

29_DRUMOND, M. M. Auto-exame bucal: estratégia metodológica para desenvolvimento da auto-estima e auto cuidado. In: ENCONTRO DE 
EXTENSÃO DA UNIVERSIDADE FEDERAL DE MINAS GERAIS , 7., Belo Horizonte, 2004. Anais. Belo Horizonte, UFMG, 2004.

30_ FERREIRA, J. M. S. et al. Conhecimento de alunos concluintes de pedagogia sobre saúde bucal. Interface-comunicação, saúde, educação, Botucatu, v. 9, n. 17, p. 1-11, mar./ago. 2005. Acesso em 19/07/2006.

31_ FERREIRA, N. F. et al. O que os professores da rede conhecem sobre saúde bucal. In: ENATESPO - ENCONTRO NACIONAL DE ADMINISTRADORES E TÉCNICOS DOS SERVIÇOS PÚBLICOS ODONTOLÓGICOS, XVIII, Salvador, 2005. Anais. Salvador, 2005.

32_ FERRIANE, M. C. et al. Histórico da saúde do escolar: visão global dos serviços de saúde escolar no pais. Rev Bras. Saúde Escolar, Rio de Janeiro, v. 1, n. 3/4, p. 21-27, 1990.

33_ FLORES, O. Educação em saúde ou prática de saúde enquanto prática social. Ação Coletiva: Brasília, v. 2, n. 2, p. 19-24, abr./jun. 1999.

34_ FOCESI, E., Uma nova visão de saúde escolar e educação em saúde na escola. Rev Bras Saúde Escolar, Rio de Janeiro, v. 2, n. 1, p, 1921,1992 
35_ FRAGA, R. C. M. S. et al. Promoção e manutenção de Saúde Bucal, comparação de comportamento quanto a hábito de higiene bucal, entre escolares da rede pública, projetos de extramuros de curso de odontologia da USC-Bauru-SP. Ação Coletiva. Brasilia, v. 2, n. 2, p. 39-43, abr./jun. 1999.

36_ FREIRE, M.C.; SOARES,F.F.; PEREIRA,M.F. Conhecimento sobre saúde dental, dieta e higiene bucal de crianças atendidas pela Faculdade de Odontologia da Universidade Federal de Goiás. JBPJ.Bras Odontol \& Odontol Bebê, Curitiba, v.5, n. 25, p.195-199, 2002.

37_ FREIRE, M. C. M. et al. Prevalência da cárie e necessidade de tratamento em escolares de 6 a 12 anos da rede pública de ensino. Rev Saúde Pública, São Paulo, v. 33, n. 4, p. 385-390, 1999.

38_ FREITAS, B. C. Multiplicadores de saúde: importância da humanização de atendimento à saúde como ação de cidadania. $\mathbf{R e v}$ Bras Odontol Saúde Coletiva. Resumo. XVII Enatespo. Maio. 2002.

39_ GADOTTI, M. Perspectivas atuais da educação. São Paulo Perspec.,São Paulo, v. 14, n. 2, p. 3-11, abr./jun. 2000. Disponível em http://www.scielo.br/pdf/spp/v14n2/9782.pdf . 
40_ GARCIA, P. P. N. S.; CORONA, S. A. M.; VALSECKI JUNIOR, A. Educação e motivação; II. Avaliação da efetividade de métodos educativo-preventivos relativos à cárie dental e à doença periodontal. Rev Odontol UNESP, São Paulo, v. 22, n. 2, p. 405-415, 1998.

41_ GLASRUD, P. H.; FRAZIER, P. J. Future elemntary schooleteacher' s knowledge and opinions about oral health and comunity programs. $\mathbf{J}$ Public Health Dent, Raleagh, v. 48, n. 2, p. 74-80. 1998

42_ GUIDA, M. H.; VASCONCELOS, G. A. N.; VASCONCELOS, A. Odontologia na sala de aula e na comunidade: saúde bucal e prevenção. Teresópolis: Zem Gráfica e Editora, 1994.

43_ GuimarÃes, T. A. A.; MElO, A. A. S.; FernandeS, M. H. A concepção de professores de ensino fundamental do município de Jequié-BA sobre saúde-doença. Revista Saúde.Com, Jequié, BA, v. 1. n. 2: p. 95-99, 2005, Disponível em: http://resb.br/revista/rsc/v1/v1n2a2.pdf . Acesso em 03/09/2006.

44_ HAWKINS, R. J. et al. Oral higiene knowledge of high-risk Grade One children: an evaluation of two methods of dental health education. Community Dent Oral Epidemiol, Copenhagen, v. 28. n. 5, p. 336343, 2000. 
45_ HILGERT, E. C.; ABEGG, C.; PRETTO S. M. Análise das abordagens de educação em saúde em programas de saúde bucal. Ação Coletiva. Brasilia, v. 2. n. 2, p.10-14, abr./jun. 1999.

46_ HILGERT, E. C. Educação em saúde bucal no ensino fundamental em escolas de Porto Alegre. Mestrado - Faculdade Universidade. 2001.

47_ IERVOLINO, S. A. Escola promotora da saúde: Um projeto de qualidade de vida. Dissertação (Mestrado) - Faculdade de Saúde Pública, Universidade de São Paulo, 2000.

48_ KRAMER, P. F. et al. Traumatic dental injuries in Brazilian preschool children. Dent Traumatol, Copenhagen, v. 19, n. 6, p. 299-303, Dec. 2003.

49_ KRIGGER, L., Promoção de saúde bucal: Aboprev. São Paulo: Ed. Artes Médicas, 1997. 475p.

50_ KUNERT, I. R. et al. Motivação em saúde bucal. RGO, Porto Alegre, v. 38 , n. 6 , p. $450-456$, nov./dez. 1990

51_ LANG, P.; WOOLFOLK, M. V.; FAJA, B. W. Oral health knowledge and attitudes of elementary schoolteachers in Michigan. J Public Health Dent, Raleigh,v. 49, n. 1, p. 44-50, Winter. 1989. 
52_ LEAL, G. P. Formação de professores. Disponível em: http://www.reescrevendoaeducacao.com.br. Acesso em 01/10/2006.

53_ LEFEVRE, F.; LEFEVRE,A.M.C. Recuperando a fala do social. Série monográfica n.9, Universidade de São Paulo. Faculdade de Saúde Publica, 1989. In: SILVEIRA, 2000.

54_ LEONELLO, V. L.; L’ABBATE, S. Educação em saúde na escola: uma abordagem do currículo e da percepção de alunos de graduação em Pedagogia. Interface-Comunic Saúde Educ. Botucatu, v. 10, n.19, p. 149-166. jan./jun. 2006. Disponível em: http://www.scielo.br/pdf/cse/v10n19/a11f1019.pdf . Acesso em 24/10/2006.

55_ LEVINE, R. The scientific bases of dental health education. 4 ed. London, Health Educacion Autority,1996, In : Hilgert. 2001.

56_ LOUREIRO, C. F. B. A problemática de saúde da criança no Brasil: desafio para prática educativa. Rev Bras Saúde Escolar, São Paulo, v. 4 , n. $1 / 2$, p. 17-20, 1996.

57_ MACEDO, A. F. et al. Saúde bucal no Marajó. 2006. Disponível em Educação em Saúde na Escola. Acesso em 15/08/2006. 
MACEDO, N. L.; LACAZ NETTO, R. Manual de higienização bucal: motivação dos pacientes. 3. Ed. São Paulo: publicações Médicas, 1986.

59_ MAIA, D; ROCHA, S. Os programas saúde da família e agente comunitários de saúde e sua interface com a escola. Salto, 2002. Disponível em http://tvebrasil.com.br/salto/boletim/2002.

60_ MALTZ, M; SILVA, B. B. Relação entre cárie, gengivite e fluorose e nível socioeconômico em escolas. Rev Saúde Pública, São Paulo, v. 35, n. 2, p. 170-176. 2001.

61_ MANUAL para operacionalização das ações educativas no SUS - São Paulo: Centro de Vigilância Epidemiológica da Secretaria de Estado de Saúde de São Paulo, 1997.

62_ MARTINEZ, A. M. La escuela: um espacio de promocion de salud. Psicologia escolar e educacional. v. 1, n. 1, p. 19-24. 1996.

63_ MARTINS, E. M. Construindo o valor de saúde bucal. Ação Coletiva, Brasília, v. 2, n. 2, p. 5-9. abr./jun. 1999.

64_ MEDEIROS, M. I. D., et al. Conhecimentos e atitudes de professores de Ensino Fundamental sobre saúde bucal: um estudo qualitativo. 
Pesq Brás Odontop Clin Integr, v. 4, n. 2, p. 131-136, maio/ago. 2004.

65_ MELO, E. H.; FREIRE, E. J.; BASTOS, H. F. B. Ensino-aprendizagem de conceitos científicos em saúde bucal nas séries iniciais do ensino fundamental à luz da análise da conversação. Revista Letra Magna, São Paulo, v. 2, n. 2, p. 1-17, 2005.

66_ MINISTÉRIO DA EDUCAÇÃO E DO DESPORTO. Secretaria do Ensino Fundamental. Fundo de manutenção e desenvolvimento do ensino fundamental e de valorização do magistério- Manual de orientação, $\quad$ 1998. Disponível em http://www.mec.gov.br/sef/fundh/defaut/shtm.

67_ MINISTÉRIO DA EDUCAÇÃO. Secretaria da Educação Fundamental. Parâmetros curriculares nacionais: primeiro e segundo ciclos. Brasília (DF): MEC SEF; 1997.

68_ MINISTÉRIO DA EDUCAÇÃO. Secretaria da Educação Fundamental. Parâmetros Curriculares Nacionais: apresentação dos temas transversal e Ética. Brasília, 1997 (e)

69_ MOIMAZ, S.A.S. Saúde bucal e a professora de primeiro grau. RGO, Porto Alegre, v. 40, n. 4, p. 295-297. jul./ago. 1992. 
70_ MORAIS, P. Educação para Saúde, treinamento de professores, aulas sobre saúde bucal para crianças da pré-escola à $4^{\mathrm{a}}$ sèrie do $1^{\circ} \mathrm{Grau:}$ Algumas experiências. Ação Coletiva, Brasília, v.2,n.2; abr/jun,p.4446.1999.

71_ MWANGOSI, I. E. A. T. Oral health related knowledge, behaviours, attitude and self-assessed status of primary school teachers in Tanzânia. Int Dent J, London, v. 52, n. 3, p. 130-136, June. 2002.

72_ OlIVEIRA, C. B. E.; ALVES, P. B., Ensino fundamental: papel do professor, motivação e estimulação no contexto escolar. Paidéia: cadernos de psicologia e educação, Ribeirão Preto, v. 15, n. 31, p. 227-238, 2005.

73_ PACHECO, L. F. et al. Evaluation of the knowledge of the treatment of avulsions in elementary school teachers in Rio de Janeiro, Brazil. Dent Traumatol, Copenhagen, v. 19, p. 76-78. 2003.

74_ PANZERI, H. et al. Avaliação de algumas características das escovas dentais do mercado nacional. Rev Ass Bras Odontol, v. 1, n. 1, p.2329, Jul/Set. 1993.

75_ PAUletO, A. C.; PEREIRA, M. L. T.; CYRINO, E. G. Saúde bucal: uma revisão crítica sobre programações educativas para escolares. 
Ciências \& Saúde Coletiva, Rio de Janeiro, v. 9, n. 1, p. 121-130, 2004.

76_ PELLICIONI E TORRES, 1999. A escola promotora da Saúde. São Paulo: FSP-USP(1999). (Série Monografia do Departamento de Prática de Saúde Pública - Eixo de Promoção de Saúde,12).

77_ PENTEADO, R. Z.; BICUDO, PEREIRA I. M. T. Integração e educação em saúde: novas possibilidades para o modelo de saúde bucal nas escolas. Rev Bras Saúde Escolar, São Paulo, v. 4, n. 4, p. 23-31, 1996.

78_ PEREIRA, A. C. et al. Odontologia em saúde coletiva: planejando ações e promovendo saúde. Porto Alegre: Ed. Artmed, 2003, p. 117139.

79_ PETERSEN, O. E.; ESHENG, Z. Dental cáries and oral health behaviour situation of children, mothers and schoolteachers in Wuhan, people's Republic of China. Int Dent J, London, v. 48, n. 3, p. 210-216, June, 1998.

80_ PETRY, P. C.; PRETTO, S. M. Educação e motivação em saúde bucal. In: Aboprev, São Paulo: Artes Médicas, 1997. p. 363-370. 
81_ PILON, A. F. Qualidade de vida e formas de relacionamento homemmundo. Rev Bras Saúde Escolar, São Paulo, v. 2, n. , p. 117-125, 1995.

82_ PINTO, E. D. R.; PAIVA, E. M. M.; PIMENTA, F. C. Viabilidade de microorganismos anaeróbicos da cavidade bucal em escovas dentárias. Periodontia, Rio de Janeiro, v. 6, n. 1, p. 8-12, jan./jun. 1997.

83_ PINTO, V. G., Saúde bucal coletiva. 4. ed. São Paulo, 2000.Santos. São Paulo.

84_ POMARICO, L. et al. Higiene bucal no ambiente escolar:avaliação de professoras. JBP. J Bras Odontopediatr odontol Bebe, Curitiba, v. 3, n. 14, p. 295-299, 2000.

85_ RAMIRES, I. ET AL. Avaliação da concentração de flúor e do consumo de água mineral. Rev Saúde Pública, São Paulo, v. 38, n.; 3, p. 459-465, jun. 2004.

86_ RAMOS, S. B.; BICUDO PEREIRA, I.M.T. A saúde escolar no novo modelo de atenção à saúde:uma visão educativa. Rev Bras Saúde Escolar, Rio de Janeiro, v.1,p.9-10,1990, In: CARVALHO,1995. 
87_ RAYNER, J. A., Dental health education program, including home visits, for nurses school children. Brit Dent J, London, v. 172, n. 2, p. 57-62, Jan. 1992.

88_ RIZZO, R. Uma utilização sobre a utilização dos recursos tecnológicos e dos meios de comunicação em saúde coletiva: baseada na experiência da escola de saúde publica do Paraná. Ação Coletiva, Brasília, v. 2, n. 2, p. 33-38, abr./jun. 1999.

89_ ROBERTSON, A.; NORÉN, J.G. Knowlefge-based system for strutured examination, diagnosis and therapy in treatment of traumatised teeth. Dent. Traumatol, Copenhagen, v. 17: p.5-9, 2002.

90_ ROSSI, V. L. S. Desafio à escola pública: tomar em suas mãos o seu próprio destino. Caderno Cedes. Nov./2001. p- 92-107.

91_ SANT'ANNA, R. M. F. et al. Prevalência da cárie dentária no hebiatra (adolescente), residente em Bauru-SP no ano de 2004. In : REUNIÃO ANUAL DA SOCIEDADE BRASILEIRA DE PESQUISA ODONTOLÓGICA - SBPqo. 22ª́ , Águas de Lindóia, 2005.

92_ SANTOS, P. A. Avaliação do conhecimento dos professores do ensino fundamental de escolas particulares sobre saúde bucal. Rev Odontol UNESP, São Paulo, v. 31, n. 2, p. 205-214, 2002. 
93_ SANTOS, P. A.; RODRIGUES, J. A.; GARCIA, P. P. N. S. Conhecimentos sobre prevenção de cárie e doença periodontal e comportamento de higiene bucal de professores de ensino fundamental. Ciênc Odontol Brás, v. 6, n. 1, p. 67-74. jan./mar. 2003.

94_ SANTOS, T. C. P. M.; ULIANE, C. S. Profissionalização docente: ser professor nos dias de hoje. Pedagogo Brasil: o futuro do planeta em suas mãos. Disponível em http: //www.pedagobrasil.com.br/pedagogia/profissionalizaçãodocente. htm. Acesso em 09/09/2006.

95_ SGAN-COHEN, H. D.; SAADI, S.; WEISSMAN, A., Dental knowledge and attitudes among Arab schoolteachers in northern Israel. Int Dent J, London, v. 49, n. 5, p. 269-274, Oct. 1999.

96_ SHEIHAM, A. Mudança necessária na política de saúde bucal brasileira: "o pulo do gato". Jornal do site Odonto. V. 3, n. 45, nov. 2001. Disponível em: http://www.jornaldosite.com.br/arquivo/anteriores/aubrey/artabrey46.ht m. Acesso em 19/07/2006.

97_ SKAARE, A. B.; JACOBSEN, I. Etiological factors related to dental injuries in Norwegians aged 7-18 years. Dent Traumatol, Copenhagen, v. 19, n. 6, p. 304-308, Dec. 2003. 
98_ SILVA, A. L. T. A saúde bucal coletiva sob a ótica de professores da rede estadual de ensino de São Paulo. São Paulo, 2002. Dissertação (Mestrado) - Faculdade de Saúde Pública, Universidade de São Paulo.

99_SILVEIRA, E. G.; SILVA, R. H. H.; ALMEIDA, I. C. S., Uma metodologia para um programa educativo em saúde bucal para escolares. Rev Paul Odont, São Paulo,v. 20, n. 1, p. 8-16, jan./fev. 1998.

100_ SILVEIRA, G. T. Escola promotora de saúde: quem sabe faz a hora! São Paulo, 2000. Tese (Doutorado) - Faculdade de Saúde Pública, Universidade de São Paulo.

101_ TEMPORINI, E. R. Percepção de professores do sistema de ensino de estado de São Paulo sobre seu preparo em saúde do escolar. Rev Saúde Pública, São Paulo, v. 22, n. 5, p. 411-421, 1988.

102_ TOMITA, N. E. et al. Educação em saúde bucal para adolescentes: uso de métodos participativos. Rev FOB, Bauru, v. 9, n. 1/2. p. 63-69, jan./jun. 2001. 
103_ TRAEBERT, J. L., et al. Prevalência e severidade da cárie dentária em escolares de seis e doze anos de idade. Rev Saúde Pública, São Paulo, v. 35, n. 3, p. 238-283, jun. 2001.

104_ TROPE, M. Clinical management of the avulsed tooth: present strategies anf future directons. Dent Traumatol, Copenhagen, v. 18, n. 1, p. 1-11, Feb. 2002.

105_ TUMENAS, I. Escovas dentais: orientando o paciente. Rev Assoc Paul Cirur Dent, São Paulo, v. 53, n. 4, p.307, Jul/Ago. 1999.

106_ Unesco - Brasil. A educação infantil. O mundo precisa de professores mais bem qualificados. Disponível em: http:www.unesco.org.br.áreas.educação. Acesso em 01/10/2006.

107_ UNFER, B.; SALIBA, O. Avaliação do conhecimento popular e práticas cotidianas em saúde bucal. Rev Saúde Pública, São Paulo, v. 34, n. 2, p. 190-195, 2000.

108_ VALADÃO, M. M., Saúde na escola: um campo em busca do espaço na agenda intersetorial. Tese (Doutorado) - Faculdade de Saúde Pública, Universidade de São Paulo, São Paulo, 2004. 
109_ VASCONCELOS, A.; VASCONCELOS, G. A. N., Cidadania: exclusão e saúde bucal. Ação Coletiva, Brasília, v. 2, n. , p. 29-32, abr./jun. 1999.

110_ VASCONCELOS, R. et al. Escola: um espaço importante em saúde bucal para a população infantil. Rev Fac Odontol, São José dos Campos, v. 4, n. 3, p. 43-48, set./dez. 2001.

111_ VELLOZO, R. C. A. D. M. et al. Professor: agente socializador de conhecimento e saúde bucal. In: REUNIÃO ANUAL DA SOCIEDADE BRASILEIRA DE PESQUISA ODONTOLÓGICA - SBPqo, 22ª., Águas de Lindóia, 2005.

112_ VOLSCHAM, B. C. G., SOARES, E. L., Educação em saúde. Revista Aboprev, v. 5, n. 2, p. 27-32, jul./dez, 2002. 


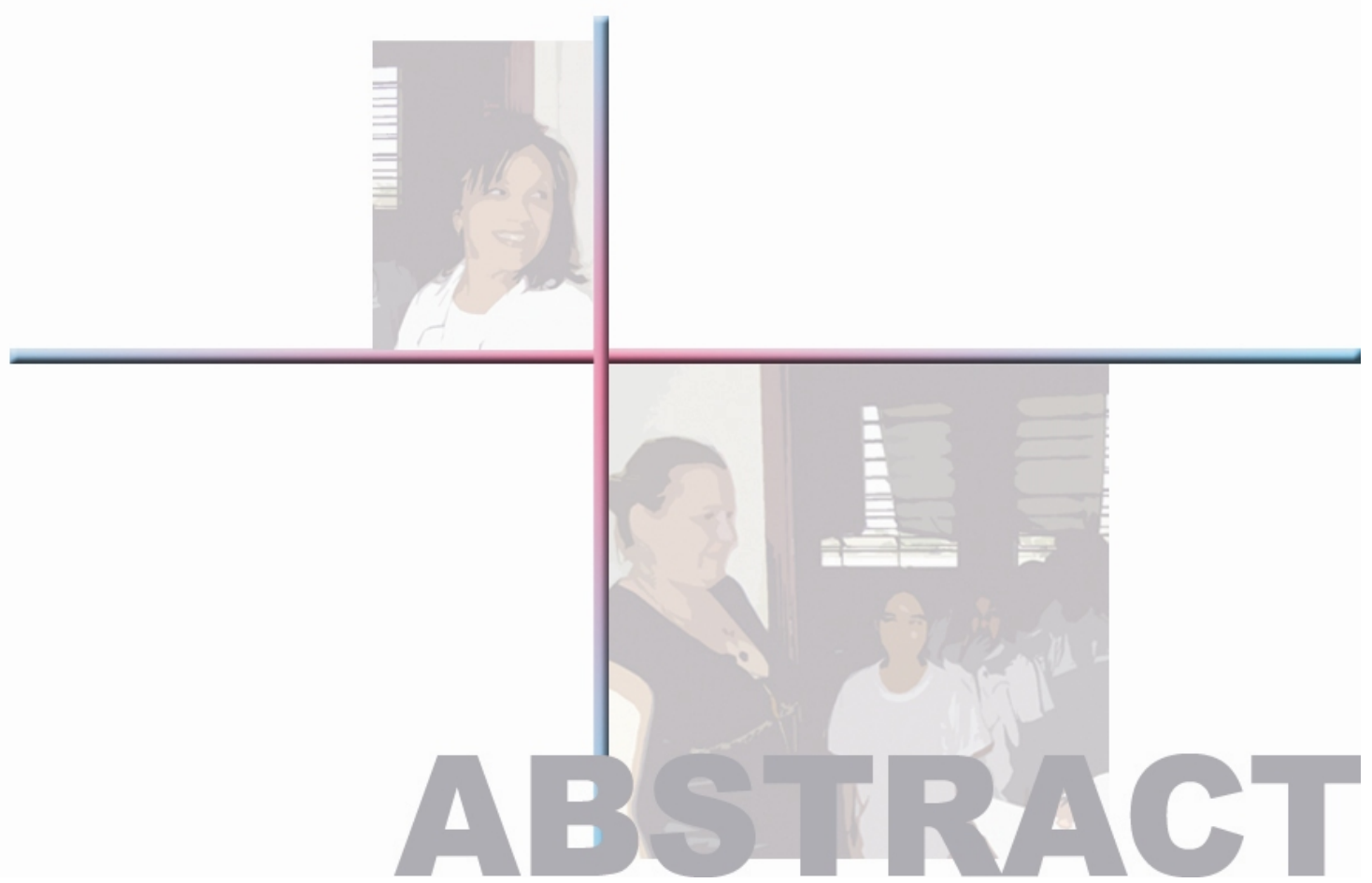

ABSTRACT 
Analysis of the oral health knowledge of teachers of public schools at Bauru-SP

\section{ABSTRACT}

Teachers at public schools are references of information on oral health for their students, either due to their responsibility to provide information on health and because of their regular contact with children, opportunity to address questions on the prevention of oral diseases by their attitudes and teaching, and in the establishment of general health concepts in schoolchildren.

The general objective of this study was to analyze the oral health knowledge of teachers of public fundamental schools at the city of Bauru, SP. The specific objective was to investigate the attitude of these professionals in relation to health education and oral health promotion in the classroom. Individual interviews were performed by application of a semistructure questionnaire containing 20 open and closed questions to 307 teachers at 24 state and municipal schools.

The following results were highlighted in the present study: $92.5 \%$ of interviewees mentioned the importance of oral health for the children; $36.0 \%$ received training in oral health; $48.0 \%$ indicated caries prevention as a function of fluoride; on the other hand, $10.7 \%$ were unaware of the sources of access to fluoride; $38 \%$ did not know periodontal disease; and $23 \%$ 
answered that they are unable to provide first aid in case of dental trauma.

It was concluded that the teachers interviewed have some oral health knowledge, even though they did not have any information on some important aspects. It is important to reinforce the scientific knowledge by educational and preventive practices targeted to oral health in schools, since these are often the only sources providing daily information to students in public schools.

Keywords: Health education, dental. School health. Health education. Oral health. Health knowledge, attitudes, practice. 

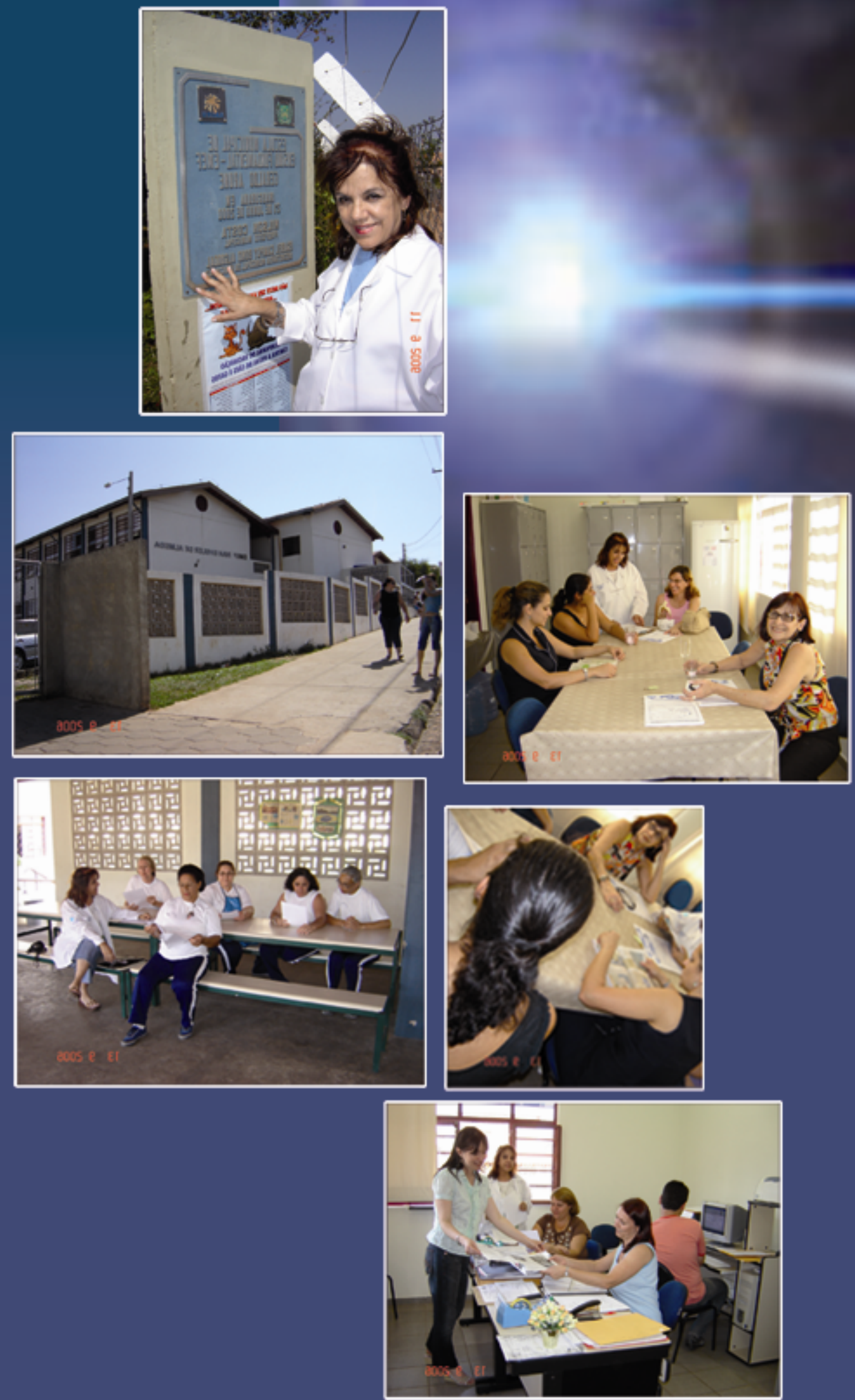

0 professor faz fluir o saber construindo sentido para a vida das pessoas e para a humanidade e buscam, juntos, um mundo mais justo, mais produtivo, mais saudável para todos. Por tudo isso eles são imprescindiveis. 